\author{
UNIVERSIDADE DE SÃO PAULO \\ FACULdADE DE OdONTOLOGIA DE RIBEIRÃO PRETO \\ DEPARTAMENTO DE CLÍNICA INFANTIL \\ Programa de PÓS-Graduação em OdOntopediatRia
}

\title{
Diabetes Mellitus Altera a Sinalização Osteogênica e Atrasa o Processo Reparo Ósseo após Expansão RÁPIDA da MAXILA
}

\author{
MaYa Fernanda MANFrin ARnez
}

RIBEIRÃo PRETO 
Maya Fernanda MANFrin ARnez

Diabetes Mellitus Altera a Sinalização Osteogênica e Atrasa o Processo de Reparo ÓsSeo após Expansão RÁPIDA dA MAXILA

Tese apresentada à Faculdade de Odontologia de Ribeirão Preto da Universidade de São Paulo, para obtenção do Título de Doutora em Ciências.

Área de concentração: Odontopediatria

Orientadora: Profa. Dra. Maria Bemadete Sasso Stuani

RIBEIRÃo PRETO

2014 
AUTORIZO A REPRODUÇÃO E DIVULGAÇÃO TOTAL OU PARCIAL DESTE TRABALHO, POR QUALQUER MEIO CONVENCIONAL OU ELETRÔNICO, PARA FINS DE ESTUDO E PESQUISA, DESDE QUE CITADA A FONTE.

Arnez, Maya Fernanda Manfrin

Diabetes mellitus altera a sinalização osteogênica e atrasa o processo de reparo ósseo após expansão rápida da maxila, 2014.

126 p. : il. ; $30 \mathrm{~cm}$

Tese de Doutorado, apresentada à Faculdade de Odontologia de Ribeirão Preto da Universidade de São Paulo. Área de concentração: Odontopediatria.

Orientadora: Stuani, Maria Bernadete Sasso.

1. Estreptozotocina. 2. Diabetes mellitus tipo 1. 3. Expansão rápida da maxila.

4. Remodelação óssea. 5. Reparo ósseo 
FOLHA DE APROVAÇÃo

Arnez, MFM. Diabetes mellitus altera a sinalização osteogênica e atrasa o processo de reparo ósseo após expansão rápida da maxila. Tese apresentada à Faculdade de Odontologia de Ribeirão Preto da Universidade de São Paulo, para obtenção do Título de Doutora em Ciências. Área de Concentração: Odontopediatria.

Data da defesa: $\ldots / \ldots$

\section{Banca Examinadora}

Prof. Dr.

Instituição:

Julgamento: Assinatura:

Prof. Dr.

Instituição:

Julgamento: Assinatura:

Prof. Dr.

Instituição:

Julgamento: Assinatura:

Prof. Dr.

Instituição:

Julgamento: Assinatura:

Prof. Dr.

Instituição:

Julgamento: Assinatura: 


\section{MAYA FERnANDA MANFRIn ARneZ}

Nascimento: $\quad 06$ de fevereiro de 1980, Ribeirão Preto, SP

Filiação: $\quad$ Marlene Aparecida Manfrin Arnez

Gonzalo Fernando Arnez Taboada

2000-2003 Graduação em Odontologia

Faculdade de Odontologia de Ribeirão Preto da Universidade de São Paulo

Iniciação Científica: Os efeitos do ambiente enriquecido sobre a recuperação de ratos que sofreram lesão do nervo facial.

Orientadora: Profa. Dra. Elaine Aparecida Del Bel Beluz Guimarães

Bolsa: PIBIC/USP/CNP

2004-2006 Curso de Especialização em Cirurgia e Traumatologia BucoMaxilo-Facial

Departamento de Cirurgia e Traumatologia Buco-Maxilo-Facial da Faculdade de Odontologia de Ribeirão Preto da Universidade de São Paulo.

2006-2009 Mestrado em Cirurgia Buco-Maxilo-Facial

Faculdade de Odontologia de Ribeirão Preto da Universidade de São Paulo

Dissertação: Osseointegração de implantes em defeitos circunferenciais utilizando proteínas angiogênicas purificadas do látex, osso autógeno e regeneração óssea guiada. Estudo comparativo em mandíbulas de cães.

Orientador: Prof. Dr. Luiz Antônio Salata

Bolsa: FAPESP

2010-2014 Doutorado em Ciências

Faculdade de Odontologia de Ribeirão Preto da Universidade de São Paulo

Tese: Diabetes mellitus altera a sinalização osteogênica e atrasa o processo de reparo ósseo após expansão rápida da maxila. Orientadora: Profa. Dra. Maria Bernadete Sasso Stuani Bolsa: FAPESP 


\section{DEDICO ESTE TRABALHO}

\section{Aos meus pais Gonzalo Fernando Arnez Taboada e Marlene Aparecida Manfrin Arnez.}

Vocês são meus verdadeiros heróis, exemplos de postura, profissionalismo, humanidade e amor. Pessoas em quem me espelho todos os dias. Obrigada pelos incentivos, apoio incondicional em todos os momentos da minha vida, pela dedicação, carinho e pelos esforços para que minha educação fosse a melhor possivel. Por compreenderem os motivos da minha constante ausência e por estarem sempre presentes. Serei eternamente grata.

Aos meus irmãos Marck Fernando Manfrin Arnez e Mayara Manfrin Arnez, por toda força, ajuda, amizade e compreensão. Por transformarem momentos simples em grandes lembranças inesquecíveis e por tornarem esta caminhada mais fácil, divertida e prazerosa. Sem vocês a vida seria muito mais sem graça. Muito obrigada por fazerem parte de tudo!

Ao meu marido Francisco Wanderley Garcia de Paula e Silva, pelo carinho, paciência, companheirismo e apoio constante. Por compartilhar sua experiência comigo e sempre me ensinar. Por acreditar em mim, por me apoiar, me confortar nos momentos dificeis e não me deixar desistir nunca. Obrigada por tornar simples o que muitas vezes parecia complicado, por dividir todos os momentos de alegria, me incentivar na busca de vitórias e na realização dos meus sonhos. Admiro sua postura, dedicação e inteligência. Você é a parte que me falta e me completa. Pessoas especiais como você são colocadas na nossa vida para nos mostrar uma direção e fazer a diferença. Meu muito obrigada de coração!!!

Ao Francisco Wanderley de Paula e Silva, Maria Angélica Garcia de Paula e Silva e Livia

Cristina Arcipreti de Paula e Silva. Pelo apoio constante. Obrigada pela acolhida calorosa, animada e por compartilharem comigo momentos inesquecíveis.

Ao Felipe Posses Moys e Tatiane Rocco Dias. Pelas palavras de incentivo, confiança e pelos momentos de descontração. Foi um privilégio compartilhar meu tempo com vocês.

À Domingas Ilma de Araújo Barros pelo apoio, compreensão e por tornar as minhas visitas na casa da minha família ainda mais saborosas. 


\section{AGRADECIMENTOS ESPECIAIS}

\section{À Profa. Dra. Maria Bernadete Sasso Stuani pela experiência}

compartilhada e orientação segura no desenvolvimento deste trabalho. Obrigado por acreditar na minha capacidade e abrir novos caminhos para a minha formação intelectual e científica. Agradeço por ter me recebido como aluna, pelos ensinamentos, por guiar meus passos na Odontologia e por mostrar que é possível associar carinho, amizade, humanidade, competência e profissionalismo. Fico muito feliz por fazer parte da sua equipe, porque trabalhar com você me fez aprender o que é fazer parte de um time completo e unido!

Ao Prof. Dr. Paulo Nelson Filho e à Profa. Dra. Léa Assed Bezerra da Silva, pelos incentivos constantes à pesquisa e pela dedicação ao ensino, fundamentais para formação docente. Jamais me esquecerei das aulas de Odontopediatria.

\section{Às Profa. Dra. Alexandra Mussolino de Queiroze Kranya Victoria}

Díaz Serrano, pela forma amiga e incentivadora que sempre me receberam em todos os momentos. Obrigada pela amizade e confiança em mim depositadas.

À Profa Dra. Maria Cristina Borsato pela atenção, amizade, conselhos, dedicação e disponibilidade durante as minhas sessões de acupuntura. Sem dúvida, este tratamento fez grande diferença para mim em diversos momentos. 
MEUs AGRADECIMENTOS

À Faculdade de Odontologia de Ribeirão Preto da Universidade de São Paulo, na pessoa do atual Diretor Prof. Dr. Valemar Mallet da Rocha Barros e da Vice-Diretora Profa. Dra. Léa Assed Bezerra da Silva.

À Coordenação do Curso de Pós-Graduação da Faculdade de Odontologia de Ribeirão Preto da Universidade de São Paulo, na pessoa do Prof. Dr. Arthur Belém Novaes Júnior.

Aos demais Professores do Departamento de Clínica Infantil da Faculdade de Odontologia de Ribeirão Preto da Universidade de São Paulo, Profa. Dra. Raquel Assed Bezerra Segato, Profa. Dra. Andiara De Rossi Daldegan, Profa. Dra. Aldevina Campos Freitas, Profa. Dra. Sada Assed, Mirian Aiko Nakane Matsumoto, Fábio Lourenço Romano, José Tarcísio Lima Ferreira, Adĩlson Tomasine Maria da Conceição Pereira Saraiva aos Professores do Departamento de Morfologia, Estomatologia e Fisiologia da Faculdade de Odontologia de Ribeirão Preto da Universidade de São Paulo Profa. Dra. Mamie Mizusaki lyomasa e Prof. Dr. João Paulo Madergan Issa e às Professoras do Departamento de Análises Clínicas, Toxicológicas e Bromatológicas da Faculdade de Ciências Farmacêuticas de Ribeirão Preto da Universidade de São Paulo Profa. Dra. Lúcia Helena Faccioli e Profa. Dra. Fabiane Gai Frantz.

À Elaine Machado Pingueiro Okada, a "Maria", pelo carinho, amizade, ajuda, apoio, dedicação, disponibilidade e colaboração durante este doutorado. Por sempre mostrar como ter respeito e carinho pelos animais de laboratório. Obrigada por me ensinar tudo o que você sabe e ser minha amiga em todos os momentos. Sem você com certeza esta caminhada não teria o mesmo encanto! Espero que algum dia eu consiga retribuir toda a ajuda que recebi.

Ao Gabriel Barretto Dessotti e Kelly Galisteu Luiz pela cooperação, colaboração e dedicação durante a realização desta pesquisa. Obrigada pelas boas risadas, conversas, ensinamentos culinários e por fazerem parte desta caminhada, que com certeza com vocês ficou muito mais agradável e saborosa! 
À Larissa Nogueira Soares Ribeiro pela disponibilidade, pelos auxîlios durante as fases experimentais desta pesquisa e pela convivência agradável.

À Yamba Carla Lara Pereira e Daniela Mizusaki lyomasa pela ajuda durante a fase histológica deste trabalho. Obrigada pela amizade, pelas boas conversas e conselhos durante este doutorado. Estes momentos foram muito especiais para mim!

À Ana Zilda Nazar Bergamo, Fernanda Regina Ribeiro Santos, Késsia Suênia Fidelis de Mesquita, Marilia Pacífico Lucisano, Patrícia Maria Monteiro e Paula Regina Avila Silvano pelos conselhos, pelas conversas descontraídas, convivência agradável e por tornarem estes momentos especiais. Vocês fizeram diferença neste meu curso de doutorado!

Aos demais pós-graduandos do Programa de Pós-Graduação em Odontopediatria pelas conversas e convivência agradável.

Aos alunos do Laboratório de Morfologia da Faculdade de Odontologia de Ribeirão Preto da Universidade de São Paulo e aos alunos do Laboratório de Inflamação e Imunologia das Parasitoses da Faculdade de Ciências Farmacêuticas de Ribeirão Preto da Universidade de São Paulo. Obrigada pela amizade, companheirismo e suporte durante toda a fase experimental desta pesquisa.

À funcionária do Laboratório de Morfologia da Faculdade de Odontologia de Ribeirão Preto da Universidade de São Paulo, Nilce de Oliveira Wolga pelas grandes histórias, ensinamentos e toda ajuda e disponibilidade na realização do processamento histológico.

Aos funcionários do Laboratório de Inflamação e Imunologia das Parasitoses da Faculdade de Ciências Farmacêuticas de Ribeirão Preto da Universidade de São Paulo Dr. Carlos Arterio Sorgi, Alyne Fávaro Galvão, Caroline Fontanari e Aline de Sousa Soares. Obrigada pelas conversas, ajudas e ensinamentos durante a execução desta pesquisa.

À Michelli Cristina Leite Rovanholo e Filomena Leli Placciti pela amizade, ajuda constante, conselhos, paciência e descontração!!! Muito obrigada por estarem sempre presente nesta minha caminhada! 
Aos funcionários do Departamento de Clínica Infantil da Faculdade de Odontologia de Ribeirão Preto da Universidade de São Paulo, Fătima Aparecida Jacinto Daniel, Matheus Morelli Zanela, Nilza Letícia Magalhães, Marco Antônio dos Santos e Sr. Carmo Eurípedes Terra Barretto e aos funcionários do Centro de Formação de Recursos Humanos no Atendimento Odontológico a Pacientes Especiais Carolina Paes Torres Mantovani, Fătima Aparecida Rizoli e Benedita Viana Rodrigues pela amizade e atenção que sempre manifestaram!

Aos funcionários do Biotério da Faculdade de Odontologia de Ribeirão Preto da Universidade de São Paulo, Aline Aparecida Ferraresi Tiballi, Antonio Sérgio Aparecido Mesca e Antônio Masssaro pela amizade, boa convivência, ajuda, disponibilidade e pelos cuidados prestados aos animais durante todo o período experimental desta pesquisa. Vocês foram muito importantes para o andamento desta minha pesquisa!

Às funcionárias da Seção de Pós-Graduação da Faculdade de Odontologia de Ribeirão Preto da Universidade de São Paulo, Isabel Cristina Galino Sola e Regiane Cristina Moi Sacilotto pela cordialidade e atenção.

Ao Júlio César de Matos è Clăudia Regina Corrêa de Matos, pelo profissionalismo e atenção durante a diagramação e impressão deste trabalho.

À FAPESP (Fundação de Amparo à Pesquisa do Estado de São Paulo), pelo suporte técnico, científico e financeiro fundamentais para a realização deste trabalho. 


\section{RESUMO}

Arnez MFM. Diabetes mellitus altera a sinalização osteogênica e atrasa o processo de reparo ósseo após expansão rápida da maxila [Tese]. Ribeirão Preto: Faculdade de Odontologia de Ribeirão Preto da Universidade de São Paulo; 2014.

Introdução: O diabetes mellitus (DM) é uma doença crônica caracterizada pela hiperglicemia associada a diversas alterações sistêmicas e uma das suas complicações é o processo de reparo ósseo comprometido. Entretanto, ainda não há estudos utilizando análises celulares e biomoleculares que avaliem o processo de reparo ósseo desta desordem metabólica quando associada à expansão rápida da maxila (ERM). Objetivo: $O$ objetivo deste estudo foi avaliar a remodelação óssea e sinalização osteogênica durante a aplicação de mecânica ortodôntica para ERM em ratos diabéticos tipo1induzidos. Material e Métodos: Cento e cinquenta ratos Wistar, machos, foram divididos aleatoriamente em seis grupos de estudo. Grupos: controle $(C, n=30)$, veículo $(V, n=15)$, diabetes mellitus tipo 1 induzido com estreptozotocina $(D, n=30)$, controle submetido à $E R M(C d, n=30)$, veículo submetido à ERM $(\mathrm{Vd}, \mathrm{n}=15)$ e diabetes mellitus tipo 1 induzido com estreptozotocina submetido à ERM ( $\mathrm{Dd}, \mathrm{n}=30)$. Os animais foram eutanasiados aos 3, 7 e 10 dias após ERM. Análises histológicas, mudanças no padrão de expressão gênica e proteica de osteoprotegerina, (OPG), RANK, RANKL, osteonectina (ONC), osteocalcina (OCC), sialoproteína óssea (BSP), osteopontina (OPN) e proteína morfogenética óssea 2 (BMP2), assim como as mudanças no peso corporal, na ingestão de água na glicemia foram avaliadas. A análise da expressão gênica e proteica foram realizadas por qRT-PCR e Western Blotting, respectivamente. Os dados foram submetidos ao teste estatístico ANOVA de duas vias e pós-teste de Tukey $(\alpha=0,05)$. Resultados: Histologicamente no grupo Dd foi notado maior reabsorção óssea, com diversas áreas em degradação com ausência de osteoblastos, intensa atividade de reabsorção óssea solapante, presença de osteoclastos, células inflamatórias associada ao comprometimento da formação óssea quando comparado aos grupos $\mathrm{D}$ e Cd. Estes resultados foram confirmados também nos achados moleculares, uma vez que algumas sinalização gênicas e proteicas relacionadas a osteogênese foram reduzidas, ao passo que a sinalização osteoclastogênica foi estimulada, principalmente no período inicial de reparo ósseo. No grupo $D$, o processo de formação ósseo estava atrasado comparado ao grupo $\mathrm{C}$, devido a alteração da expressão dos genes e proteínas que regulam o catabolismo e anabolismo ósseo, haja vista que havia maior presença de tecido ósseo imaturo e maior quantidade de áreas de remodelação ativa até o período mais tardio de estudo. No grupo Cd foi observado remodelação óssea, caracterizada por um tecido desorganizado na região da sutura palatina mediana, com intensas áreas inflamatórias, hemorrágicas e reabsortivas comparado ao grupo C. Contudo, até o período de 10 dias pós abertura da sutura, não foi possível observar o completo preenchimento do gap sutural por tecido ósseo. Estes resultados histológicos foram observados na sinalização de genes e proteínas no grupo $\mathrm{Cd}$, uma vez que estes biomarcadores de formação e reabsorção óssea estavam alterados quando comparados aos grupos $\mathrm{C}$ e Dd. Conclusões: $\mathrm{O} D \mathrm{DM}$ alterou a sinalização para o metabolismo ósseo e atrasou o processo de reparo após ERM. Estes resultados reforçam a necessidade de avaliar o status do metabolismo ósseo dos pacientes durante tratamento ortopédico e/ ou ortodôntico, visto que a aplicação destas forças na presença do DM podem promover efeitos indesejáveis.

Palavras-chave: estreptozotocina, diabetes mellitus tipo 1, expansão rápida da maxila, remodelação óssea, reparo ósseo. 


\begin{abstract}
Arnez MFM. Diabetes Mellitus modify the osteogenesis signaling and compromise bone repair after rapid maxillary expansion [Thesis]. Ribeirão Preto: School of Dentistry of Ribeirão Preto at University of São Paulo; 2014.

Background: Diabetes mellitus (DM) is a disease associated with several disorders of health in humans and one of the most important is the jeopardizing of bone formation. However, to the best of our knowledge there is no information about the influence of diabetes on orthodontic and orthopedic treatment at cellular and molecular levels. Objective: The aim of this study was to evaluate bone remodeling process in palatal suture during orthopedic mecanotherapy in rats with type 1-induced diabetes mellitus. Material and Methods: One hundred and fifty Wistar male rats were randomly assigned to six groups. Groups: control $(C, n=30)$, vehicle $(B, n=15)$, type 1-induced diabetes mellitus using streptozotocin $(D, n=30)$, control with RME $(C+R M E, n=30)$, vehicle with RME (C+RME, $n=15)$ and type 1-induced diabetes mellitus using streptozotocin with RME ( $+R M E, n=30)$. The animals were euthanized at 3, 7 and 10 days after RME. Histologic evaluations, changes in genes and proteins expression of osteoprotegerin (OPG), RANK, RANKL, osteonectin (ONC), osteocalcin (OCC), bone sialoprotein (BSP), osteopontin (OPN) and bone morphognetic protein 2 (BMP2) were evaluated along with the changes in body weight, water intake and glycemic profile. Real-Time RT-PCR and Western Blotting were used to evaluate gene and the protein expression. Data were submitted to statistical analysis using two-way ANOVA followed by Tukey test $(\alpha=0,05)$. Results: On group D+RME it was observed an increased bone resorption, serveral undermining and tissue degradation areas. On the suture gap there were mainly inflammatory and osteoclasts cells associated with compromised bone formation compared to groups $\mathrm{D}$ and $\mathrm{Cd}$. These results were observed also in molecular levels, since there were a reduced osteogenesis and an upregulation of osteoclastogenesis, mainly in early period of healing. On group $\mathrm{D}$, bone formation was compromised compared to group $\mathrm{C}$, due to changes on genes and proteins expression which regulates bone metabolism, considering that there was more immature bone and incresead active remodeling areas until late periods. On group $\mathrm{Cd}$ it was observed bone remodeling, characterized by desorganized tissue on the gap of midpalatal suture, with intense inflammatory hemorhagic and resorptive areas compared to group $\mathrm{C}$. However until 10 days after RME, on group $D$ the gap was not completely filled with bone tissue. These results were observed on the signaling of molecular biomarkers on group $\mathrm{Cd}$, since they were changed compared to groups $\mathrm{C}$ and Dd. Conclusions: DM modify the signaling for bone metabolism and compromise bone repair after RME. During orthopedic and orthodontic treatment is necessary to evaluate metabolism status of subjects, since the application of these forces have been shown to promote undesirable effects mostly when associated with DM.
\end{abstract}

Key-words: streptozotocin, type 1 diabetes mellitus, rapid maxillary expansion, bone remodeling, bone repair. 


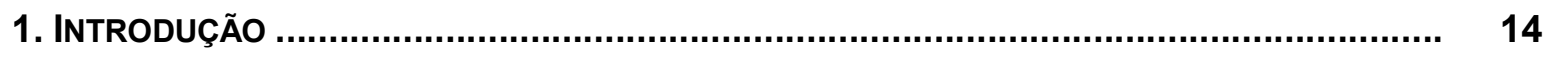

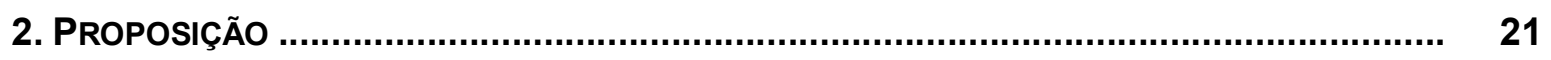

3. MATERIAL E MÉTODOS ............................................................................. 23

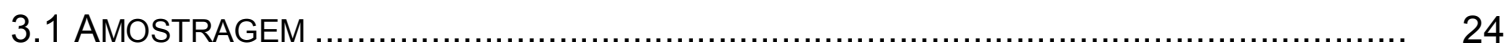

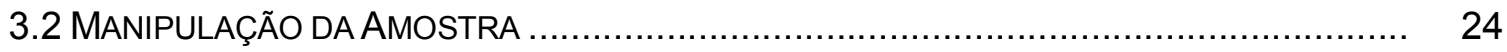

3.3 ANESTESIA DOS ANIMAIS............................................................................ 26

3.4 MENSURAÇÃO DA GLICEMIA, INDUÇÃO E AVALIAÇÃO DO DIABETES MELLITUS ............ 27

3.5 PROCEDIMENTO DE ERM OU DISJUNÇÃO MAXILAR.............................................. 27

3.6 INSTALAÇÃO DO DISPOSITIVO ORTODÔNTICO PARA DISJUNÇÃO MAXILAR ................. 28

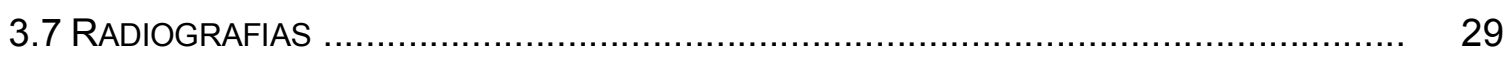

3.8 AVALIAÇÕES CLÍNICAS............................................................................ $\quad 30$

3.9 EUTANÁSIA DOS ANIMAIS E REMOÇÃO DOS ESPÉCIMES ……................................. 31

3.10 PROCESSAMENTO HISTOLÓGICO ……...................................................... 31

3.11 AVALIAÇÃO HISTOLÓGICA ......................................................................... 33

3.12 ANÁLISE DA EXPRESSÃO GÊNICA ATRAVÉS DA REAÇÃO DA POLIMERASE EM CADEIA EM TEMPO REAL (qRT-PCR) ………………………................................. 33

3.13 ANÁLISE PROTEICA ATRAVÉS DA TÉCNICA DE WESTERN BLOTTING ......................... 38

3.14 ANÁLISE ESTATISTICA ......................................................................... 42

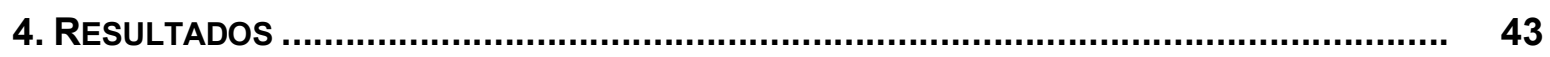

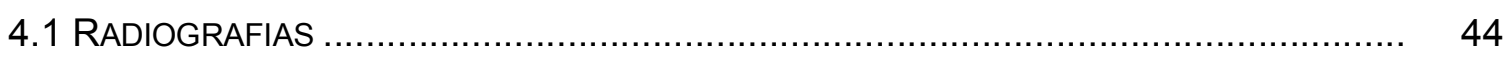

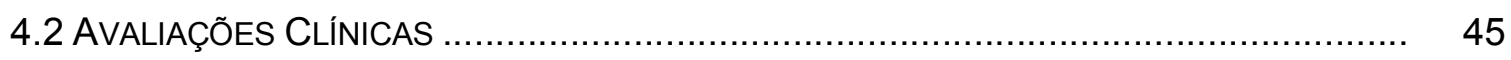

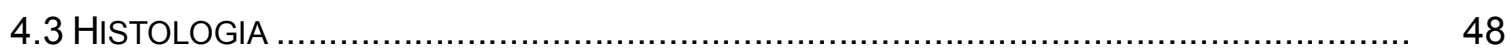

4.4 qRT-PCR E WESTERN BLOTTING ............................................................ 68

4.5 Bandas PROTEICAS IMUNORREATIVAS ObTIDAS PELA TÉCNICA DE Western

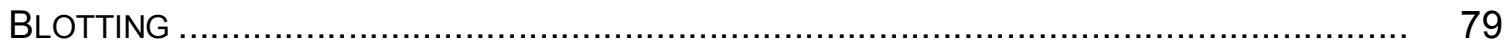

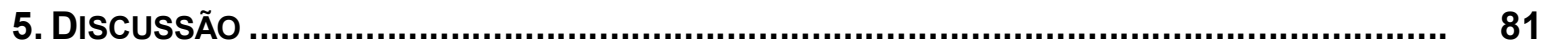

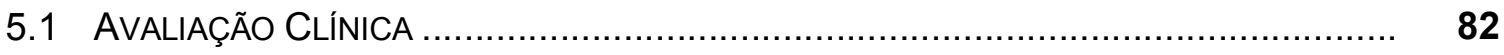

5.2 Avaliação Molecular (Expressão Gênica e Proteica) e análise 84 HISTOLÓGICA.

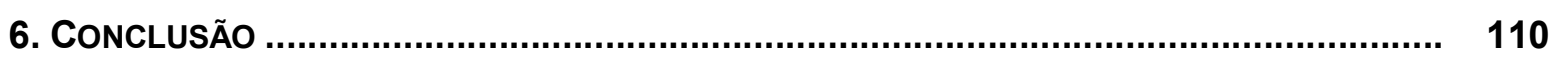

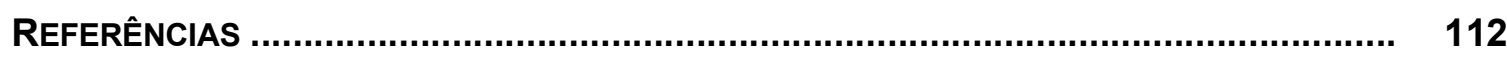

ANEXO 


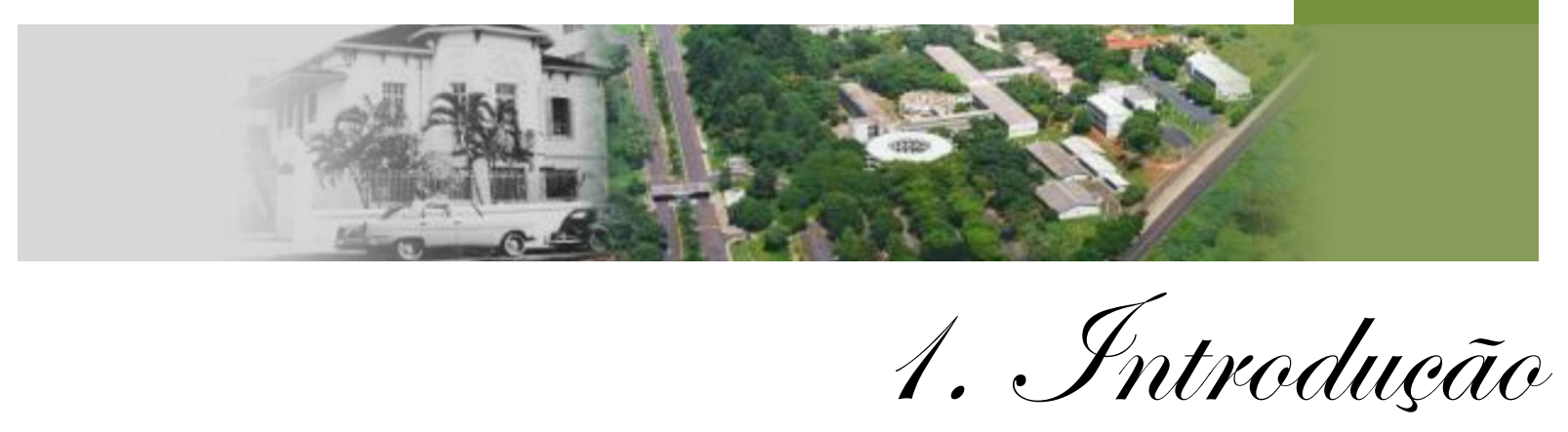




\section{INTRODUÇÃO}

Há diversas alterações sistêmicas que afetam os indivíduos que procuram tratamento odontológico. Uma doença de extrema importância e prevalente, que afeta crianças, adolescentes e adultos é o diabetes mellitus (DM). A população mundial que apresenta o DM aumentou de 153 milhões em 1980 para 347 milhões em 2008. Este crescimento vertiginoso é devido ao aumento e envelhecimento populacional, seguido da prevalência específica relacionada a cada faixa etária, assim como ao tipo de dieta, estilo de vida, sedentarismo, obesidade e acesso ao tratamento médico (SBD, 2009; Danaei et al., 2011). Na realidade há uma verdadeira pandemia de diabetes e a estimativa é de 472 milhões de diabéticos no mundo em 2030 (Danaei et al., 2011).

A maior prevalência de DM e a maior média de glicose em jejum no plasma sanguíneo foram obtidas na região da Oceania, seguida pelo Sul da Ásia, América Latina e Caribe, Ásia Central, Norte da África e Meio Oeste Europeu. Quarenta porcento das pessoas com DM concentram-se na China e na Índia, 12\% no Brasil, Paquistão, Indonésia, Japão e México e $10 \%$ nos EUA e Rússia. Atualmente já se sabe que um em cada quatro adultos norte-americanos apresentam DM (Danaei et al., 2011). Em 2010 havia aproximadamente 7,6 milhões de brasileiros diabéticos entre 20 e 79 anos de idade. (Shaw et al., 2010). Contudo, segundo informações da Sociedade Brasileira de Diabetes, este número já ultrapassou 12 milhões de pessoas com DM. O Brasil provavelmente será um dos principais países em desenvolvimento com mais pessoas afetadas pelo DM no mundo, podendo estar entre os cinco países mais afetados pela doença em 2030 (Amos, 1997; Wild et al., 2004; Shaw et al., 2010).

O DM é uma doença crônica caracterizada por um grupo heterogêneo de desordens metabólicas, essencialmente definida pelo aumento da concentração plasmática de glicose no sangue. A hiperglicemia se desenvolve tanto pela deficiência da produção de insulina no pâncreas quanto pela redução da ação da insulina (SBD, 2009; ADA, 2011). Esta doença leva o paciente ao risco de complicações crônicas de caráter micro e macrovascular. As microangiopatias estão associadas com complicações clínicas clássicas como retinopatia, nefropatia e neuropatia. Ao passo, que macroangiopatias são complicações relacionadas com doença isquêmica do coração, infarto e doenças vasculares periféricas (WHO 1999; WHO, 2006). O DM também tem sido responsável por alterar e comprometer o processo de reparo ósseo e de tecido mole (Mishima et al., 2002; Lu et al., 2003; Thrailkill et al., 2005; Villarino et al., 2011, Shibuya et al., 2013), aumentar a suscetibilidade à doença periodontal (IDF, 2009; Um et al., 2010) e à infecção oral (Lima et al., 2013). 
Além disso, há evidências de que pacientes diabéticos apresentam anormalidades de desenvolvimento da maxila e mandíbula. Estudos clínicos e experimentais (El-Bialy, AboulAzm, El-Sakhawy, 2000; Giglio, Lama, 2001; Abassy, Watari, Soma, 2010) relataram uma diminuição nos parâmetros cefalométricos e atraso no desenvolvimento esquelético em pacientes com DM1, fatores que predispõe às maloclusões. Assim, nos indivíduos acometidos pelo DM, essas diversas alterações geram uma redução da qualidade e expectativa de vida e significante morbidade (WHO 1999; Hogan et al., 2003; WHO, 2006; SBD, 2009).

O DM é classificado baseado na sua etiologia. De acordo com a Organização Mundial da Saúde (OMS) e Associação Americana de Diabetes (ADA) há quatro classes clínicas de diabetes, DM tipo 1 (DM1), DM tipo 2 (DM2), DM gestacional e outras formas específicas de diabetes devido a outras causas, tais como DM de origem genética, medicamentosa ou infecciosa. Além disso, há duas categorias, que não são consideradas entidades clínicas, mas são fatores de risco ao DM e à doenças cardiovasculares (DCVs), sendo assim referidas como estágios pré-diabéticos, que são a glicemia de jejum alterada e a tolerância à glicose diminuída (WHO, 1999; ADA, 2011).

O DM1 é caracterizado pela destruição parcial ou completa das células beta $(\beta)$ do pâncreas, o que gera a deficiência de insulina. Esta categoria pode ser de origem autoimune ou idiopática. Por outro lado o DM2 caracteriza-se por defeitos na ação e secreção de insulina associado ao quadro de sobrepeso ou obesidade do paciente. O DM gestacional é qualquer intolerância à glicose diagnosticada durante a gravidez, devido às mudanças hormonais. Os quadros clínicos de pré-diabetes são caracterizados por um estágio intermediário entre homeostase de glicose e DM (SBD, 2009; WHO, 1999; ADA, 2011; ADA, 2014).

Atualmente aceitam-se três critérios para o diagnóstico de DM. O primeiro critério trata-se das condições de poliúria, polifagia, polidipsia e perda de peso associados à glicemia sanguínea casual acima de 200 miligramas $(\mathrm{mg})$ de glicose por decilitro (dl) de sangue. $O$ segundo critério está relacionado à glicemia plasmática de jejum (GPJ) (oito horas sem ingestão de alimentos) que deve ser igual ou superior ao valor de $126 \mathrm{mg} / \mathrm{dl}$. O terceiro critério é baseado no teste oral de tolerância à glicose (TOTG), isto é, a avaliação glicêmica de duas horas pós-sobrecarga de $75 \mathrm{~g}$ de glicose com valores acima de 200 mg/dl (SBD, 2009). Entretanto, mais recentemente foi recomendado o uso do teste $\mathrm{A} 1 \mathrm{C}$ para o diagnóstico de diabetes. O A1C é um teste de hemoglobina glicada (HbA1c) com limiar abaixo ou igual a $6,5 \%$. Este exame resume o valor glicêmico do paciente no período anterior de 60 a 90 dias, uma vez que é neste período que a hemoglobina incorpora glicose, de acordo com a concentração deste açúcar no sangue (ADA, 2011; ADA, 2014).

Em resposta ao aumento do número de pacientes e do interesse em torno do diabetes, a Federação Internacional de Diabetes (FID) vinculada a OMS criou em 1991 o dia mundial de controle e prevenção do diabetes, celebrado no dia 14 de novembro. No Brasil o 
dia nacional do DM é comemorado no dia 27 de junho e há uma Lei Federal n 11.347/2006 que está em vigor desde 2007, que determina que pacientes diabéticos devem receber gratuitamente pelo Sistema Único de Saúde (SUS), os medicamentos necessários para o tratamento, assim como os materiais exigidos para a sua aplicação e a monitoração da glicemia capilar (glicosímetro). Desta forma, observa-se que esta doença é um grande problema de saúde pública e deve ser encarada como uma doença de crescente interesse em pesquisas na área médico-odontológica, principalmente no campo da ortodontia, ortopedia facial periodontia e cirurgia.

A expansão rápida da maxila (ERM) ou disjunção maxilar é um procedimento ortopédico que visa tratar a mordida cruzada posterior dental, esquelética ou associação de ambas, além de ser indicada para corrigir diversas discrepâncias antero-posteriores associadas ou não a mordida cruzada posterior. A mordida cruzada posterior é uma maloclusão transversal, que se manifesta como uma constrição uni ou bilateral do arco dentário e muitas vezes está associada ao apinhamento dental (Haas, 1961; 1965; 1980). Esta maloclusão deve ser tratada tão logo seja diagnosticada, visto que interfere no crescimento e desenvolvimento das estruturas crânio-maxilo-faciais, isto é, a correção desta maloclusão modifica o padrão de crescimento, expande de maneira geral os ossos do terço médio da face (Iseri et al., 1998; Ong et al., 2013; Zandi et al., 2014) e devolve um padrão facial mais harmônico.

Quando o procedimento de ERM é empregado para correção da mordida cruzada posterior, observa-se o afastamento dos ossos palatinos em direção lateral, a abertura da sutura palatina mediana e o aparecimento de um diastema entre os incisivos centrais superiores. Além disso, observa-se a redução da profundidade do palato, a maxila e a mandíbula geralmente se deslocam para frente e para baixo, os dentes mandibulares acompanham os dentes maxilares, há aumento da largura nasal, principalmente na região do assoalho nasal, a maioria dos ossos que se articulam com a maxila são deslocados, ocorrem mudanças nos tecidos moles e também ocorre um balanço mais favorável das forças musculares envolvidas (Haas, 1961; Bishara, Orhto, Staley, 1987; Iseri et al., 1998; Cross e McDonald, 2000; Ong et a.l, 2013; El e Palomo, 2014). Após um período de pelo menos 3 a 6 meses de estabilização e contenção do aparelho ortodôntico, é possível notar a deposição e a formação de tecido ósseo mineralizado na região da sutura, desaparecimento do diastema entre os incisivos e a correção da maloclusão transversa (Haas, 1961; 1965; 1980; Takenouchi et al., 2014).

Desta maneira, observa-se que a mordida cruzada posterior é uma maloclusão de grande interesse científico, uma vez que necessita de intervenção ortodôntica precoce, a fim de evitar alterações permanentes nas estruturas maxilo-faciais. Entretanto, não há estudos in vivo que relacionem a ERM com doenças sistêmicas prevalentes como o DM. Além disso, 
pouco se sabe sobre as possíveis interferências, implicações e os diversos efeitos do DM no processo de remodelação óssea durante aplicação de forças ortopédicas utilizadas para direcionar o crescimento e desenvolvimento crânio-facial (Villarino et al., 2011).

Os eventos celulares e moleculares que ocorrem durante a osteogênese tem sido amplamente investigados com a finalidade de compreender o processo de remodelação óssea. Em Ortodontia, a aplicação de forças mecânicas de grande magnitude, são utilizadas com a finalidade de modificar a forma dos ossos craniofaciais e alterar o crescimento e desenvolvimento ósseo. Os aparelhos craniofaciais ortopédicos distribuem forças intensas e em macro-escala, produzindo assim uma tração microestrutural e induzindo resposta de proliferação e diferenciação celular nas suturas ósseas (Rygh e Moyers, 1991; Roberts-Harry e Sandy, 2004; Krishnan e Davidovitch, 2006).

A remodelação óssea é orquestrada por células da linhagem osteoblástica e envolve uma rede complexa de interações célula-célula, célula-matriz e de múltiplas vias de sinalização celular, juntamente com a participação de hormônios sistêmicos, fatores de crescimento, produção de citocinas locais, que atuam de maneira autócrina e parácrina (Meikle, 2006). Estas moléculas podem estimular muitas respostas celulares através de diversos tipos de células no tecido ósseo, desta forma, fornecendo um microambiente favorável para deposição ou reabsorção tecidual (Davidovitch et al.,1988; Davidovitch,1991).

Descobertas recentes na área de remodelação óssea, mais especificamente no campo dos biomarcadores de turnover ósseo, tem tornado as pesquisas sobre tratamento ortodôntico, ortopédico, cirúrgico e desordens metabólicas como o DM, mais direcionadas e focadas principalmente na análise de genes e das proteínas envolvidas durante estes processos. Tais marcadores por serem derivados do osso cortical e trabecular, refletem a atividade metabólica do tecido ósseo (Cox et al., 2010), além de fornecer uma visão dinâmica do processo de formação e reabsorção óssea funcionando como indicadores da função dos osteoblastos e dos osteoclastos e, portanto, do processo de remodelação óssea (Camozzi et al., 2007).

Na literatura há diversos estudos que relacionam DM e remodelação óssea utilizando diferentes protocolos (Mishima et al, 2002, Lu et al., 2003; Holzhausen et al., 2004; Thraikill et al., 2005; Alexopoulou et al., 2006; Botolin e McCabe, 2006; Fowkles et al., 2008, Motyl et al., 2009; Dayem et al., 2011; Chang et al., 2012; Silva et al., 2012; Antonoglou et al., 2013; Coe, Zhang, McCabe, 2013; Cintra et al., 2013; Xu et al., 2013; Soboku et al., 2014). Nestas avaliações foi possível concluir que o DM interferiu de maneira negativa no processo de remodelação óssea, ao passo que a reversão deste quadro foi alcançada quando da utilização de insulinoterapia.

Diante destes conhecimentos alguns autores investigaram o impacto desta doença no tratamento ortodôntico. Neste contexto, os estudos foram mais direcionados para 
avaliações histológica e histomorfométrica (Li et al., 2010; Braga et al., 2011; Zhang, Li, Bi, 2011; Villarino et al., 2011; Maia et al., 2014). Contudo, ainda é muito escasso as pesquisas que estudam DM associado às forças ortodônticas utilizando metodologias direcionadas principalmente à avaliações gênicas e proteicas (Li et al., 2010; Zhang, Li, Bi, 2011; Braga et al., 2011). Tais pesquisas observaram que o DM associado ao estresse ortodôntico também alterou a remodelação óssea, sugerindo que o curso deste tratamento poderia ser mais prolongado em pacientes diabéticos do que em pacientes normoglicêmicos (Li et al., 2010). Além disso, sugeriram que pacientes com DM não monitorados não deveriam receber tratamento ortopédico, mesmo quando necessário, até restabelecerem o estado de normoglicemia, uma vez que a aplicação destas forças poderiam causar efeitos indesejáveis (Villarino et al., 2011).

Apesar dos estudos sobre DM e ortodontia mostrarem que em pacientes e animais diabéticos há um processo de reparo ósseo comprometido quando do emprego de estresse ortodôntico, é importante reforçar que ainda não há estudos que mostram as alterações no processo de formação óssea no longo prazo da doença instalada durante à aplicação de forças de grande magnitude, como ERM ou disjunção maxilar. Além disso, também não há pesquisas direcionadas a fim de esclarecer neste contexto o processo de remodelação óssea utilizando técnicas de avaliações gênicas e proteicas.

Desta maneira, um melhor entendimento das mudanças dos marcadores do turnover ósseo durante a aplicação de forças ortopédicas quando da presença de diabetes mellitus tipo 1 é de grande interesse, uma vez que esta análise pode potencialmente levar ao conhecimento das razões pelas quais a formação óssea é reduzida (Mishima et al., 2002, Lu et al., 2003; Thraikill et al., 2005; Fowkles et al., 2008), atrasada e comprometida nesta doença (Li et al., 2010; Zhang, Li, Bi, 2011; Braga et al., 2011; Villarino et al., 2011; Maia et al., 2014). Além do mais, poderá levar ao entendimento das razões pelas quais o tratamento ortodôntico poderia ser mais prolongado em pacientes diabéticos (Li et al., 2010).

Portanto, diante de diversos trabalhos da literatura que mostram a viabilidade e as importantes descobertas do estudo relacionado ao diabetes mellitus e a osteogênese, é de grande relevância associar e somar estes conhecimentos ao tratamento ortodôntico utilizando aparelhos para expansão maxilar rápida da sutura palatina mediana e a biologia molecular, visto que esta nova abordagem de estudo e avaliação é inicialmente inovadora.

Desta maneira, é importante avaliar neste contexto a expressão gênica e proteica da tríade RANK (Receptor Ativador do Fator Nuclear kappa B), RANKL (ligante para RANK) e osteoprotegerina (OPG), que são fatores envolvidos na sinalização osteoblasto-osteoclasto, assim como, avaliar as proteínas não-colagenas como a osteonectina (ONC), osteocalcina (OCC), sialoproteína óssea (BSP), osteopontina (OPN) e proteína morfogenética óssea 2 (BMP2), que são indicadores de atividade celular, cuja secreção é realizada pelos 
osteoblastos e que estão envolvidas no processo de formação óssea.

Visto que o diabetes mellitus é um problema de saúde pública de grande relevância no mundo, principalmente no Brasil, que essa doença sistêmica interfere no processo de remodelação óssea durante a movimentação dentária ortodôntica e considerando a importância da detecção dos diferentes mediadores bioquímicos que atuam e interferem neste processo, acredita-se ser de fundamental interesse avaliar, pela primeira vez, diferentes mediadores que estão envolvidos e modulam o processo de remodelação óssea durante a ERM em ratos diabéticos-induzidos em avaliações de DM de longo prazo, haja vista que a mordida cruzada é uma maloclusão que merece destaque, uma vez que interfere no desenvolvimento crânio-facial. 


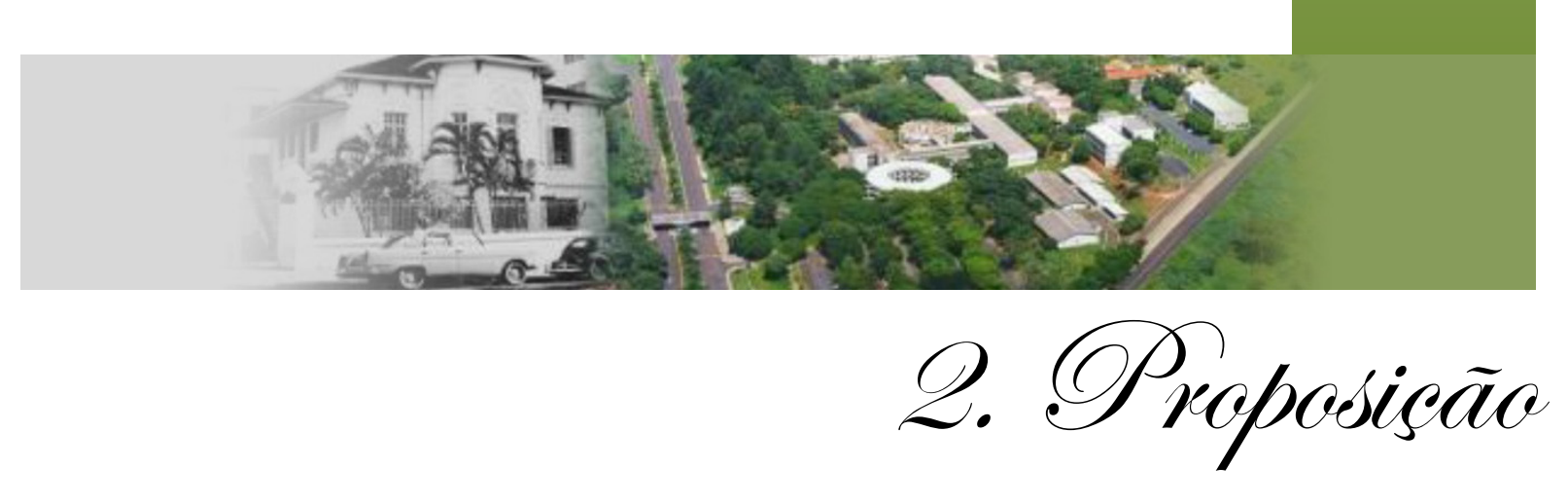




\section{PROPOSIÇÃo}

O objetivo do presente estudo foi investigar os mediadores que modulam o processo de remodelação óssea em ratos com diabetes mellitus tipo 1 submetidos ou não à forças ortopédicas para expansão rápida da maxila.

\subsection{Objetivos específicos}

1. Avaliar a influência do diabetes mellitus tipo 1 na remodelação óssea após a expansão rápida da maxila por meio da avaliação da expressão gênica e proteica de RANK (Receptor Ativador do Fator Nuclear kappa B), RANKL (ligante para RANK), osteoprotegerina (OPG), osteonectina (ONC), osteocalcina (OCC), osteopontina (OPN), sialoproteína óssea (BSP) e proteína óssea morfogenética 2 (BMP2), em diferentes períodos de avaliação.

2. Verificar se há diferença quantitativa destes mediadores que modulam remodelação óssea em animais diabéticos submetidos ou não à ERM e em animais sadios, em diferentes períodos de avaliação.

3. Avaliar qualitativamente, através de descrições histológicas, a remodelação óssea na sutura palatina mediana após a expansão rápida da maxila nos diferentes tempos e grupos de análise. 


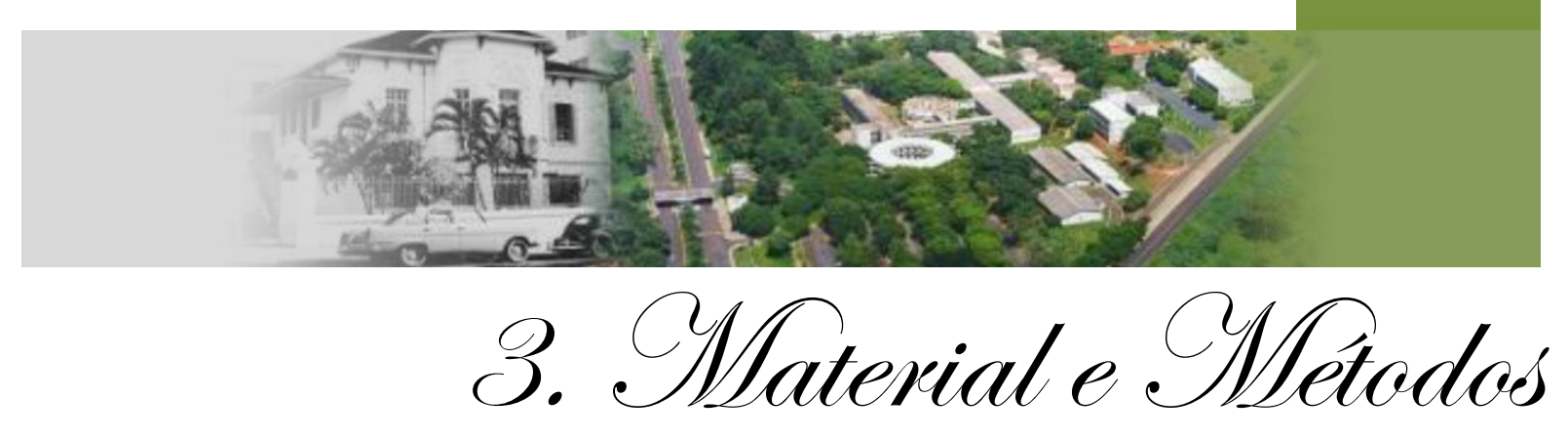




\section{MATERIAL e MÉtodos}

\subsection{Amostragem (Seleção dos Animais)}

Este experimento utilizou um total de 150 ratos da linhagem Wistar (Rattus norvegicus albinus), machos, com 60 dias de vida (adultos), pesando em média 350-400g. Os ratos foram fornecidos pelo Biotério Central da Universidade de São Paulo, câmpus de Ribeirão Preto. Este projeto teve a aprovação da Comissão de Ética no Uso de Animais (CEUA - USP), sob protocolo 10.1.1026.53.6 (Anexo). Durante o período experimental os animais tiveram livre acesso à água e foram alimentados com dieta padrão. A ração convencional em grãos (Labina - Purina) foi fornecida aos ratos sem instalação de aparelho ortodôntico e a ração convencional moída (Labina - Purina) foi fornecida aos ratos submetidos a expansão rápida da maxila, a fim de se evitar eventuais danos ao aparelho ortodôntico durante a mastigação.

\subsection{Manipulação da Amostra}

Os animais foram distribuídos em 8 grupos de estudos. Grupos controles: Controle (C), Veículo (V), Diabético (D) e grupos experimentais: Controle + disjunção maxilar (Cd), Veículo + disjunção maxilar (Vd) e Diabético + disjunção maxilar (Dd). Cada subgrupo de estudo foi dividido em três tempos de estudos: 3 dias, 7 dias e 10 dias de avaliação. Os grupos C, D, Cd e Dd foram constituídos de 10 animais $(n=10)$ por cada tempo, sendo que cinco animais foram destinados às avaliações da expressão gênica e proteica e 5 animais destinados às avaliações histológicas e histométricas. Os grupos $\mathrm{V}$ e Vd foram constituídos de 5 animais $(n=15)$ para cada tempo de avaliação, uma vez que inicialmente pretendia-se avaliar se estes animais teriam o mesmo comportamento clínico e histológico que seria encontrado nos animais do grupo controle. Abaixo está a descrição detalhada de cada grupo de animais.

a) Controle (C) - constituído de dez animais saudáveis para cada tempo experimental. No primeiro dia de experimento foram avaliados os valores de normoglicemia, de jejum utilizando

glicosímetro One Touch Ultra 2 (Johnson \& Johnson Medical S.A., Shangai, China). No 
segundo dia, estes valores foram reavalidados e no vigésimo oitavo dia a normoglicemia foi confirmada. Estes ratos não foram submetidos a qualquer procedimento clínico. A eutanásia foi realizada nos períodos de 3, 7 e 10 dias após decorridos 28 dias iniciais de experimento.

b) Controle + disjunção maxilar (Cd) - constituído de dez animais saudáveis para cada tempo experimental. No primeiro dia de experimento foram avaliados os valores de normoglicemia de jejum utilizando glicosímetro. No segundo dia, estes valores foram reavalidados e no vigésimo oitavo dia a normoglicemia foi confirmada. Estes ratos foram submetidos à disjunção maxilar após 28 dias do início do experimento e a eutanásia foi realizada nos períodos de 3, 7 e 10 dias após o procedimento ortodôntico.

c) Veículo (V) - constituído de cinco animais para cada tempo experimental. No primeiro dia de experimento, foram avaliados os valores normoglicêmicos em jejum e nestes animais foi injetado o veículo tampão citrato (Sigma-Aldrich Chemical, St. Louis, MO, EUA) a 0,09 M e $\mathrm{pH}=4,5$. No segundo dia, estes valores foram reavalidados e no vigésimo oitavo dia a normoglicemia foi confirmada. Estes ratos não foram submetidos a qualquer procedimento clínico. A eutanásia destes animais foi realizada nos períodos de 3, 7 e 10 dias após decorridos 28 dias de experimento.

d) Veículo + disjunção maxilar (Vd) - constituído de cinco animais para cada tempo experimental. Estes animais foram expostos aos mesmos cuidados e tratamentos realizados no grupo $\mathrm{V}$. Aos 28 dias de experimento estes animais foram submetidos à expansão rápida da maxila. A eutanásia foi realizada nos períodos de 3,7 e 10 dias após o procedimento ortodôntico.

e) Diabético (D) - constituído de dez animais para cada tempo experimental. No primeiro dia de experimento, foram avaliados os valores de normoglicêmia em jejum e posteriormente estes animais foram induzidos ao diabetes mellitus. Para este procedimento utilizou-se o medicamento estreptozotocina (STZ) (Sigma-Aldrich Chemical, St. Louis, MO, EUA) na concentração de $50 \mathrm{mg} / \mathrm{kg}$ por peso e diluído em veículo tampão citrato, por via intraperitoneal. Os valores de hiperglicemia foram validados no segundo dia de experimento. No vigésimo oitavo dia foi reavaliado e confirmado os valores hiperglicêmicos. A eutanásia destes animais foi realizada nos períodos de 3, 7 e 10 dias após 28 dias de experimento.

f) Diabético + disjunção maxilar (Dd) - constituído de dez animais para cada tempo experimental. Estes animais foram expostos aos mesmos cuidados e tratamentos realizados no grupo D. Aos 28 dias após a reavaliação da hiperglicemia estes animais foram submetidos 
à expansão rápida da maxila. A eutanásia foi realizada nos períodos de 3,7 e 10 dias após o procedimento ortodôntico.

No Quadro 1 está resumido a distribuição dos animais nos diferentes grupos e períodos de estudo.

Quadro 1: Distribuição dos animais nos diferentes grupos de estudo e subdivididos nos três tempos experimentais.

\begin{tabular}{|c|c|c|c|c|c|c|c|}
\hline \multirow{3}{*}{ GRUPOS } & \multicolumn{6}{|c|}{ TEMPO EXPERIMENTAL } & \multirow{3}{*}{ DESCRIÇÃO DOS GRUPOS } \\
\hline & \multicolumn{2}{|c|}{3 dias } & \multicolumn{2}{|c|}{7 dias } & \multicolumn{2}{|c|}{10 dias } & \\
\hline & $\begin{array}{c}\text { RNA E } \\
\text { PROTEÍNA }^{1}\end{array}$ & HIST $^{2}$ & $\begin{array}{c}\text { RNA E } \\
\text { PROTEÍNA }^{1}\end{array}$ & HIST $^{2}$ & \begin{tabular}{c|} 
RNA E \\
PROTEÍNA $^{1}$
\end{tabular} & HIST $^{2}$ & \\
\hline C & 5 ratos & 5 ratos & 5 ratos & 5 ratos & 5 ratos & 5 ratos & 30 animais no grupo Controle \\
\hline Cd & 5 ratos & 5 ratos & 5 ratos & 5 ratos & 5 ratos & 5 ratos & 30 animais no grupo Controle + disjunção maxilar \\
\hline $\mathbf{v}$ & - & 5 ratos & - & 5 ratos & - & 5 ratos & 15 animais no grupo veículo \\
\hline Vd & - & 5 ratos & - & 5 ratos & - & 5 ratos & 15 animais no grupo Veículo + disjunção maxilar \\
\hline D & 5 ratos & 5 ratos & 5 ratos & 5 ratos & 5 ratos & 5 ratos & 30 animais no grupo Induzidos ao diabetes \\
\hline Dd & 5 ratos & 5 ratos & 5 ratos & 5 ratos & 5 ratos & 5 ratos & 30 animais no grupo Induzidos ao diabetes + disjunção maxilar \\
\hline TOTAL & & & 150 anir & & & & Total de animais distribuídos nos diferentes grupos experimentais \\
\hline
\end{tabular}

${ }^{1}$ RNA E PROTEÍNA - Avaliação da expressão gênica e de proteínas; ${ }^{2}$ HIST - Avaliação histológica

\subsection{Anestesia dos Animais}

Todos os procedimentos foram realizados sob sedação com Ketamina a $10 \%$ (anestésico) (Ketamina Agener, Agener União, SP, Brasil) e Xylazina a 2\% (relaxante muscular) (Dopaser, Calier, Espanha) numa proporção 1:2, respectivamente, por via intramuscular, exceto o procedimento de mensuração dos valores glicêmicos que não foi realizado sob sedação e anestesia, uma vez que os medicamentos empregados nesta técnica alteravam os valores glicêmicos dos animais. A avaliação da glicose capilar utilizando glicosímetro com fita reagente na cauda do rato foi realizada com o animal acordado e com auxílio de contenção manual. 


\subsection{Mensuração da glicemia, Indução e Avaliação do Diabetes Mellitus}

Os animais dos grupos D e Dd foram induzidos ao diabetes mellitus, através da administração de dose única da droga STZ no primeiro dia do experimento (dia zero). Utilizouse a concentração de $50 \mathrm{mg} / \mathrm{kg}$ por peso de STZ, diluída em veículo tampão citrato (Sigma Chemical, St. Louis, MO) a 0,09 M e pH = 4,5, por via intraperitoneal (Nascimento-Saba, Breitenbach, Rosenthal, 1997; Ortiga-Carvalho, Curty, Nascimento-Saba et al., 1997; Li et al 2010; Villarino, Lewicki, Ubios, 2011), com seringa de $1 \mathrm{ml}$ (BD Ultra-Fine ${ }^{\mathrm{TM}}$, SP, Brasil) e agulha acoplada de 12,7 mm (BD Ultra-Fine ${ }^{\mathrm{TM}}$ Original, SP, Brasil).

No primeiro dia de experimento após 10 horas de jejum diurno, previamente a indução do diabetes, foi mensurada a glicemia de todos os animais. Após quarenta e oito horas da indução, todos os animais da amostra foram novamente submetidos ao exame sanguíneo para verificação da concentração de glicose capilar.

A verificação da hiperglicemia foi feita na cauda do rato. A veia caudal do rato foi dilatada com o auxílio de água à temperatura de $30^{\circ} \mathrm{C}$. No terço médio e inferior da cauda do rato foi feita uma punção venosa, a fim de coletar o sangue para verificação da glicemia. $O$ sangue foi gotejado em fita reagente específica para o aparelho One Touch Ultra (Johnson \& Johnson Medical S.A., China), que realizou imediatamente a leitura da glicemia. A concentração de glicose padronizada foi menor que $126 \mathrm{mg} / \mathrm{dl}$ para os animais dos grupos $\mathrm{C}$, $\mathrm{Cd}, \mathrm{V}$ e Vd e maior que $300 \mathrm{mg} / \mathrm{dl}$ para os grupos STZ-injetados. Exames semelhantes foram realizados no vigésimo oitavo dia de experimento, a fim de confirmar os ratos normoglicêmicos e hiperglicêmicos.

\subsection{Procedimento de ERM ou Disjunção Maxilar}

No vigésimo oitavo dia de experimento os animais dos grupos $\mathrm{Cd}$, Vd e Dd foram submetidos ao procedimento de disjunção maxilar. Inicialmente os animais destes grupos foram anestesiados e posicionados em mesa operatória (Figura 1). O procedimento de disjunção maxilar foi realizado e uma mola ortodôntica passiva foi instalada entre os incisivos centrais para manutenção do procedimento de disjunção maxilar (Figura 2). Após a constatação clínica da disjunção foi instalado o aparelho ortodôntico (Figura 3). 


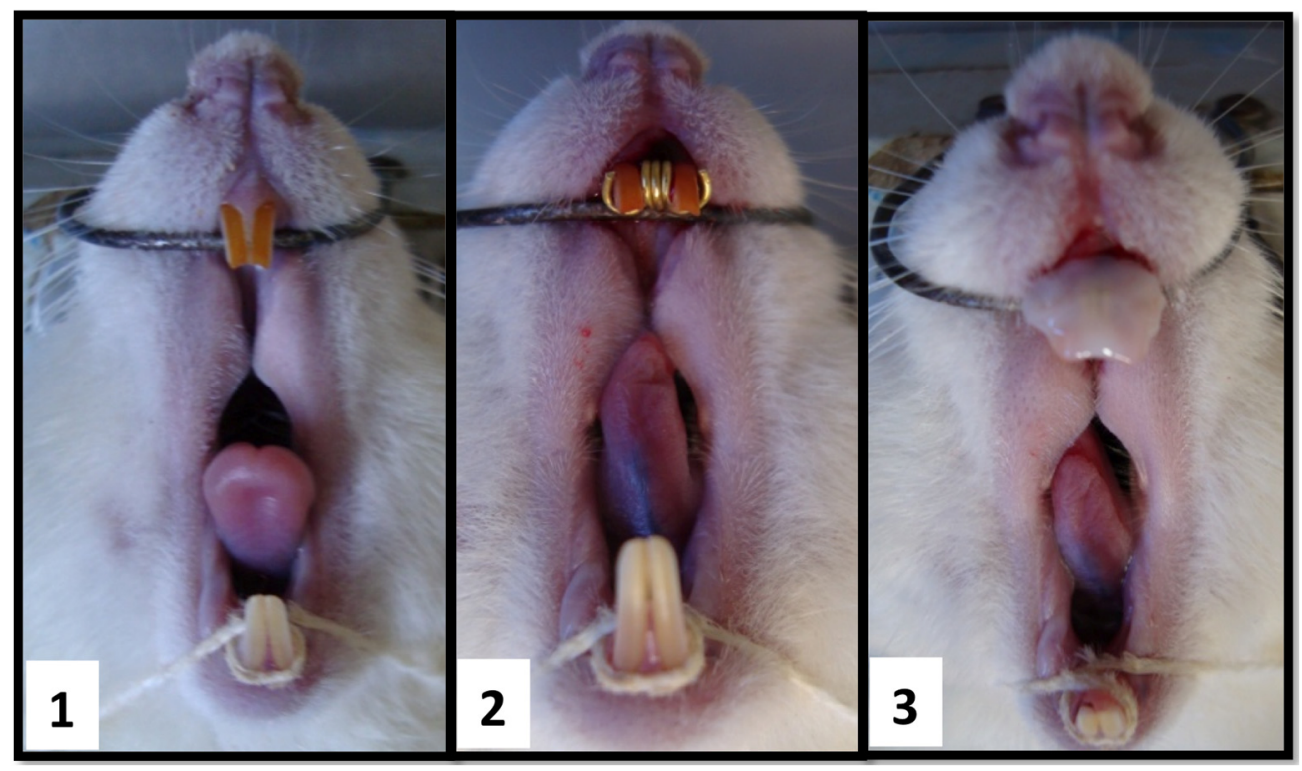

Figura 1: Rato em posição operatória para realizar procedimento de disjunção maxilar.

Figura 2: Instalação da mola ortodôntica confeccionada com anel metálico circular (1,5 mm de largura $\times 0,5 \mathrm{~mm}$ de diâmetro).

Figura 3: Dispositivo ortodôntico fixado com ácido, adesivo e resina composta.

\subsection{Instalação do Dispositivo Ortodôntico para Disjunção Maxilar}

No vigésimo oitavo dia de experimento, nos animais dos grupos $\mathrm{Cd}, \mathrm{Vd}$ e $\mathrm{Dd}$ foi confeccionado um dispositivo ortodôntico para manter o procedimento de disjunção maxilar. O mecanismo de força utilizado foi constituído de uma mola passiva $(1,5 \mathrm{~mm}$ de largura de fio de aço inoxidável $\times$ 0,5 mm de diâmetro) (Morelli, SP, Brasil) posicionada entre os incisivos superiores semelhante ao apresentado na literatura por Sawada e Shimizu (1996) e Saito e Shimizu (1997) com o intuito de possibilitar a correta calibração e padronização da abertura da sutura palatina mediana.

$\mathrm{Na}$ montagem do dispositivo para disjunção foram utilizados alicate $\mathrm{n}^{\circ} 139$ (3M Unitek, SP, Brasil), alicate para corte de fio espesso (Dentaurum, Springen, Alemanha), espelho bucal (S.S. White, Duflex, RJ, Brasil), sonda exploradora $\mathrm{n}^{\circ} 5$ (S.S. White, Duflex, RJ, RJ, Brasil) e calcador de anéis (S.S. White, Duflex, RJ, Brasil). Todos os dispositivos ortodônticos foram confeccionados e instalados pelo mesmo operador e assistente, seguindo sempre o mesmo protocolo.

Previamente a inserção do aparelho entre os incisivos superiores, a superfície dos dentes foi preparada para aumentar a retenção e estabilizar o anel a ser confeccionado. Uma broca esférica diamantada n 1011 (K.G. Sorensen, SP, Brasil) montada em motor de alta rotação (Dabi-Atlante, SP, Brasil) foi utilizada para confeccionar sulcos rasos, no terço 
gengival das faces vestibular e distal dos incisivos superiores apenas em esmalte. Em seguida foi realizada profilaxia dos incisivos com pasta de pedra-pomes misturada com água aplicada em taça de borracha (Viking, SP, Brasil) em contra-ângulo adaptado ao micromotor (DabiAtlante, SP, Brasil) por 15 segundos. Realizou-se a lavagem com spray (água-ar) e a secagem com ar proveniente da seringa tríplice. O condicionamento ácido do esmalte nos incisivos foi realizado utilizando ácido ortofosfórico à $37 \%$ em forma de gel (3M, SP, Brasil), durante 60 segundos, conforme recomendações do fabricante. Na seqüência foi feita novamente a lavagem e secagem das superfícies dentárias, por 15 segundos, com o auxílio da seringa tríplice. O agente de união Primer \& Bond 2.0 (Dentsply, SP, Brasil) foi aplicado sobre a superfície condicionada do esmalte e fotopolimerizado com luz halógena por 20 segundos com auxílio do aparelho Heliomat II (Vigodent, RJ, Brasil).

A resina fotopolimerizável Transbond ${ }^{\mathrm{TM}}$ (3M Unitek, SP, Brasil) foi adaptada sobre o segmento de fio nas faces vestibular e distal recobrindo-o e, em seguida foi iniciada a polimerização por meio de luz halógena, com comprimento de onda de $470 \mathrm{~nm}$, durante 30 segundos, dirigida em orientação oclusal, vestibular, mesial e distal de cada incisivo. Para compensar o desgaste decorrente do hábito roedor contínuo dos animais, várias camadas de resina foram fotopolimerizadas sobre o aparelho. Após a ativação inicial, o aparelho não recebeu ativações adicionais durante o experimento e seu correto posicionamento foi conferido diariamente, quanto à posição, à estabilidade e à necessidade de correções na eventualidade de estar causando injúrias à mucosa oral do animal.

No esmalte dos dentes anteriores inferiores de todos os animais foi realizada um procedimento de ameloplastia, a fim de evitar a fratura do dispositivo instalado nos dentes superiores.

A espessura da mola de aço inoxidável foi determinada com base em resultados de um estudo preliminar (Sawada e Shimizu, 1996) que indicou que 1,5mm de expansão rápida da maxila entre os incisivos, induzia a taxa máxima de disjunção na sutura palatina mediana sem diminuição contínua do peso corpóreo do animal.

Todos os procedimentos operatórios foram realizados na sala de Cirurgia Experimental do Bioterio I da Faculdade de Odontologia de Ribeirão Preto da Universidade de São Paulo (FORP-USP), sob condições de assepsia e higiene adequadas e pelos mesmos operadores.

\subsection{Radiografias}

O exame radiográfico foi realizado no momento da eutanásia, a fim de confirmar a sutura intacta nos animais dos grupos que não foram submetidos à disjunção e confirmar a 
abertura da sutura palatina mediana após a disjunção. Estas radiografias foram realizadas neste período, uma vez que deste modo era possível a obtenção de radiografias comparáveis sem sobreposições ósseas.

Os animais foram radiografados utilizando filmes oclusais (Insight, Kodak, NY, EUA) que foram posicionados paralelos à sutura palatina mediana envolvendo toda a maxila. Utilizou-se o aparelho de Raio X (Kavo, Funk RX 10, RJ, Brasil) calibrado com tempo de exposição de 0,5 segundos, $10 \mathrm{~mA}$ e $60 \mathrm{KV}$ para obtenção de radiografias semelhantes. Os filmes radiográficos foram revelados em soluções de revelador (Kodak GBX, NY, EUA) e fixador (Kodak GBX, NY, EUA) de acordo com a técnica temperatura/ tempo com lavagem intermediária em água durante 30 segundos e fixação por 15 minutos. Posteriormente, as radiografias foram colocadas em água corrente por 20 minutos e a secagem foi obtida naturalmente.

\subsection{Avaliações Clínicas}

$\mathrm{Na}$ avaliação intra-bucal, foram observados o aspecto clínico gengival e os pontos de contato entre os incisivos centrais superiores de todos os animais previamente e após a disjunção e a instalação do aparelho ortodôntico.

A partir do terceiro dia de experimento iniciou-se a mensuração do consumo hídrico em mililitros ( $\mathrm{ml}$ ), a avaliação do peso em gramas $(\mathrm{g})$ e avaliações da glicemia sanguínea (mg/dl) em todos os animais da amostra. O consumo de água foi investigado a fim de se avaliar a polidipsia e o peso foi avaliado com o objetivo de observar quaisquer alterações relacionadas à alimentação e/ou às condições experimentais. A glicemia foi verificada para avaliar os animais normoglicêmicos e hiperglicêmicos. Tais procedimentos foram realizados diariamente na primeira semana de experimento e posteriormente semanalmente até o vigésimo oitavo dia. A partir do vigésimo oitavo dia de experimento confirmou-se os valores glicêmicos de cada grupo e as demais avaliações clínicas continuaram a ser realizadas diariamente até o dia da eutanásia.

Os procedimentos de pesagem e de avaliação do consumo hídrico foram realizados em balança digital (Filizola, SP, Brasil) e em garrafas de vidro graduadas, respectivamente. Todos os dados clínicos obtidos em relação ao peso, consumo de água e glicemia foram anotados em tabelas apropriadas.

Os procedimentos experimentais foram descritos no diagrama abaixo (Diagrama Experimental 1). 
Diagrama Experimental 1: Descrição dos procedimentos experimentais.

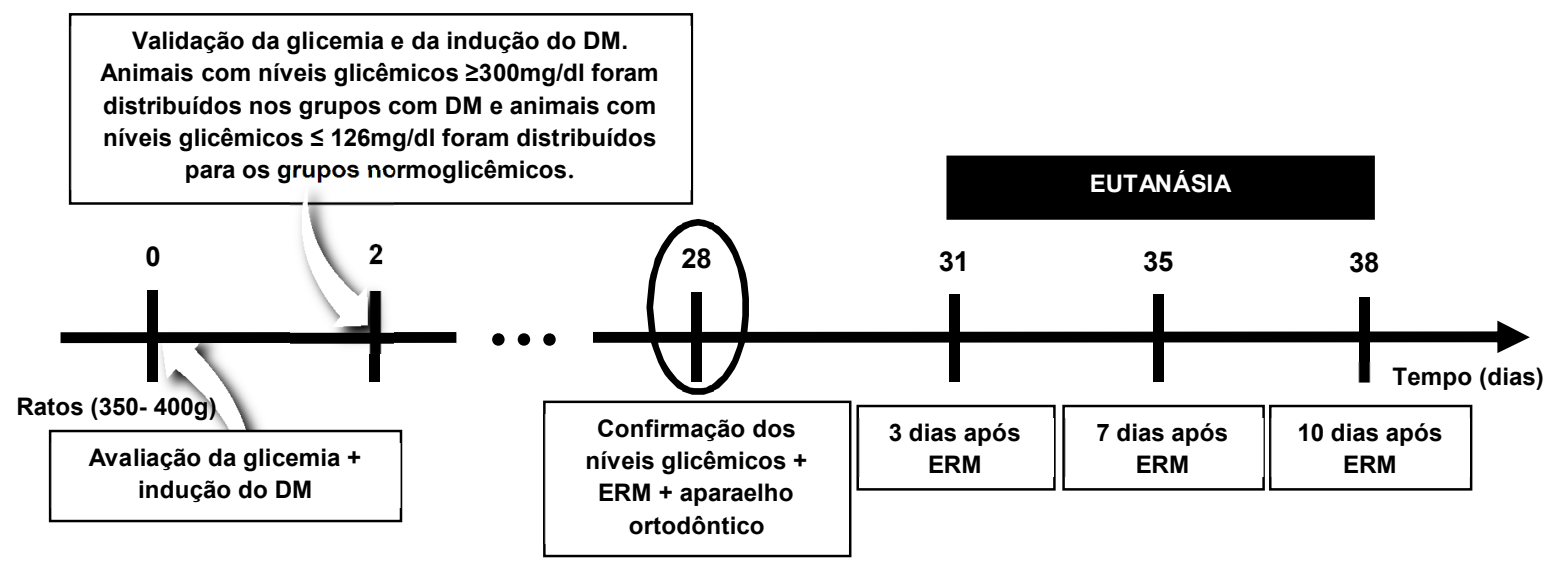

\subsection{Eutanásia dos Animais e Remoção dos espécimes}

A eutanásia dos animais foi realizada no terceiro, sétimo e décimo dias após decorrido 28 dias de período experimental, data em que foi realizado o procedimento de ERM em alguns grupos de estudo. Os animais foram anestesiados com Ketamina a 10\% $(75 \mathrm{mg} / \mathrm{Kg})$ e Xilazina a $2 \%(10 \mathrm{mg} / \mathrm{Kg})$ por via intramuscular, e em seguida mortos por decaptação em guilhotina. Espécimes contendo apenas o tecido da sutura palatina mediana dos diferentes grupos foram armazenados em tubos plásticos livres de RNAses (Eppendorf, São Paulo, Brasil), identificados e conservados em freezer a $-80^{\circ} \mathrm{C}$ para análise da expressão gênica e proteica. Espécimes contendo a maxila, incluindo a sutura palatina mediana, foram destinados à avaliação histológica e histométrica e foram conservados em formol a 10\% por 48 horas e posteriormente foi iniciado o processamento histológico.

\subsection{Processamento Histológico}

Após a eutanásia, as peças foram fixadas em formol tamponado a 10\% por 48 horas, em frascos individuais. Na sequência, os espécimes foram lavados em água corrente por 24 horas e colocados em solução desmineralizadora à base de EDTA a 10\% (etileno-diaminotetra-acético), tamponado em $\mathrm{pH}$ neutro $(7,0-7,4)$, por um período de 4 semanas. Durante a descalcificação, as peças foram armazenadas individualmente, em frascos esterilizados, 
contendo quantidade de solução descalcificadora equivalente a vinte vezes o volume da peça. Esta solução foi renovada a cada 72 horas, com o intuito de preservar a matriz orgânica durante o processo de descalcificação. A confirmação da descalcificação das secções anatômicas foi realizada através de radiografias obtidas das peças anatômicas, durante o período de descalcificação, a fim de avaliar o grau de calcificação das peças.

Depois de submetidos à desmineralização, todos os espécimes foram imersos em sulfato de sódio a $5 \%$ por 24 horas à temperatura ambiente, com a finalidade de neutralizar a ação da solução descalcificadora. Os espécimes foram lavados em água corrente por 24h. Posteriormente, foi realizada desidratação em concentrações crescentes de álcoois, $70 \%$, $80 \%, 90 \%$ e 100\% (Reagen, PR, Brasil), sucessivamente, por 60 minutos à temperatura ambiente, a fim de evitar trocas osmóticas bruscas, o que poderia causar alterações nas estruturas teciduais. Concluída a desidratação, as peças foram diafanizadas em três banhos de xilol (Merck, RJ, Brasil). O xilol é miscível em álcool e em a parafina, isto é, remove todo o álcool das peças anatômicas e fornece ao tecido condições de ser impregnado pela parafina. O tempo de imersão em cada solução de xilol I, II e III dependerá da evolução da diafanização. De modo geral, as peças ficaram em torno de uma hora em cada solução.

Após o xilol substituir todo o álcool nas peças, estas foram submetidas a parafinização lenta, promovida por seguidos banhos de xilol-parafina, nas proporções de 2:1, 2:2, e parafina pura (Reagen, PR, Brasil), sendo que as peças ficaram imersas uma hora em cada banho. Durante este procedimento as peças foram mantidas em estufa de temperatura constante regulada para $58^{\circ} \mathrm{C}$, até que o xilol fosse completamente substituído pela parafina fundida. Os blocos de parafina solidificados foram identificados e colocados em água gelada e, em seguida, no refrigerador, para evitar sua cristalização.

Cortes axiais e longitudinais semi-seriados foram obtidos em micrótomo com espessura de $5 \mu \mathrm{m}$. As fitas foram levadas ao cristalizador (Robertshaw, IL, EUA), onde foram distendidas e montadas em lâminas silanizadas para microscopia (Objektträger - Knittel Gläser, Bielefeld, Alemanha). Posteriormente, estas lâminas foram mantidas em estufa, em posição vertical, por 24 horas, a $40^{\circ} \mathrm{C}$, para que remoção da umidade e aderência do material à lâmina.

Para os cortes serem submetidos à coloração foi realizada a desparafinização das lâminas. Primeiro eliminou-se a parafina dos cortes utilizando-se xilol puro (xilol I, II e III) com duração de 30 minutos por solução. Assim que foi constatada a eliminação da parafina dos cortes, iniciou-se o processo de hidratação. O xilol foi removido com banhos de álcool absoluto e, em seguida, foi utilizado porcentagens decrescentes de soluções de álcoois a $90 \%, 70 \%$ e $40 \%$ e à água destilada. Os cortes permaneceram em cada solução por 3 minutos. A finalidade deste método foi de evitar fenômenos osmóticos bruscos que produziriam retrações e deslocamento do material da lâmina. 
Os cortes hidratados foram submetidos à coloração por hematoxilina (Merck, RJ, Brasil) por 10 minutos. Realizou-se a lavagem das lâminas em água corrente até os tecidos assumirem tom azulado. Em seguida foram mergulhadas rapidamente em solução de ácido clorídrico a $1 \%$ diluído em álcool a $70 \%$. Nova lavagem foi realizada em água corrente por 5 a 10 minutos e foi realizada rapidamente uma passagem em álcool a 95\%. A eosina (Merck, RJ, Brasil) foi utilizada de 1 a 3 minutos, a fim de fornecer aos tecidos a cor rosada. A seguir, foi realizada nova desidratação com porcentagens crescentes de soluções de álcool $(40,60$, 80 e $95 \%$ ) até chegar ao álcool absoluto. As lâminas foram submetidas a dois banhos de xilol. Posteriomente, as lâminas foram cobertas com lamínulas montadas com Entelan (Merck, RJ, Brasil).

\subsection{Avaliação Histológica}

A avaliação histológica foi realizada a fim de se descrever e observar os tipos celulares, o processo de remodelação óssea e o tecido ósseo neoformado na região da sutura palatina mediana. Estes dados posteriormente foram associados à expressão gênica e proteica, a fim de relacionar se o gene e a proteína que foram estimulados ou inibidos nas condições de diabetes e ERM refletiam uma condição de formação ou reabsorção óssea no tecido.

Em microscopia de luz foram feitas as descrições histológicas da expansão maxilar da sutura palatina. Utilizou-se o microscópico Olympus BX61 acoplado à câmera DP72 (Tokio, Japão) e para a captura das imagens foi usado o programa DP2-BSW versão 2.2. Estas avaliações dos espécimes foram feitas em aumentos progressivos da área de interesse.

\subsection{Análise da expressão gênica através da reação da polimerase em cadeia em tempo real (qRT-PCR)}

A fim de entender e esclarecer como o processo de remodelação óssea estava sendo regulado geneticamente no DM1 e na ERM, foi realizada a avaliação da expressão de genes relacionados ao metabolismo ósseo, isto é, quais genes haviam sido transcritos em RNA mensageiro (RNAm).

Inicialmente os espécimes foram pesados para dar sequência às diversas etapas para posterior avaliação da expressão gênica. 
Abaixo estão descritas as etapas e fases até o momento da análise da expressão do RNAm dos diferentes genes de interesse.

\section{a) Extração de RNA total}

Os tecidos coletados da sutura palatina mediana foram agrupados de acordo com o tratamento realizado para a confecção de um pool de amostras. O RNA total foi extraído utilizando-se o Kit RNeasy Mini, que é comercializado com o tampão RLT, tampão RW1 e tampão RPE (Qiagen ${ }^{\circledR}$ Inc., Valencia, CA, EUA). O protocolo de extração utilizou colunas e membranas de sílica e soluções à base de tiocianato de guanidina, que é um tampão biológico para proteína e ácidos nucleicos.

Os tecidos foram pesados e acrescentou-se $350 \mu \mathrm{l}$ ou $600 \mu \mathrm{l}$ de tampão RLT para amostras de tecidos com peso $\leq 20 \mathrm{mg}$ ou para amostras de tecidos com peso $\leq 30 \mathrm{mg}$, respectivamente, de acordo com as instruções recomendadas pelo fabricante. Posteriormente, foi adicionado uma proporção de $10 \mu \mathrm{l}$ de $\beta$-mercaptoetanol para $1000 \mu \mathrm{l}$ de tampão RLT em tubos de 1,5 ml. As amostras foram trituradas, homogeneizadas e colocadas em agitador por 1 minuto. A amostra foi lisada e centrifugada a 10.000 rpm por 3 minutos. Cuidadosamente o sobrenadante foi removido e pipetado em tubos novos.

Acrescentou-se $600 \mu \mathrm{l}$ ou $350 \mu \mathrm{l}$ de álcool a $70 \%$ ao sobrenadante de acordo com o peso inicial das amostras, o qual foi misturado apenas realizando a pipetagem. Este procedimento foi realizado com a finalidade de fornecer condição apropriada para ligação do RNA à coluna de purificação. A seguir $700 \mu \mathrm{l}$ da solução foram transferidos para a coluna acoplada em tubos de $2 \mathrm{ml}$. A coluna foi fechada e uma nova centrifugação foi realizada a 10.000 rpm por 1 minuto. O centrifugado foi reservado para posterior utilização na técnica de Western Blotting, uma vez que este filtrado continha a fração proteica. O conteúdo proteico foi armazenado em freezer a $-20^{\circ} \mathrm{C}$.

Adicionou-se $350 \mu \mathrm{l}$ de tampão RW1 no material que permaneceu na coluna. A solução foi centrifugada a 10.000 rpm por 15 segundos. A seguir diluiu-se a DNase (RnaseFree DNase set, Qiagen ${ }^{\circledR}$ Inc., Valencia, CA, EUA) na proporção de $10 \mu$ para $70 \mu l$ de tampão RDD. Esta solução foi homogeneizada apenas com pipetas. O volume total de $80 \mu$ de DNase diluída ao tampão RDD foi adicionado em cada membrana na coluna de cada amostra e foram incubadas à temperatura ambiente por 15 minutos, a fim de eliminar possível contaminação com DNA genômico. Posteriormente, $350 \mu \mathrm{l}$ de tampão RW1 foram adicionado às colunas e os tubos foram centrifugados a $10.000 \mathrm{rpm}$ por 15 segundos. O filtrado foi descartado.

Adicionou-se $500 \mu \mathrm{l}$ de tampão RPE contendo etanol na coluna e novamente os tubos foram centrifugados a $10.000 \mathrm{rpm}$ por 15 segundos e este filtrado também foi descartado. Acrescentou-se novamente $500 \mu \mathrm{l}$ de tampão RPE contendo etanol à coluna 
colocada em novos tubos coletores de $2 \mathrm{ml}$ e esta solução foi centrifugada a 10.000 rpm durante 2 minutos. O filtrado foi descartado. Realizou-se a centrifugação a 10.000 rpm durante 1 minuto para remover o excesso de etanol na parede externa da coluna.

A coluna foi transferida e acoplada em um tubo eppendorf de $1,5 \mathrm{ml}$. O material presente na membrana da coluna foi eluído em $40 \mu \mathrm{l}$ de água livre de nuclease e nova centrifugação a 10.000 rpm por 1 minuto foi realizada.

Desta maneira o material filtrado que foi obtido nos tubos eppendorfs era o RNA total extraído das amostras, que estava purificado e livre de sais e fragmentos de DNA carregados das reações anteriores.

A integridade do RNA total, obtido após a extração, foi inferida com base na integridade das bandas correspondentes aos RNAs ribossômicos $18 \mathrm{~S}$ e $28 \mathrm{~S}$.

A quantificação e qualidade do RNA total foram analisadas em espectrofotômetro Nanodrop 2000 (Thermo Scientific, Wilmington, DE, EUA). O grau de pureza foi avaliado pela absorbância em espectrofotômetro nos comprimentos de onda de 230nm (detecta presença de fenol e sais), $260 \mathrm{~nm}$ (detecta presença de ácidos nucleicos) e 280nm (detecta presença de proteínas). A quantidade foi obtida através da multiplicação do valor da absorbância a $260 \mathrm{~nm}$ pelo fator 40 , o que permitiu a estimativa da concentração de RNA total em $\mathrm{ng} / \mathrm{ml}$.

A razão A260/280 deve resultar em valores entre 1,8 a 2,1, a fim de mostrar que não houve contaminação do RNA por proteínas. Por outro lado, a razão A260/230 deve mostrar valores acima de 1,7, resultados que mostraram que não houve contaminação com guanidina e/ou fenóis ou outros sais provenientes durante processo de extração. Estas razões e a quantidade de RNA total foram calculadas, assim como a sua integridade foi avaliada em gel de agarose através da marcação das bandas ribossômicas de interesse. Todos os dados obtidos para o RNA total estavam dentro das exigências para que fosse possível a sua posterior utilização em outras etapas.

O RNA total foi armazenado a $-80^{\circ} \mathrm{C}$ para posterior confecção do DNA complementar (DNAc).

\section{b) Transcrição Reversa - Síntese e obtenção do DNA complementar}

A síntese do DNAc foi obtida a partir do RNA total através da reação de transcrição reversa. Utilizou-se nesta etapa o kit High Capacity cDNA Reverse Transcription (Applied Biosystems $^{\circledR}$, Foster City, CA, EUA) de acordo com o protocolo descrito pelo fabricante.

As amostras armazenadas em freezer a $-80^{\circ} \mathrm{C}$ foram descongeladas e mantidas em gelo. Novos tubos eppendorfs de $0,1 \mathrm{ml}$ foram preparados com suas respectivas identificações para transcrição do DNAc. 
O DNAc foi sintetizado utilizando-se $2 \mu \mathrm{g}$ de RNA total de cada amostra. Adicionouse às amostras a quantidade recomendada pelo fabricante de cada componente do kit High Capacity cDNA Reverse Transcription (tampão RT, dNTP mix, primers, Multiscribe ${ }^{\mathrm{TM}}$ transcriptase reversa e água livre de nuclease) para obtenção de um volume final de $40 \mu \mathrm{l}$, para a realização da reação de transcrição reversa. A reação foi realizada em termociclador Veriti (Applied Biosystems ${ }^{\circledR}$, Foster City, CA, EUA). As amostras foram colocadas em placas adaptadas para termociclador programado para atingir as condições de ciclagem recomendadas pelo fabricante. As amostras foram incubadas a $25^{\circ} \mathrm{C}$ por 10 minutos para ligação do primer ao RNA, seguida de incubação a $37^{\circ} \mathrm{C}$ por 2 horas para transcrição reversa, utilizando a enzima transcriptase reversa, e posterior incubação a $85^{\circ} \mathrm{C}$ por 5 segundos para inativação da enzima e finalização do processo.

Após a obtenção do DNAc, as amostras foram estocadas em freezer a $-20^{\circ} \mathrm{C}$ até a realização do qRT-PCR.

\section{c) Reação em Cadeia da Polimerase (PCR) após Transcrição Reversa ou PCR em tempo real (qRT-PCR)}

A reação da polimerase em cadeia tem por objetivo amplificar os cDNAs provenientes das diferentes amostras, obtendo amplicons (segmentos de DNAc gerado pelo processo de PCR) em escala exponencial.

Os cDNAs dos genes de interesse Osteoprotegerina (Opg), Tnfrsf11a (Rank) Tnfsf11 (Rankl), Bglap (Osteocalcina), Sparc (Osteonectina - Opn), Bmp2 (Proteína Óssea Morfogenética 2), Ibsp (Sialoproteína Óssea - Bsp) e Spp1 (Osteopontina - Opn) e o gene constitutivo Beta-actina (Actb) foram amplificados em aparelho para PCR em tempo real. As leituras de fluorescência foram realizadas pelo equipamento StepOne Plus (Applied Biosystems $^{\circledR}$, Foster City, CA, EUA). A $\beta$-actina foi utilizada como gene de referência, a água destilada deionizada como controle negativo e RNA de uma das amostras foi adicionada aos primers ao invés de cDNA, para confirmar ausência de DNA genômico para os experimentos da reação de qRT-PCR.

As amplificações por PCR foram realizadas em duplicata utilizando placas de 96 poços. Para as reações de qRT-PCR foram utilizadas alíquotas de $10 \mathrm{ng}$ de DNAc de cada amostra, que foram adicionadas à $10 \mu \mathrm{l}$ de $\operatorname{Taqman}^{\circledR}$ Gene Expression Master Mix (Applied Biosystems $^{\circledR}$, Foster City, CA, EUA), $1 \mu \mathrm{l}$ de TaqMan $^{\circledR}$ Gene Expression Assays (primers e sondas específicos para cada gene de interesse) (Applied Biosystems ${ }^{\circledR}$, Foster City, CA, EUA), acrescido de quantidade necessária de água livre de RNAse para obtenção de uma solução com volume final de $20 \mu \mathrm{l}$ por poço. 
Os primers e sondas do sistema TaqMan ${ }^{\circledR}$ Gene Expression Assays foram obtidos cormercialmente e por serem propriedades privadas, as sequências não estão disponíveis. Os primers e sondas selecionados foram Tnfrsf11b (Opg - Rn00563499_m1), Tnfrsf11a (Rank-Rn01426423_m1), Tnfsf11 (Rankl-Rn00589289_m1), Bglap (Occ-Rn00566386_g1), Sparc (Onc - Rn01470624_m1), Bmp2 (Bmp2 - Rn00567818_m1), Ibsp (Bsp Rn00561414_m1) e Spp1 (Opn - Rn01449972_m1) e o gene de referência Beta-actina (Actb - Rn00667869_m1).

Posteriormente, montou-se o layout das placas para as reações de qRT-PCR serem lidas no aparelho StepOne Plus ${ }^{\circledR}$ (Applied Biosystems ${ }^{\circledR}$, Foster City, CA, EUA), que realiza as reações de amplificação e detecção. Colocou-se $20 \mu \mathrm{l}$ das diferentes amostras em cada poço da placa. As condições de amplificação das diferentes etapas da reação de qRT-PCR foram realizadas de acordo com as recomendações de tempo e temperatura propostas pelo fabricante (estágio $1: 95^{\circ} \mathrm{C}$ por 10 minutos para ativação da polimerase, estágio 2: 40 ciclos cada um com temperatura de $95^{\circ} \mathrm{C}$ por 15 segundos para desnaturação do DNA e $60^{\circ} \mathrm{C}$ por 1 minuto para anelamento do primer e polimerização).

Os dados foram analisados no software StepOne ${ }^{\mathrm{TM}}$ versão 2.3. Todas as reações foram submetidas às mesmas condições de análise e normalizadas pelo sinal do corante de referência passiva ROX para correção de flutuações na leitura não relacionadas à PCR, ou seja, flutuações decorrentes das variações de volume e evaporação ao longo da reação de PCR. Este programa quantifica as amostras por meio da análise da quantidade de fluorescência gerada pela liberação do fluoróforo 6-FAM aos produtos de amplificação durante o curso da reação de PCR. Neste sistema, o fluoróforo 6-FAM foi utilizado como repórter na sonda Taqman. A liberação do fluoróforo acontece quando a enzima Taq DNA polimerase promove a extensão do primer e sintetiza a fita nascente de DNAc. Esta enzima apresenta atividade exonuclease 5', que degrada a sonda que esta anelada à fita de cDNA. A degradação da sonda permite a liberação do fluoróforo (repórter), que emite o sinal fluorescente na cor azul (comprimento de onda de $495 \mathrm{~nm}$ a $521 \mathrm{~nm}$ ).

Os resultados foram analisados com base no valor do ciclo limiar ( $\mathrm{Ct}$ - cycle threshold), sendo este o ponto correspondente ao número de ciclos de amplificação necessários para que o sinal fluorescente atinja o limiar de detecção para determinado número de cópias. Este limiar é determinado entre o grau de fluorescência dos controles negativos e a fase de amplificação exponencial das amostras que permite a análise quantitativa da expressão do gene avaliado. Para normalizar os valores de $\mathrm{Ct}$, de forma a considerar diferenças causadas por quantidades distintas de DNAc utilizadas nas reações, o Ct determinado para uma amostra foi subtraído do Ct do gene de referência da mesma amostra, gerando assim o $\Delta$ Ct. Para cada gene, o cálculo de expressão relativa foi realizado 
a partir da diferença entre $\Delta \mathrm{Ct}$ das amostras e o $\Delta \mathrm{Ct}$ apresentado pelo controle $(\Delta \Delta \mathrm{Ct})$, com base na expressão do gene de referência.

A seguir foi calculado o $\Delta \Delta$ Ct considerando como calibrador o grupo controle (C), no período de 3 dias. O cálculo $\Delta \Delta$ Ct baseado na reação exponencial da PCR foi obtido a partir da expressão $Q R=2^{-\Delta \Delta C t}$, no qual $Q R$ representa o nível de expressão gênica relativa, $C t$ o ciclo de amplificação na qual cada amostra apresenta amplificação exponencial, $\Delta \mathrm{Ct}$ se refere a diferença entre $\mathrm{Ct}$ da amostra amplificada para o gene alvo e o Ct da mesma amostra amplificada para o gene de referência e $\Delta \Delta \mathrm{Ct}$ representa a diferença entre o $\Delta \mathrm{Ct}$ da amostra de interesse e o $\Delta \mathrm{Ct}$ da amostra $\mathrm{C}$. A quantificação relativa foi utilizada para analisar alterações na expressão gênica em uma determinada amostra relativa à outra amostra de referência, isto é, uma amostra controle não tratada. Os cálculos estão descritos suscintamente na fórmula aritmética abaixo.

$\Delta \mathrm{Ct}=\mathrm{Ct}$ gene alvo- $\mathrm{Ct}$ gene de referência

$\Delta \Delta \mathrm{Ct}=(\mathrm{Ct}$ gene alvo $-\mathrm{Ct}$ gene de referência) amostra - (Ct gene alvo - Ct gene de referência) calibrador

Expressão Relativa $(\mathrm{QR})=2^{-\Delta \Delta C t}$

\subsection{Análise proteica através da técnica de Western Blotting}

A avaliação proteica através da técnica de Western Blotting (WB) foi escolhida para investigar se a estimulação gênica correspondia com a produção de proteínas envolvidas no processo de remodelação óssea em animais com DM1 e submetidos à ERM.

A proteína total foi obtida durante os passos técnicos da extração do RNAt para a técnica de qRT-PCR. O filtrado com a fração proteica que estava estocado em freezer $\mathrm{a}-20^{\circ} \mathrm{C}$ foi descongelado para utilização na técnica de WB.

Utilizou-se para as etapas iniciais o Kit Bolt ${ }^{\mathrm{TM}}$ (Novex, Life Technologies, Carlsbad, CA, EUA) que continha o tampão de amostra (4x) (LDS Sample Buffer - ref. B0007) e agente de redução de amostra (10x) (Sample Reducing Agent ref. B0009). Para a etapa de eletroforese utilizou-se o tampão de corrida Bolt ${ }^{T M}$ MES SDS Running Buffer [20x] (Novex, Life Technologies, Carlsbad, CA, EUA). As amostras foram separadas pelo sistema SDSPAGE (Sodium Dodecyl Sulfate Polyacrylamide Gel Electrophoresis) em géis de corrida de 
poliacrilamida de 4 a 12\% (Bolt ${ }^{\mathrm{TM}}$ Mini Gels Bis Tris 10 well 4-12\% - Novex, Life Technologies, Carlsbad, CA, EUA), sendo a concentração de poliacrilamida escolhida de acordo com o peso molecular das proteínas de interesse. O marcador de peso molecular See Blue ${ }^{\circledR}$ Plus2 PreStained Standard (Novex, Life Technologies, Carlsbad, CA, EUA) foi utilizado como referência. As etapas do WB foram descritas minuciosamente abaixo.

Inicialmente foi feita a quantificação da proteína total pelo método de Lowry, porém não foi possível realizar a técnica de WB utilizando quantidades semelhantes de proteínas de cada amostra obtidas através deste método devido à dificuldade de resuspensão do pellet obtido. Desta maneira, solucionamos o problema padronizando a técnica utilizando pesos semelhantes dos precipitados (pellet) das amostras.

As amostras foram descongeladas e o sobrenadante contido nos tubos eppendorf foi removido e descartado. Os precipitados foram pesados para obtenção de amostras com o mesmo peso.

Previamente à realização do sistema SDS-PAGE, o precipitado foi tratado utilizando o protocolo de remoção de guanidina (Wessel e Flugge, 1984). A guanidina é uma substância proveniente das etapas de extração do RNA. Este protocolo consistiu do tratamento do pellet com etanol para precipitar proteínas.

Para cada volume de amostra, foi adicionado 9 volumes de etanol a $100 \%$ previamente resfriado em freezer a $-20^{\circ} \mathrm{C}$. As soluções foram agitadas em vórtex por um minuto em velocidade máxima e deixadas para descansar em freezer a $-20^{\circ} \mathrm{C}$ por 1 hora. Após 1 hora, as soluções foram centrifugadas por 15 minutos em microcentrífuga (Centrífuga Micro mod 243, Fanem ${ }^{\circledR}$, São Paulo, SP, Brasil) na velocidade máxima.

O pellet foi mantido e o sobrenadante foi cuidadosamente descartado. O pellet foi lavado com etanol a $90 \%$ previamente resfriado em freezer a $-20^{\circ} \mathrm{C}$. As amostras em etanol a $90 \%$ foram agitadas em vórtex (MS3 digital, IKA ${ }^{\circledR}, N Y$, EUA) e centrifugadas por 5 minutos em velocidade máxima. $O$ sobrenadante foi descartado e posteriormente as amostras foram levadas para secar a vácuo (Concentrator Plus, Eppendorf AG, Hamburg, Alemanha) por 30 minutos a $45^{\circ} \mathrm{C}$ para eliminar resíduos de etanol. Com este protocolo foi possível dar continuidade à técnica de WB, uma vez que as bandas ficariam mais uniformes e passíveis de comparações.

Os precipitados obtidos após a realização do protocolo de remoção de guanidina, foram resuspensos em tampão de amostra LDS [4x] do Kit Bolt. Em cada tubo foi colocado quantidade de tampão LDS semelhante ao peso do precipitado, $8 \mu \mathrm{l}$ de agente de redução da amostra [10x] e foi adicionado $32 \mu \mathrm{l}$ de água Milli $Q$. As amostras foram agitadas por 1 minuto em vórtex na velocidade máxima. Posteriormente as amostras foram aquecidas à $70^{\circ} \mathrm{C} \mathrm{em}$ banho seco (Dry Bath incubator, Genius, Major Science, Pan-Chiao City, Taipei Hsien, 
Taiwan) por 10 minutos. As amostras contidas nos tubos foram centrifugadas a $7.000 \mathrm{rpm}$ por 30 segundos.

O tampão de corrida [Bolt MES SDS (20x)] foi preparado em uma proveta, onde foi colocado $380 \mathrm{ml}$ de água Milli $\mathrm{Q}$ e adicionados $20 \mathrm{ml}$ do tampão de corrida. A solução foi misturada e colocada na câmara do tanque de eletroforese (Bolt Mini Blot Module - ref. B1000) até atingir cada eletrodo.

O gel de corrida foi posicionado na câmara do tanque de eletroforese. No primeiro poço foi pipetado $5 \mu$ d do marcador See Blue ${ }^{\circledR}$ Plus2 Pre-Stained Standard e nos outros poços do gel foram pipetados $10 \mu \mathrm{l}$ de cada amostra em tampão LDS. Os tanques foram fechados e a fonte de eletroforese foi ligada na voltagem de $120 \mathrm{~V}$ constante.

Após a separação das proteínas de acordo com o peso molecular, as mesmas foram eletroforeticamente transferidas para membranas de fluoreto de polivinilideno (PVDF) (Imobilon $^{\mathrm{TM}}$-P; Millipore, Billerica, Carlsbad, CA, EUA), usando como solução tampão de transferência $25 \mathrm{ml}$ de Bolt Transfer Buffer [20x] (Novex, Life Technologies, Carlsbad, CA, EUA), $50 \mathrm{ml}$ de metanol e $425 \mathrm{ml}$ de água Milli Q. O gel foi removido do tanque de eletroforese, foi recortado e lavado em água Milli Q. Durante a lavagem do gel, o sistema de transferência semi-úmido (Trans Blot Turbo ${ }^{\mathrm{TM}}$ Transfer System, Bio Rad Inc., Hercules, CA, EUA) foi preparado. No cassete do sistema de transferência foi montada a seguinte sequência de

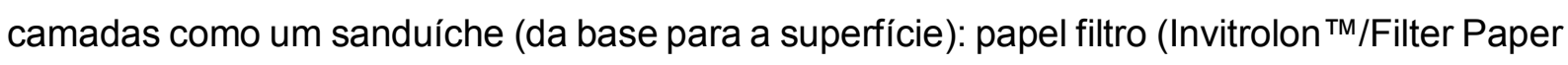
Sandwich, Invitrogen, Life Technologies, Carlsbad, CA, EUA) umedecido na solução de transferência, membrana umedecida em metanol por 30 segundos e umedecida em solução de transferência, gel umedecido no tampão de transferência, papel filtro umedecido na solução de transferência. Em cada camada foram removidas as bolhas de ar. $\mathrm{O}$ cassete foi lacrado e colocado no sistema de transferência à $25 \mathrm{~V}$ e $1 \mathrm{~A}$ por 30 minutos.

Durante a transferência foi preparado $50 \mathrm{ml}$ da solução de Bloqueio a $5 \%[0,5 \mathrm{~g}$ de albumina do soro bovino - BSA em $10 \mathrm{ml}$ de Tris Buffer Solution - Tween 0,01\% - TBS-T (1x)] em tubo Falcon. Após a transferência a membrana foi hidratada em água Milli $Q$ e agitada por um minuto. Posteriormente, a água Milli $Q$ foi removida e adicionou-se $10 \mathrm{ml}$ da solução de bloqueio. Os sítios de ligação não-específicos foram bloqueados em solução de bloqueio por 1 hora em constante agitação.

Durante o tempo de bloqueio da membrana, foi preparado em tubo falcon $50 \mu \mathrm{l}$ de anticorpo primário de cada proteína de interesse em $10 \mathrm{ml}$ da solução de bloqueio a $5 \%$. As informações de cada anticorpo primário sobre a concentração, peso molecular e animal de origem foram obtidos através dos manuais disponibilizados pelo fabricante. Os anticorpos selecionados foram osteoprotegerina - OPG (concentração: 1:200, peso molecular: 60 kDa monômero/ 120kDa homodímero, animal de origem: cabra, policlonal, N-20, sc8468; Santa Cruz Biotechnology Inc., Dallas, TX, EUA), RANK (concentração: 1:200, peso molecular 90 
kDa, animal de origem: cabra, policlonal, N-20, sc7626, Santa Cruz Biotechnology Inc., Dallas, TX, EUA), RANKL (concentração: 1:200, peso molecular: 35-40 kDa forma ligada à membrana/ 20-30kDa forma solúvel, animal de origem: cabra, policlonal, N-19, sc7628; Santa Cruz Biotechnology Inc., Dallas, TX, EUA), osteocalcina - OCC (concentração: 1:200, peso molecular: $6 \mathrm{kDa}$, animal de origem: coelho, policlonal, FL-95, sc-30045; Santa Cruz Biotechnology Inc., Dallas, TX, EUA), osteonectina - ONC (concentração: 1:200, 43 kDa, animal de origem: coelho, policlonal, H-90, sc25574, Santa Cruz Biotechnology Inc., Dallas, TX, EUA), BMP2 (concentração: 1:200, peso molecular: $60 \mathrm{kDa}$ precursor/ 30kDa homodímero/ 18kDa monômero, animal de origem: cabra, policlonal, N-14, sc6895, Santa Cruz Biotechnology Inc., Dallas, TX, EUA), sialoproteína óssea - BSPII (concentração: 1:200, peso molecular: $35 \mathrm{kDa}$, animal de origem: coelho, policlonal, M-154, sc-292394, Santa Cruz Biotechnology Inc., Dallas, TX, EUA), osteopontina - OPN (concentração: 1:200, peso molecular: $66 \mathrm{kDa}$ precursor/ 25-55kDa produto clivado, animal de origem: camundongo, monoclonal, LFMb-14, sc-73631, Santa Cruz Biotechnology Inc., Dallas, TX, EUA) e anticorpo primário para Beta-Actina - ACTB (concentração: 1:200, peso molecular: 43 kDa/ 15kDa região terminal $\mathrm{C}$, animal de origem: camundongo, monoclonal, ACTBD11B7, sc-81178; Santa Cruz Biotechnology Inc., Dallas, TX, EUA).

Após uma hora de bloqueio, as membranas foram incubadas com os diferentes anticorpos primários de interesse durante 12 horas (overnight) sob constante agitação. Após a incubação com o anticorpo primário, as membranas foram lavadas em TBST-T por 10 minutos $(3 x)$ e em seguida foram incubadas com os seus respectivos anticorpos secundários.

Os anticorpos secundários, específicos contra o animal de origem do anticorpo primário, foram selecionados e preparados durante a incubação da membrana com o anticorpo primário. Foram utilizados anticorpos secundários contra Imunoglobulina $G$ de camundongo, cabra ou coelho conjugados à horseradish peroxidase (Santa Cruz Biotechnology Inc., Dallas, TX, EUA) dissolvidos em $10 \mathrm{ml}$ da solução de bloqueio, durante 40 minutos, sob constante agitação, à temperatura ambiente, utilizando concentrações padronizadas de acordo com as referências abaixo.

Os anticorpos secundários foram obtidos comercialmente com as seguintes referências: goat anti-rabbit IgG-HRP (concentração: 1:5000, sc-2054, Santa Cruz Biotechnology Inc., Dallas, TX, EUA), rabbit anti-mouse IgG-HRP (concentração: 1:2000, sc358920, Santa Cruz Biotechnology Inc., Dallas, TX, EUA) e rabbit anti-goat IgG-HRP (concentração: 1:500, sc-2768, Santa Cruz Biotechnology Inc., Dallas, TX, EUA).

Após a incubação com o anticorpo secundário, as membranas foram novamente lavadas com TBS-T por 10 minutos (3x) e em seguida lavadas e agitadas em água Milli $Q$ por 2 minutos. Após a lavagem, as bandas foram evidenciadas por quimioluminescência utilizando o sistema de detecção HRP Quimiluminescent Substrate Reagent (W.P20005, Novex, ECL 
Invitrogen, Life Technologies, Carlsbad, CA, EUA). Em cada membrana foi colocado o substrato quimioluminescente $\left(0,06 \mathrm{ml} / \mathrm{cm}^{2}\right.$ da membrana para cada reagente $A$ e $\left.B\right)$ em constante agitação por 1 minuto. Posteriormente, as membranas foram submetidas à exposição por 2 minutos, utilizando o fotodocumentador de captura UVITEC Alliance Mini 2 (Alliance-LD2-87.WL, Cambrige, Reino Unido).

As imagens digitalizadas mostraram bandas uniformes sem deformações, com possibilidade de comparação entre os diferentes grupos e análise das diversas proteínas de interesse. As proteínas marcadas nas bandas foram comparadas através da análise densitométrica (relação entre pixels e a área da banda) utilizando o programa Image J $1.48 \mathrm{v}$ (programa de domínio público desenvolvido por Wayne Rasband, Research Service Branch, $\mathrm{NIH}$, Maryland, EUA)

\subsection{Análise Estatística}

Os resultados foram analisados estatisticamente no software GraphPad Prism 6.

Os dados obtidos durante as avaliações clínicas (peso, consumo hídrico e glicemia), nas reações de qRT-PCR para os diferentes gene e no Western Blotting para cada proteína de interesse foram submetidos ao teste estatístico ANOVA de duas vias e pós-teste de Tukey. O nível de significância adotado foi de $5 \%(\alpha=0,05)$. 


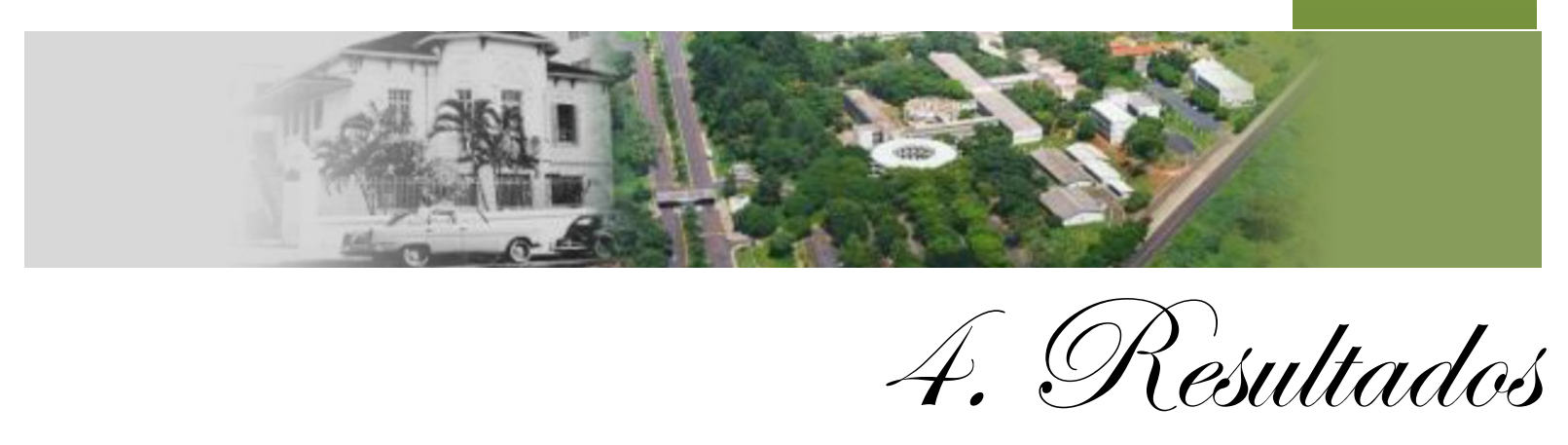




\section{RESULTADOS}

\subsection{Radiografias}

Na radiografia dos grupos sem disjunção obteve-se a imagem de três molares e um incisivo central em cada hemi-arcada, presença de pontos de contatos proximais entre incisivos e entre molares, assim como a presença da sutura palatina mediana. A lâmina dura caracterizou-se por linhas radiopacas definidas, uniformes e equidistantes das bordas da sutura. O osso trabecular apresentou aparência normal caracterizada pela imagem alternada de áreas radiolúcidas e finos tabiques radiopacos. As coroas dos incisivos superiores estavam em contato e mostravam paralelismo de raiz (Figura 4).

Por outro lado, na radiografia dos grupos submetidos à disjunção, obteve-se uma imagem com a presença dos molares, o aparelho entre os incisivos centrais e a confirmação da abertura da sutura palatina mediana. Neste exame radiográfico foi visualizado um espaço radiolúcido, definido, largo em formato da consoante $\mathrm{V}$, nítido e bem uniforme na região anterior (entre os incisivos centrais) em direção a região posterior (molares). Além disso, podese observar que as características da lâmina dura e do osso trabecular foram semelhantes aos animais que não foram submetidos à disjunção (Figura 5).
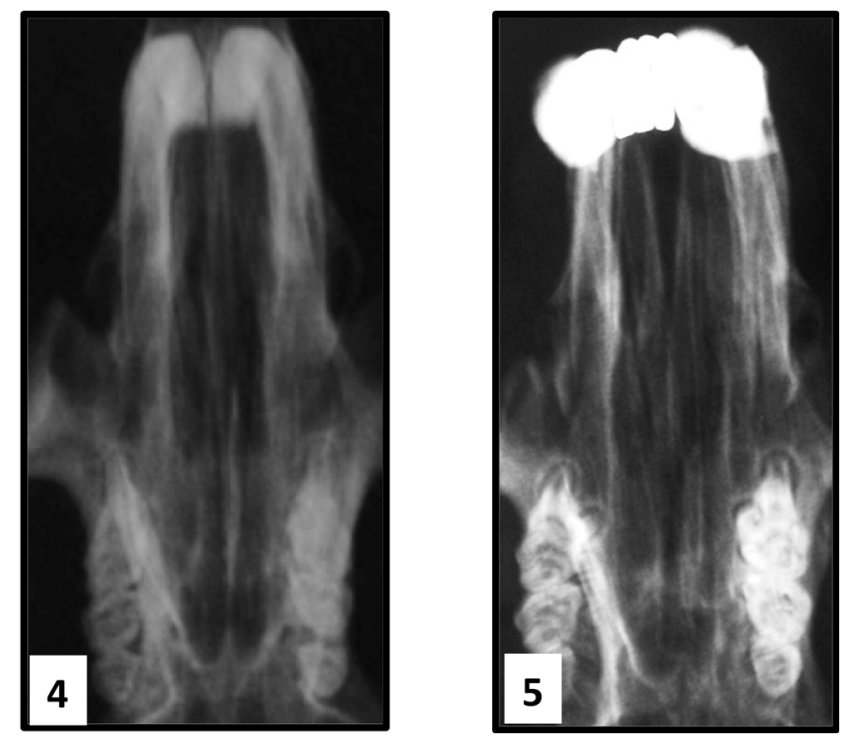

Figura 4: Radiografia da sutura palatina mediana intacta.

Figura 5: Radiografia de confirmação da abertura da sutura palatina mediana após disjunção e instalação do aparelho. 


\subsection{Avaliações Clínicas}

Durante avaliação clínica, pode-se notar que em todos os animais sem disjunção a gengiva marginal livre apresentava-se sadia, sem sinais clínicos de inflamação ou ulceração. Além disso, não se observou separação dos pontos de contato entre os incisivos centrais, apenas na região cervical, onde estava presente a papila interdental, achados clínicos que foram confirmados na avaliação histológica.

Nos animais submetidos à disjunção, após a remoção do aparelho ortodôntico que estava fixado nos incisivos centrais superiores, observou-se a demarcação do grampo sobre a mucosa fina, sem áreas de ulceração, porém com a presença de leve hiperplasia gengival. Além disso, pode-se notar clinicamente a separação do ponto de contato entre os incisivos superiores. Estes resultados foram confirmados pelos exames histológicos e radiográficos.

\section{a) Peso}

Ao comparar os grupos $\mathrm{C} \times \mathrm{D}$, observou-se diferença estatisticamente significante no peso dos animais nos períodos de 28 dias de avaliação e nos períodos de 3, 7 e 10 dias de eutanásia $(p<0,05)$, isto é os animais diabéticos perderam peso durante o estudo, ao passo que os animais do grupo controle tiveram um ganho de peso durante os tempos de avaliação. Este mesmo padrão de resultado foi observado quando se comparou os grupos $V \times D, C d x$ $D d$ e $V d x \operatorname{Dd}(p<0,05)$. Por outro lado, não houve diferença estatística entre os pesos dos animais $C \times V, C \times C d, V \times V d, C d x \vee d$ e $D \times D d(p>0,05)$, isto é, os animais do grupo controle e veículo, assim como os animais dos demais grupos submetidos ou não à disjunção apresentaram pesos similares durante todo o desenvolvimento da pesquisa.

Em resumo os animais dos grupos não diabéticos submetidos ou não à disjunção ganharam peso $(p<0,05)$ nos tempo de 28 dias e nos períodos de 3,7 e 10 dias de eutanásia, porém, os animais diabéticos com ou sem disjunção perderam peso nestes períodos $(p<0,05)$ (Figura 6). 


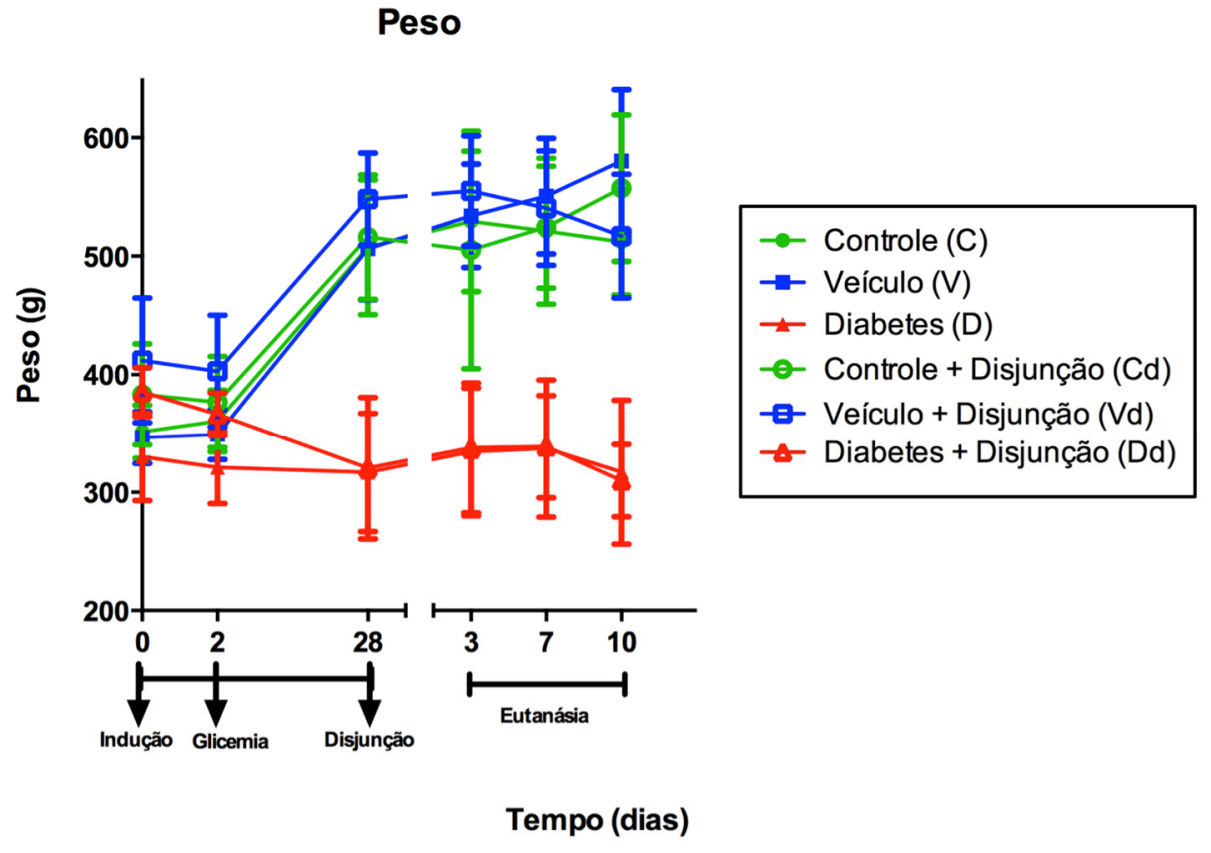

Figura 6: Avaliação do peso (g) nos diferentes grupos de estudo e tempos de avaliação.

\section{b) Consumo Hídrico}

Avaliando-se o consumo hídrico dos animais observou-se diferença estatística quando se comparou os grupos $C \times D, V \times D, C d \times D d$ e $V d \times D d$ após 2 e 28 dias da indução ao diabetes e nos períodos de 3, 7 e 10 dias após a instalação dos aparelhos ortodônticos $(p<0,05)$, isto é os grupos diabéticos com ou sem disjunção apresentaram maior consumo de água comparado aos grupos controles. Para os grupos $\mathrm{D} \times \mathrm{Dd}$ observou-se maior consumo de água nos animais do grupo $D$ nos tempos de 28 dias de validação e 7 dias de eutanásia $(p<0,05)$. Entretanto não se observou diferença no consumo hídrico dos animais do grupo $\mathrm{C}$ $x \vee, C \times C d, \vee x \vee d$ e Cd x Vd $(p>0,05)$ (Figura 7). 


\section{Consumo Hídrico}

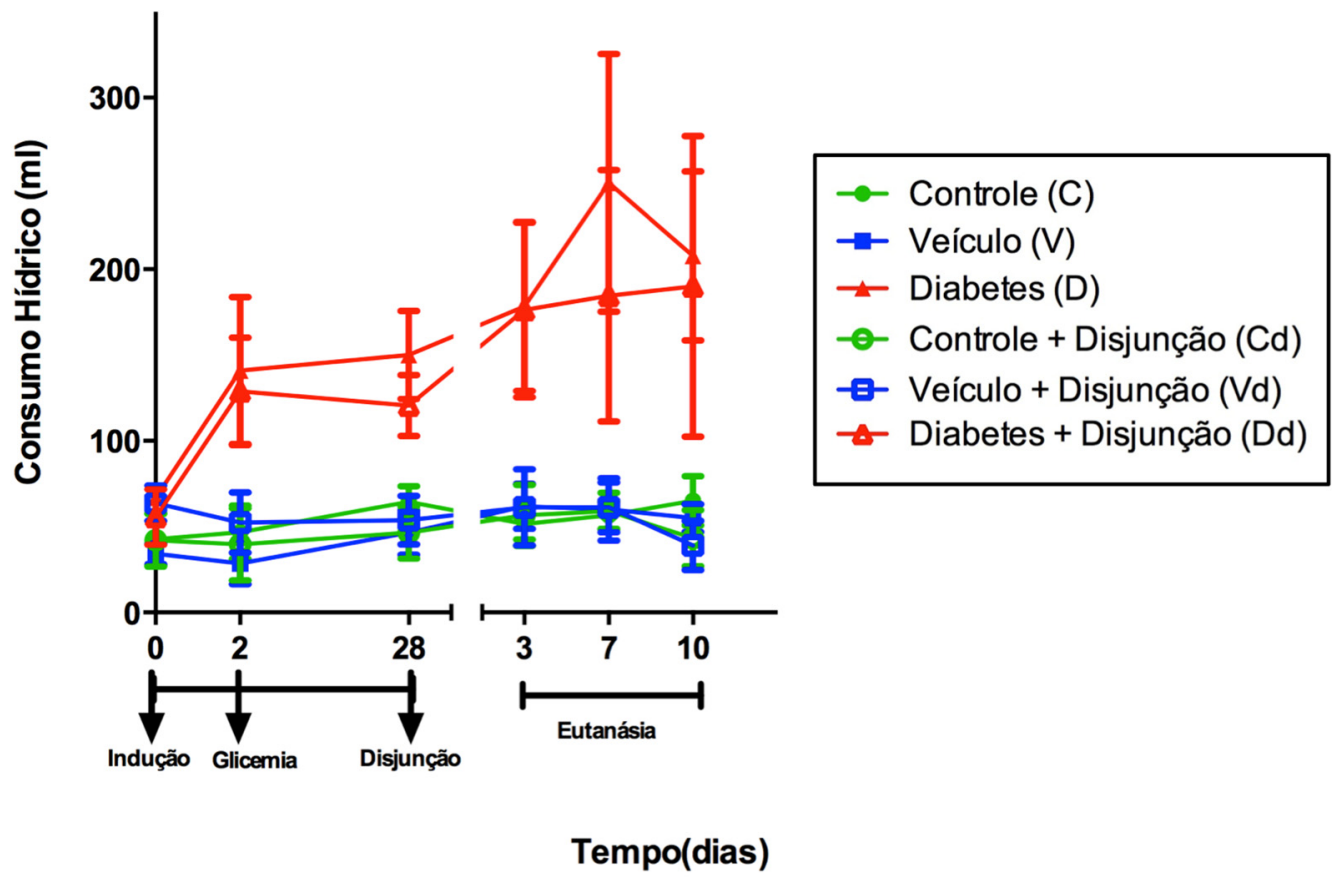

Figura 7: Avaliação do consumo hídrico $(\mathrm{ml})$ nos diferentes grupos de estudo e tempos de avaliação.

\section{c) Glicemia}

Os valores glicêmicos foram estatisticamente diferentes quando se comparou os grupos C x D, V x D, Cd x Dd e Vd x Dd após 2 e 28 dias da indução ao diabetes e nos períodos de 3, 7 e 10 dias após a instalação dos aparelhos ortodônticos $(p<0,05)$, isto é os grupos diabéticos com ou sem disjunção apresentaram níveis glicêmicos mais elevados comparado aos grupos controles. Entretanto não se observou diferença nos índices glicêmicos no grupo C comparado ao grupo V, C x Cd, V x Vd, Cd x Vd e D x Dd $(p>0,05)$ (Figura 8). 


\section{Glicemia}

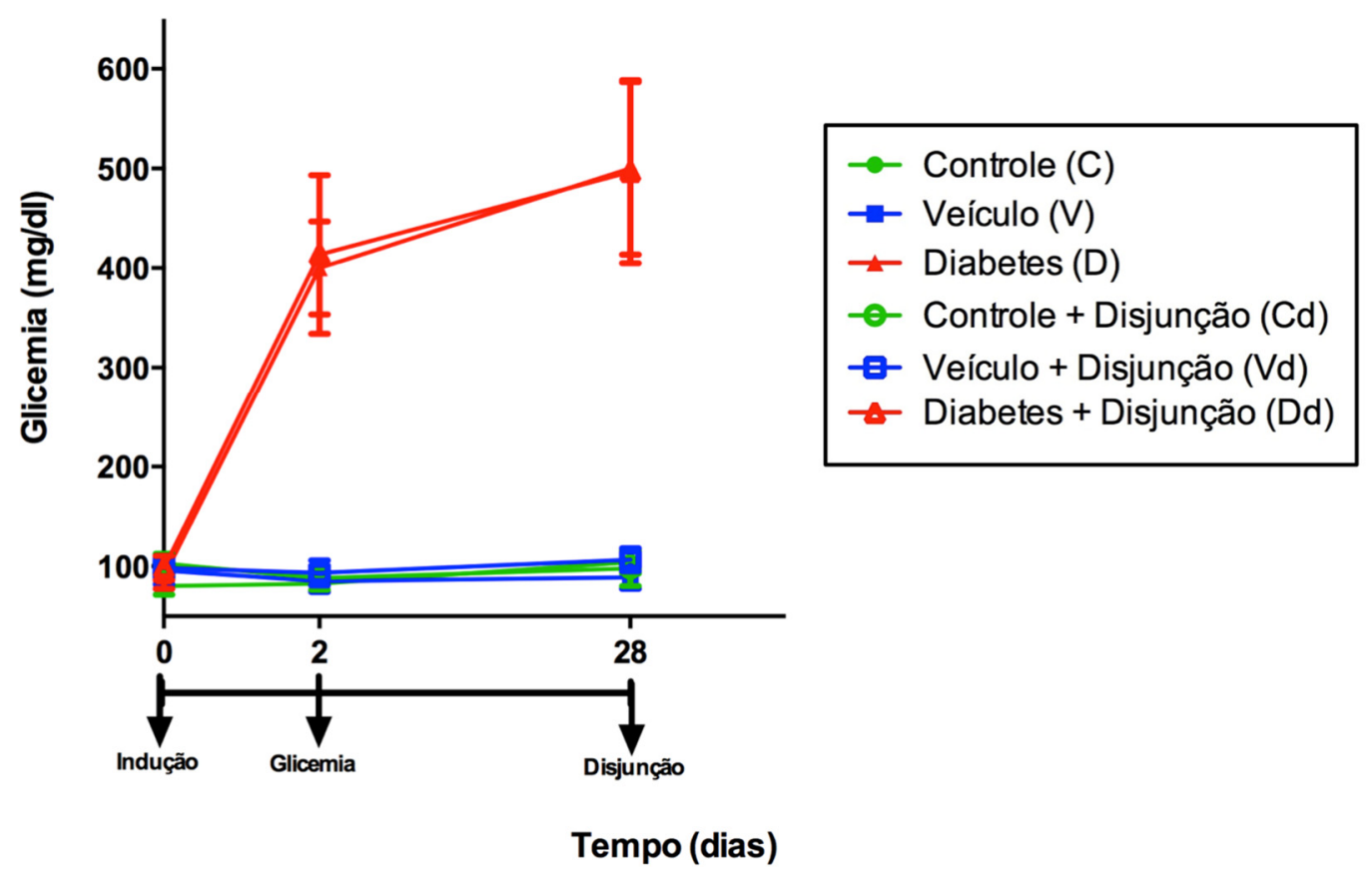

Figura 8: Avaliação glicêmica (mg/dl) nos diferentes grupos de estudo e tempos de avaliação.

Visto que nas avaliações clínicas, os animais dos grupos $\mathrm{C}$ e $\mathrm{V}$ submetidos ou não à disjunção não apresentaram diferença estatística, os experimentos de qRT-PCR e Western Blotting foram realizados usando o grupo $\mathrm{C}$ como grupo de referência para valores basais.

\subsection{Histologia}

Analisaram-se cortes histológicos semi-seriados, longitudinais e frontais da sutura palatina mediana de todos os animais da amostra. Em cada lâmina preparada, pode-se observar a sutura palatina mediana em toda a sua extensão, desde a região dos incisivos centrais até a região dos molares. O modelo de aparelho instalado promoveu a abertura da sutura (em formato da consoante $\mathrm{V}$ ) até a porção média da maxila e início da região posterior, ao nível das superfícies mesiais dos primeiros molares. Desta maneira, serão descritos os aspectos histológicos relacionados a essas regiões específicas, cujas fibras sofreram tração durante o processo de disjunção. 


\subsubsection{Grupos sem disjunção maxilar (C, V e D)}

Estes grupos compreenderam os animais com a sutura intacta C, V e D. O exame histológico das estruturas (fibras, células, tecido conjuntivo, tecido ósseo e vasos sanguíneos) da região da sutura palatina mediana destes animais, mostrou características histológicas compatíveis com a normalidade, isto é, aspectos de remodelação óssea fisiológica. Estas avaliações serviram como base para comparação com os animais dos grupos submetidos à disjunção (Cd, Vd e Dd).

As características histológicas foram semelhantes em todos os grupos sem disjunção nos diferentes períodos, apenas com algumas particularidades observadas nos grupos diabéticos. Estes achados histológicos serão mencionadas adiante.

A superfície óssea sutural nos animais sem disjunção apresentou-se regular, organizada, ligeiramente ondulada e lisa em todo o seu contorno, exceto quando da presença da irrigação proveniente dos espaços medulares subjacentes, que penetravam na região da sutura como perfurações na superfície óssea. Recobrindo ao longo dessa superfície óssea, verificou-se uma fina camada de tecido osteóide com presença de osteoblastos em repouso, caracterizados pela morfologia achatada com núcleos paralelos à superfície óssea e pouco evidentes. Além disso, notou-se alguns osteoblastos ativos, caracterizados como células grandes e arredondadas com núcleos cuboides, volumosos e de coloração mais clara, enfileirados na superfície do tecido osteóide. Estes osteoblastos geralmente se apresentavam de maneira organizada com intensa atividade de síntese.

O espaço sutural apresentou uma espessura uniforme em toda sua extensão. $O$ tecido conjuntivo sutural caracterizou-se por ser um tecido fibroso, rico em fibroblasto e em fibras colágenas e com presença de capilares em toda sua extensão. Os fibroblastos caracterizaram-se por possuírem núcleo ovóide, claro e com nucléolo evidente. Na região anterior da sutura, os feixes de fibras colágenas inseridos no osso (fibras de Sharpey) eram espessos, com orientações perpendiculares ou oblíquos à superfície da sutura. No terço médio da sutura, observou-se feixes de fibras com orientações variadas e sagitais, que se misturavam com o tecido conjuntivo gengival. Na região posterior da sutura, essas fibras colágenas se estenderam de uma superfície à outra do osso, de tal forma que foi possível verificar a nítida conexão entre as bordas da sutura. Ainda nesta região, notou-se numerosos fibrócitos, poucos fibroblastos e fibras colágenas delgadas sem orientação definida. Na região do centro da sutura, a maioria das fibras estavam inseridas perpendicularmente ao osso e projetavam-se para o centro do espaço sutural nas mais diversas direções, formando um emaranhado de fibras. 
Os vasos sanguíneos, geralmente, seguiram a orientação dos feixes de fibras colágenas. O lúmen vascular era circular ou levemente ovalado e alguns vasos estavam repletos de células sanguíneas.

No osso da pré-maxila pode-se observar cavidades medulares e canais de Havers na sua porção lateral. Na sua porção medial, as trabéculas estavam paralelas à linha mediana e separadas por linhas de aposição óssea. A camada de tecido ósseo maduro (lamelar ou tecido ósseo secundário) era estreita quando comparada à camada de tecido ósseo imaturo (não lamelar ou primário), que estava circundando as bordas laterais da sutura palatina mediana. Além disso, notou-se a presença de numerosos osteócitos no interior de suas lacunas. Os sistemas de Havers caracterizaram-se por estarem organizados e circundados por pequenas cavidades medulares, preenchidas por tecido conjuntivo fibroso. Cada sistema de Havers caracterizou-se por inúmeras lamelas concêntricas, agrupadas ao redor do canal axial estreito, contendo vasos sanguíneos e pequena quantidade de tecido conjuntivo frouxo. Estes achados histológicos foram observados nas avaliações realizadas em grande aumento (Figuras 9A, 9B, 10A, 10B, 11A e 11B, páginas 57, 59, 61).

As principais diferenças observadas no grupo $D$ foi a presença de uma maior faixa de tecido ósseo imaturo e de maior quantidade de áreas de remodelação ativa quando comparado aos grupos C e V (Figuras 9C, 10C e 11C, páginas 57, 59, 61).

\subsubsection{Grupos com disjunção maxilar}

O procedimento de disjunção provocou mudanças expressivas nos componentes das estruturas da sutura palatina mediana, devido à grande intensidade da força (ortopédica) aplicada na região. Ao se aplicar a força sobre a coroa dos incisivos centrais superiores, podese observar a presença de áreas de pressão (faces distais) e de tração (faces mesiais) no ligamento periodontal, que resultou no movimento de inclinação dentária. No interior da sutura palatina mediana, notou-se regiões típicas de força de tração. Microscopicamente, observouse entre os incisivos a presença de um processo inflamatório no interior da gengiva marginal livre, principalmente nos períodos iniciais de aplicação da força ortodôntica. Estes achados foram confirmados durante o exame clínico intra-bucal.

Nos animais submetidos à disjunção ( $C d, V d$ e $D d)$ observaram-se diferenças histológicas nos períodos de avalição. Desta maneira, as descrições histológicas foram apresentadas nos diferentes períodos, além de serem ressaltadas algumas particularidades que estavam presentes apenas no grupo diabético. Estes achados histológicos serão detalhados adiante. 


\subsubsection{Controle e Veículo submetidos à disjunção (Cd e Vd)}

Estes dois grupos foram descritos juntos, uma vez que não houve diferença entre os animais.

\section{a) 3 dias}

Após 3 dias do procedimento de disjunção, pode-se observar o afastamento das margens ósseas suturais das hemi-maxilas. Parte do tecido sutural se manteve aderido às margens ósseas, porém pode-se notar que havia uma parte do tecido sutural rompido e destacado das margens ósseas. Estes fragmentos destacados foram envoltos por diversos neutrófilos (Figura12D, 12E, página 63).

Um pequeno segmento da região anterior da maxila apresentou um tecido sutural aderido e totalmente amorfo (cor roxa devido à autólise das células). As trabéculas ósseas nesta região exibiram lacunas vazias, sem osteócitos, coradas em roxo mostrando novamente a autólise celular ou invasão por neutrófilos. Principalmente no terço anterior e médio da sutura, observaram-se áreas inflamatórias contendo monócitos, neutrófilos e linfócitos. Nesta região, o tecido sutural remanescente estava alterado, apresentando células contraídas, com núcleos irregulares e picnóticos, fibras colágenas desorganizadas e poucos vasos sanguíneos íntegros (Figura 12D, 12E, página 63).

No terço posterior pode-se notar a predominância de diversas áreas hemorrágicas com hemácias e grande quantidade de vasos hiperêmicos. Esta hemorragia era proveniente das cavidades medulares adjacentes ao tecido sutural. Ainda na região posterior, era possível encontrar áreas inflamatórias, porém em menor quantidade, além de se observar um tecido conjuntivo aderido ao tecido ósseo com fibras colágenas em diversos sentidos (Figura 12D, 12E, página 63).

Neste período também notou-se a presença de alguns osteoclastos no interior das cavidades medulares, nas proximidades das margens ósseas e nas bordas suturais. As células do tecido sutural, como os fibroblastos e osteoblastos, apresentavam-se alteradas e com núcleo picnótico (contraídos e achatados). A superfície óssea caracterizou-se pela presença de osteoclastos, em lacunas de Howship, principalmente na região do terço médio da sutura (Figura 12D, 12E, página 63).

\section{b) 7 dias}

No terço anterior e médio do tecido sutural, pode-se observar grande proliferação vascular e a presença de alguns fibroblastos. Nesta área ainda havia polimorfornucleares (neutrófilos) e grande número de mononucleares, o que caracterizava que neste período nos 
dois terços anteriores, ainda havia a presença de um infiltrado inflamatório. Os ossos de sustentação do tecido sutural caracterizavam-se por trabéculas ósseas remanescentes delgadas e circundadas por células inflamatórias (Figura 13D, 13E, página 65).

No terço médio, a superfície óssea próxima à sutura continha células pouco ativas. No lado oposto, em direção às cavidades medulares, havia numerosos osteoclastos, que estavam no interior das lacunas de Howship, dentro das cavidades medulares, o que caracterizava uma intensa reabsorção óssea solapante.

O terço posterior mostrou uma população celular semelhante aos dois terços anteriores, porém em menor quantidade. Por outro lado, os fibroblastos, estavam mais numerosos e apresentavam fibras colágenas em desenvolvimento, além de se observar grande quantidade de vasos sanguíneos. Nesta região, as trabéculas remanescentes estavam levemente mais espessas e com os osteócitos preservados em suas lacunas. A reabsorção óssea foi bem caracterizada quando da visualização das linhas reversas no interior do tecido (Figura 13D, 13E, página 65).

\section{c) 10 dias}

O espaço sutural estava ainda altamente irregular e se mostrava preservado apenas no seu terço posterior. O terço anterior do tecido sutural, caracterizou-se por fibras colágenas desorganizadas não contínuas em sua extensão e a presença de algumas áreas de autólise celular. Na região posterior do tecido sutural, as fibras colágenas mostravam um padrão de orientação mais organizado e com a sua inserção ancorada em tecido ósseo (fibras de Sharpey) (Figura 14D, 14E, página 67).

Neste período, pode-se notar a presença de diversos vasos sanguíneos, fibroblastos, osteoblastos e osteoclastos, indicando um cenário de grande atividade celular, visto que foi observado diversas áreas de remodelação óssea, evidenciadas por áreas erosivas. Nos ossos de sustentação do tecido sutural, as características eram semelhantes ao grupo anterior de 7 dias. Pode-se notar a presença de fragmentos ósseos pequenos com lacunas ocupadas por osteócitos. Nas regiões de neoformação óssea estavam evidentes as linhas reversas. Ao longo da sutura, as células em contato com a superfície óssea próxima à sutura apresentavam-se irregulares e volumosas (Figuras 14D e 14E, página 67).

Portanto, pode-se observar locais com verdadeiro processo de reabsorção óssea, onde se evidenciou a presença de alguns osteoclastos multinucleados ativos justapostos às superfícies, que estavam realizando absorção do tipo frontal. O tecido ósseo que estava sendo reabsorvido, apresentou contorno irregular e com poucas lacunas. Este tecido estava reduzido em seu volume e envolto por um tecido ósseo imaturo. Apesar da formação óssea 
evidente, este tecido neoformado ainda não havia sido suficiente para preencher todo o espaço sutural aberto pela disjunção maxilar (Figuras 14D e 14E, página 67).

\subsubsection{Diabetes submetidos à disjunção (Dd)}

\section{a) 3 dias}

O tecido sutural mostrou-se muito alterado, com mudanças substanciais em seus componentes, devido ao trauma provocado pelo rompimento da sutura palatina mediana associado ao DM. Notou-se um alargamento desse espaço, principalmente na região anterior da sutura. O tecido sutural caracterizou-se por diversas células em degradação, inclusive no interior das cavidades medulares. Principalmente no terço anterior da sutura, as margens ósseas suturais, apresentavam um tecido sutural aderido, porém com regiões onde este tecido estava completamente hialinizado, enquanto em outras, observou-se um tecido semihialinizado. Ainda no terço anterior, este tecido hialinizado caracterizou-se pela presença de fibras colágenas em degradação com ausência de osteoblastos nas margens ósseas suturais (Figura $12 \mathrm{~F}$, página 63).

No terço médio e posterior, parte desse tecido hialinizado caracterizou-se por necrose tecidual. Em algumas regiões havia alguns fibroblastos íntegros, fibras colágenas desorganizadas e presença de estruturas fibrilares. Porém, em outras regiões, estas fibras apresentavam-se com uma direção em sentido sagital.

$\mathrm{Na}$ região central do sutura, no terço anterior, o tecido sutural caracterizou-se por ausência de áreas hemorrágicas, porém com escassos fibroblastos preservados, visto que a maioria destas células já se apresentavam "arroxeadas" e com os seus núcleos picnóticos, isto é, em verdadeiro processo de autólise. Os neutrófilos presentes nesta região estavam mostrando um perfil de processo inflamatório intenso. A intensidade deste tecido inflamatório reduzia conforme se deslocava em direção ao terço médio e posterior da sutura (Figura 12F, página 63).

O tecido vascular no terço anterior, apresentava um aspecto bem alterado com presença de rede de fibrinas. Entretanto, no terço médio e posterior, foi observado vasos sanguíneos hiperêmicos próximos à borda óssea sutural com a presença de áreas hemorrágicas.

Nas bordas suturais não foi observado a presença de macrófagos, porém no interior das cavidades medulares, próximas às bordas suturais havia uma intensa proliferação de osteoclastos e inúmeras lacunas de Howship, caracterizando a reabsorção óssea solapante. Em algumas cavidades medulares foram encontradas diversas células precursores da 
linhagem hematopoiética que estavam destruídas. Porém outras cavidades apresentavam características normais do tecido hematopoiético. Este fenômeno foi mais evidente no terço anterior do que nos terço médio e posterior da sutura (Figura 12F, página 63).

\section{b) 7 dias}

O espaço sutural neste grupo ainda estava amplo comparado ao grupo controle no mesmo período de avaliação. Este período foi caracterizado pela presença de infiltrado inflamatório de polimorfonucleares em toda a extensão do tecido sutural. Algumas células deste tecido apresentavam-se com o núcleo irregular ou picnótico. A superfície óssea sutural ainda estava regular em toda sua extensão. Contudo, no terço anterior da sutura havia algumas lacunas de Howship, que estava caracterizando uma reabsorção óssea direta, porém em menor quantidade ao observado no grupo anterior descrito.

Por outro lado, na porção posterior da sutura, no interior do tecido sutural, observaram-se um processo de vasodilatação e presença de hiperemia em numerosos capilares, principalmente no interior das cavidades medulares próximas às bordas suturais. Estas cavidades medulares caracterizaram por uma intensa reabsorção óssea solapante com a presença de numerosos osteoclastos ativos. Esta reabsorção óssea foi predominante principalmente neste período. As cavidades medulares ainda apresentavam proliferação de vasos sanguíneos, células adiposas e células com núcleos esféricos, isto é, células jovens (precursores). Estas células jovens eram constituídas principalmente de neutrófilos jovens, com núcleos grandes ovóides e claros, entremeando as células esféricas escuras (Figura 13 F, página 65).

\section{c) 10 dias}

$\mathrm{Na}$ região anterior da sutura, o tecido sutural mostrou as mesmas características do período anterior, ou seja, houve predomínio de proliferação de células inflamatórias. Na região posterior o tecido sutural apresentava um processo inflamatório menos intenso e com predomínio de fibroblastos.

No terço anterior da sutura, havia tecido ósseo imaturo, porém em menor quantidade comparado ao grupo controle com disjunção aos 10 dias. Havia a presença de osteoblastos contornando a borda sutural, porém a maioria destas células estavam inativas.

A presença de reabsorção óssea solapante ainda era evidente neste período. As cavidades medulares apresentavam inúmeros osteoclastos multinucleares ativos, com citoplasma abundante, dispostos ao longo da superfície óssea, isolados ou em pequenos grupos. Estas células estavam caracterizando um padrão de intensa atividade de reabsorção 
óssea solapante. Este quadro de reabsorção tornou a superfície óssea da cavidade medular irregular, recortada e com várias lacunas de Howship. Neste contexto, também pode-se observar vasos sanguíneos hiperêmicos e proliferação celular dentro das cavidades medulares (Figura14F, página 67). 
Figura 9 - Região da sutura palatina mediana dos grupos: Controle (A); Veículo (B) e Diabético (C) no período de 3 dias de avaliação. S: Tecido sutural com fibroblastos e fibras colágenas inseridas de uma borda à outra da sutura; OI: Tecido ósseo imaturo com predominância de osteócitos nas cavidades; OM: Tecido ósseo maduro com predominância de linhas concêntricas; VV: Vasos sanguíneos distribuídos pelas fibras colágenas; Seta: osteoblastos inativos recobrindo a superfície óssea. 

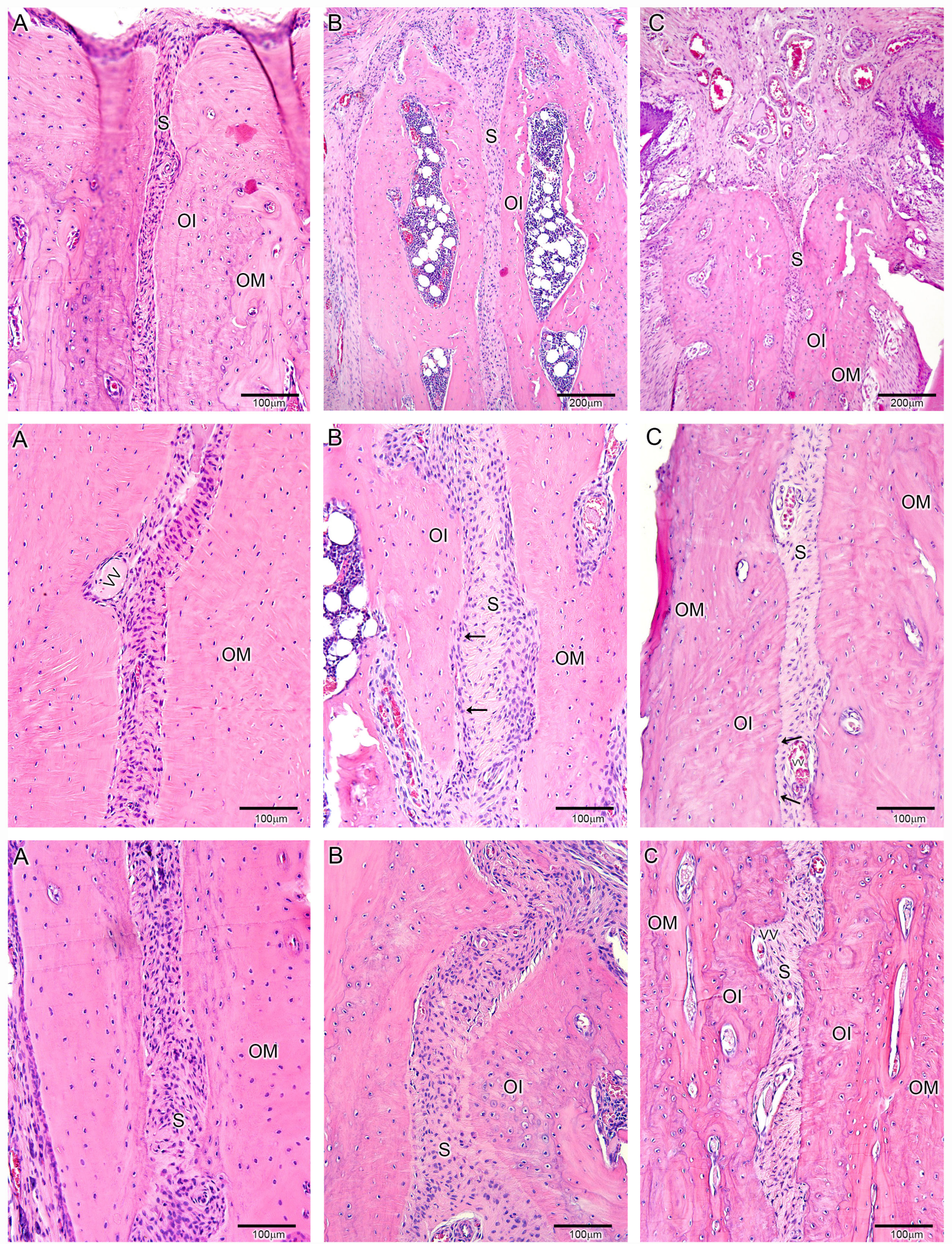
Figura 10 - Região da sutura palatina mediana dos grupos: Controle (A); Veículo (B) e Diabético (C) no período de 7 dias de avaliação. S: Tecido sutural com fibroblastos e fibras colágenas inseridas de uma borda à outra da sutura; OI: Tecido ósseo imaturo com predominância de osteócitos nas cavidades; OM: Tecido ósseo maduro com predominância de linhas concêntricas; VV: Vasos sanguíneos hiperêmicos distribuídos entre fibras colágenas; $\mathbf{C M :}$ Cavidade medular; Seta: osteoblastos inativos recobrindo a superfície óssea. 

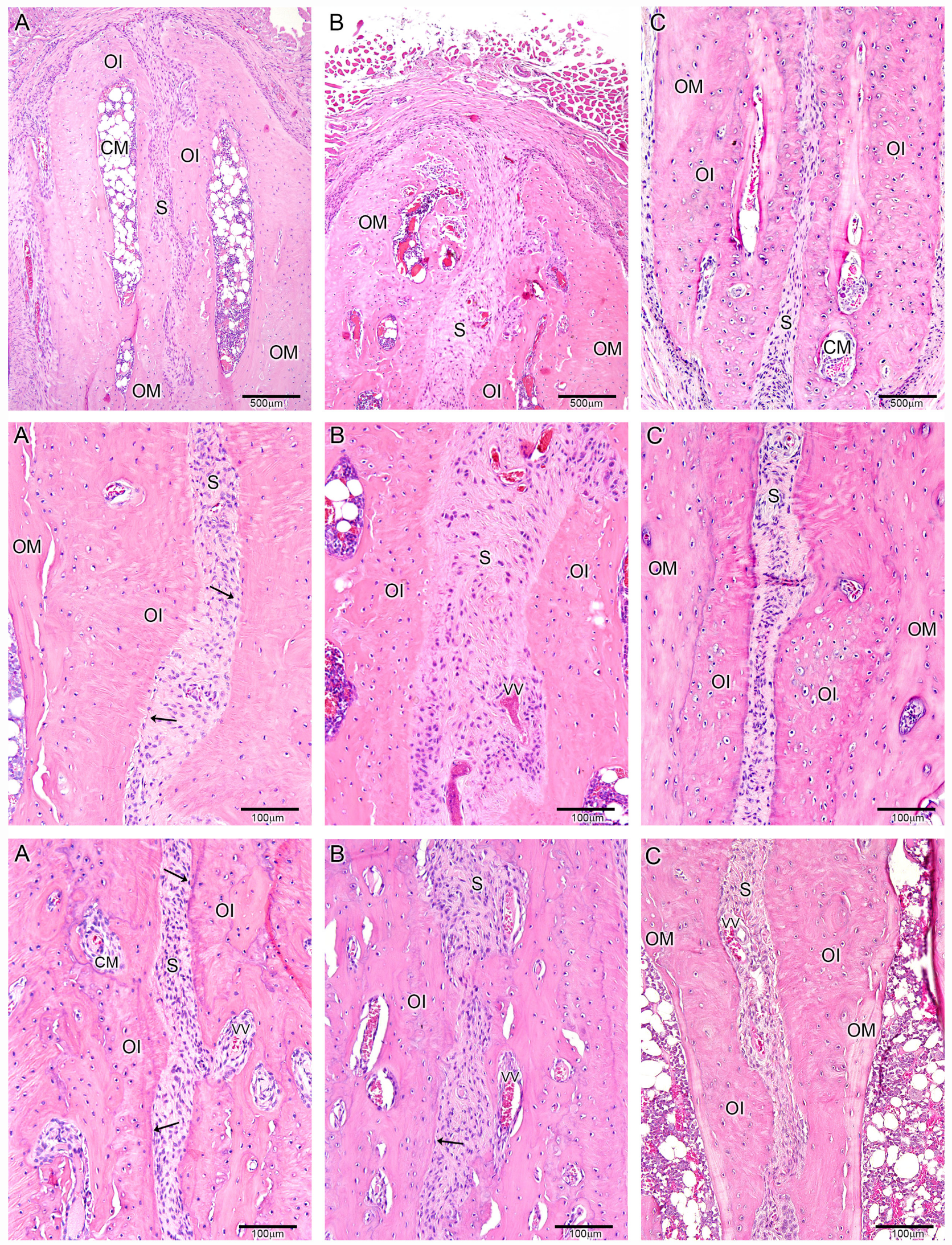
Figura 11 - Região da sutura palatina mediana dos grupos: Controle (A); Veículo (B) e Diabético (C) no período de 10 dias de avaliação. S: Tecido sutural com fibroblastos e fibras colágenas inseridas de uma borda à outra da sutura; OI: Tecido ósseo imaturo com predominância de osteócitos nas cavidades; OM: Tecido ósseo maduro com predominância de linhas concêntricas; VV: Vasos sanguíneos distribuídos entre fibras colágenas; CM: Cavidade medular; Seta preta: osteoblastos inativos recobrindo a superfície óssea. 

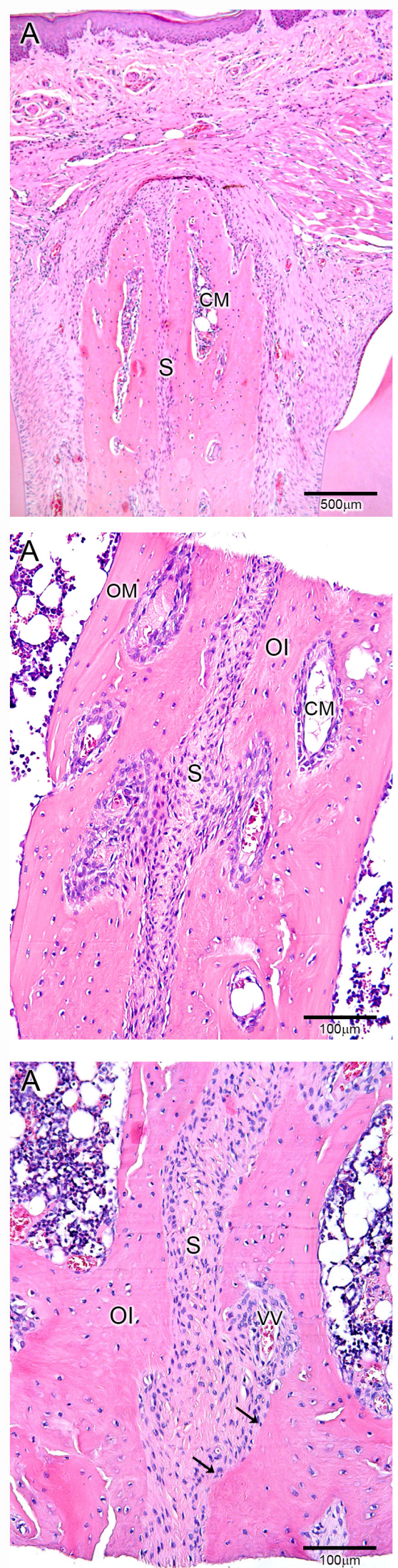
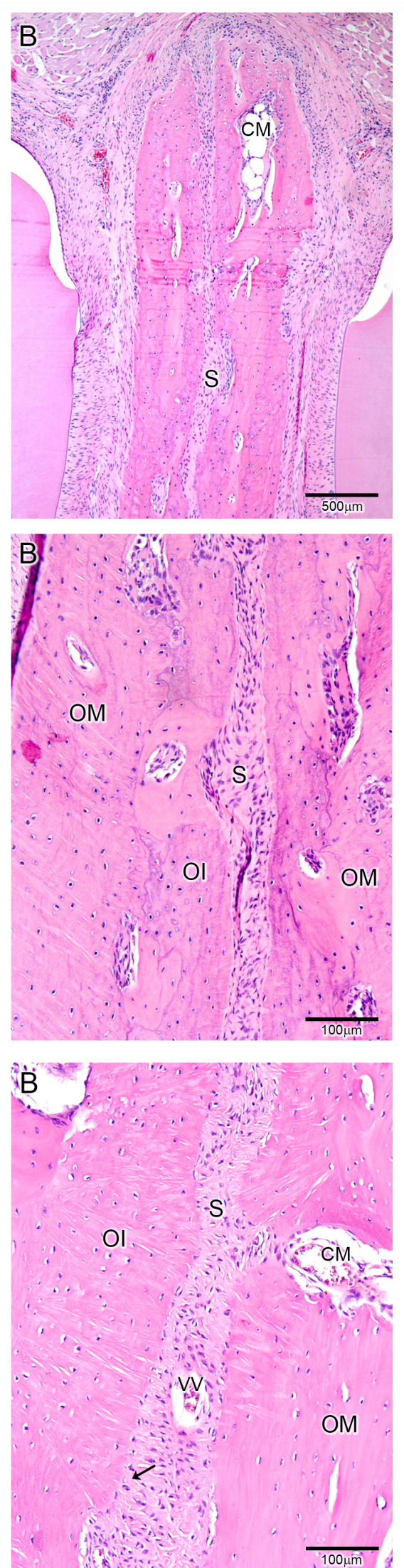
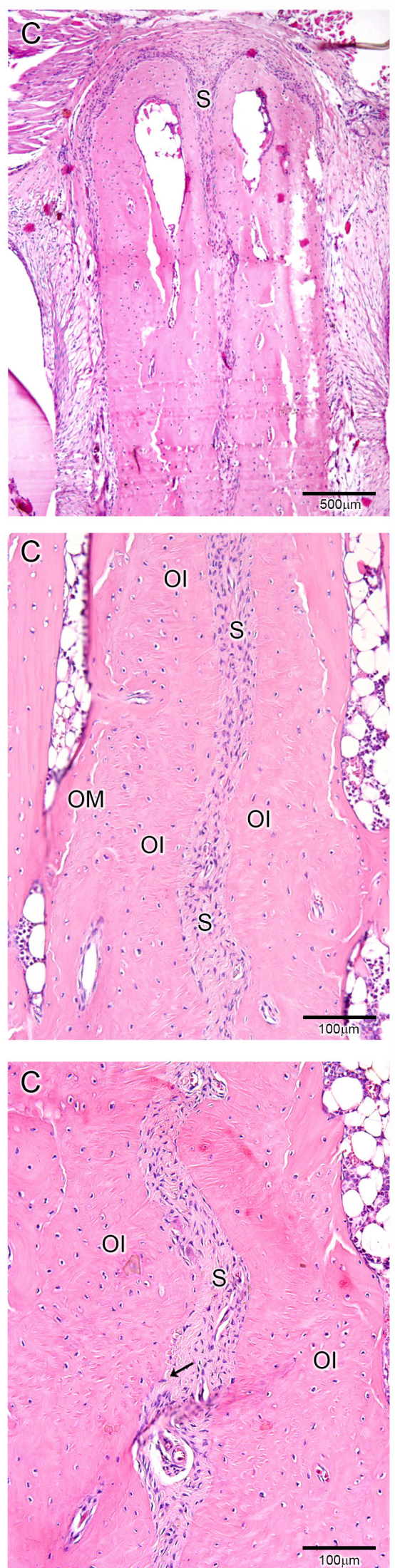
Figura 12 - Região da sutura palatina mediana dos grupos: Controle + Expansão Rápida da maxila (D); Veículo + Expansão rápida da maxila (E) e Diabético + Expansão rápida da maxila $(\mathbf{F})$ no período de 3 dias de avaliação. TC: Tecido conjuntivo contendo células inflamatórias; (h) áreas hemorrágicas; O: Bordas ósseas internas da sutura palatina mediana; IF: infiltrado inflamatório com predominância de células mononucleares; VV: Vasos sanguíneos hiperêmicos; CM: Cavidade medular. 

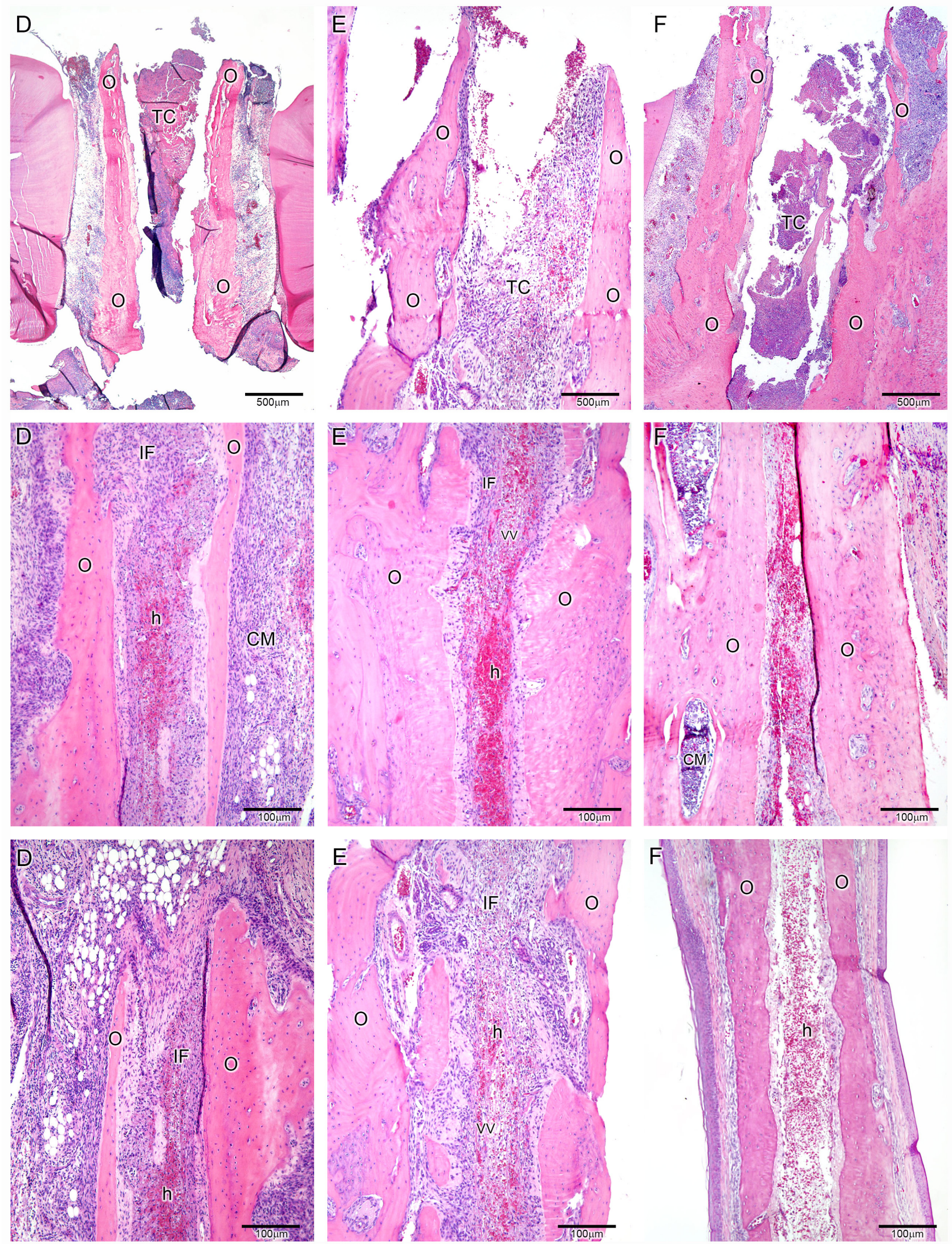
Figura 13 - Região da sutura palatina mediana dos grupos: Controle + Expansão Rápida da maxila (D); Veículo + Expansão rápida da maxila (E) e Diabético + Expansão rápida da maxila (F) no período de 7 dias de avaliação. TC: Tecido conjuntivo contendo células inflamatórias; (h) áreas hemorrágicas; O: Bordas ósseas internas da sutura palatina mediana; OI: Tecido ósseo imaturo com predominância de osteócitos nas cavidades; OM: Tecido ósseo maduro com predominância de linhas concêntricas; VV: Vasos sanguíneos hiperêmicos com a presença de algumas áreas hemorrágicas (h); CM: Cavidade medular; Seta: osteoclastos ativos reabsorvendo a superfície óssea. 

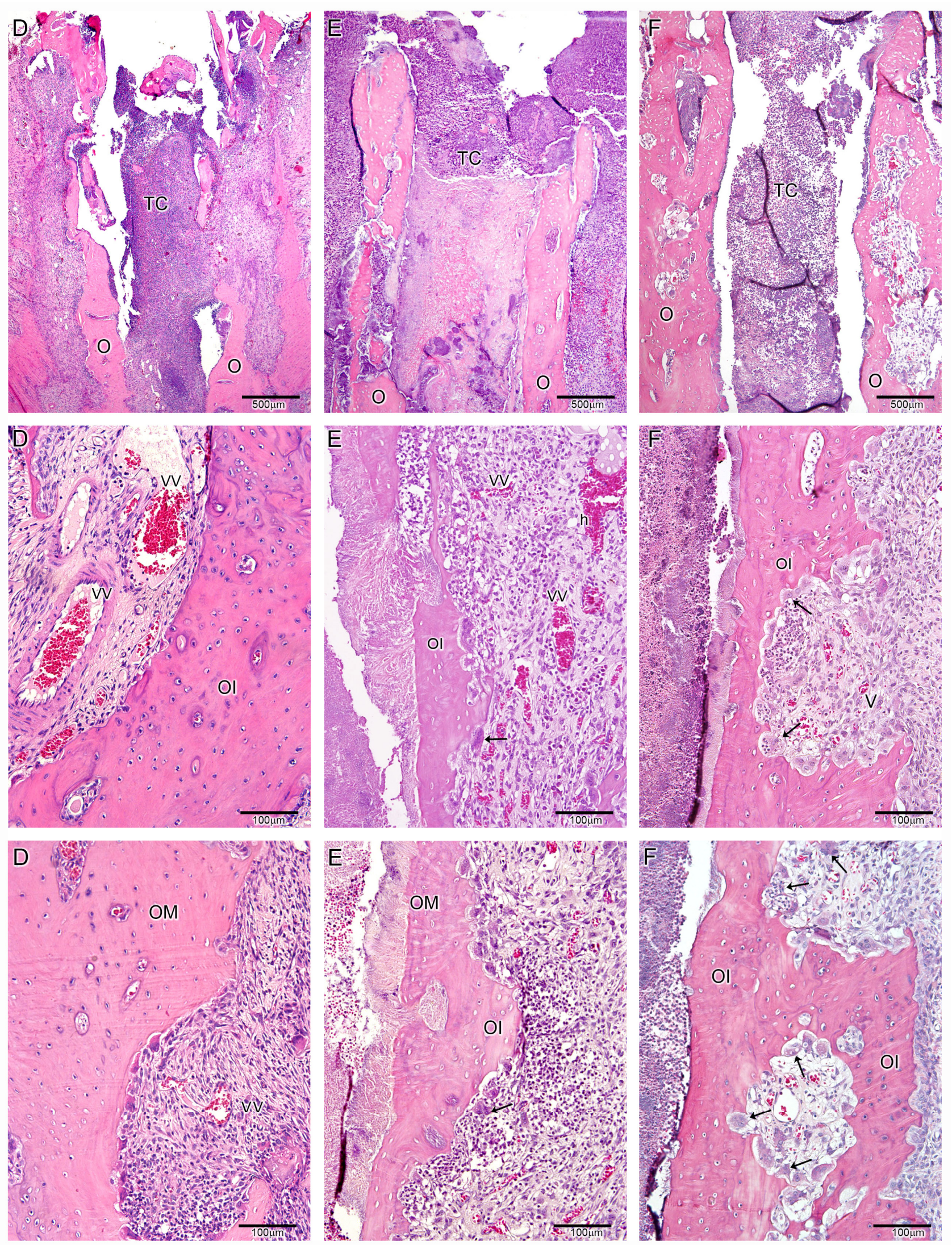
Figura 14 - Região da sutura palatina mediana dos grupos: Controle + Expansão Rápida da maxila (D); Veículo + Expansão rápida da maxila $(E)$ e Diabético + Expansão rápida da maxila (F) no período de 10 dias de avaliação. TCI: Tecido conjuntivo ainda contendo células inflamatórias mononucleares; TC: Tecido conjuntivo com proliferação de células fibroblásticas; O: Bordas ósseas internas da sutura palatina mediana; OI: Tecido ósseo imaturo com predominância de osteócitos nas cavidades; OM: Tecido ósseo maduro com predominância de linhas concêntricas; VV: Vasos sanguíneos hiperêmicos; CM: Cavidade medular; Seta: osteoclastos ativos localizados no interior das cavidades de Howship. 

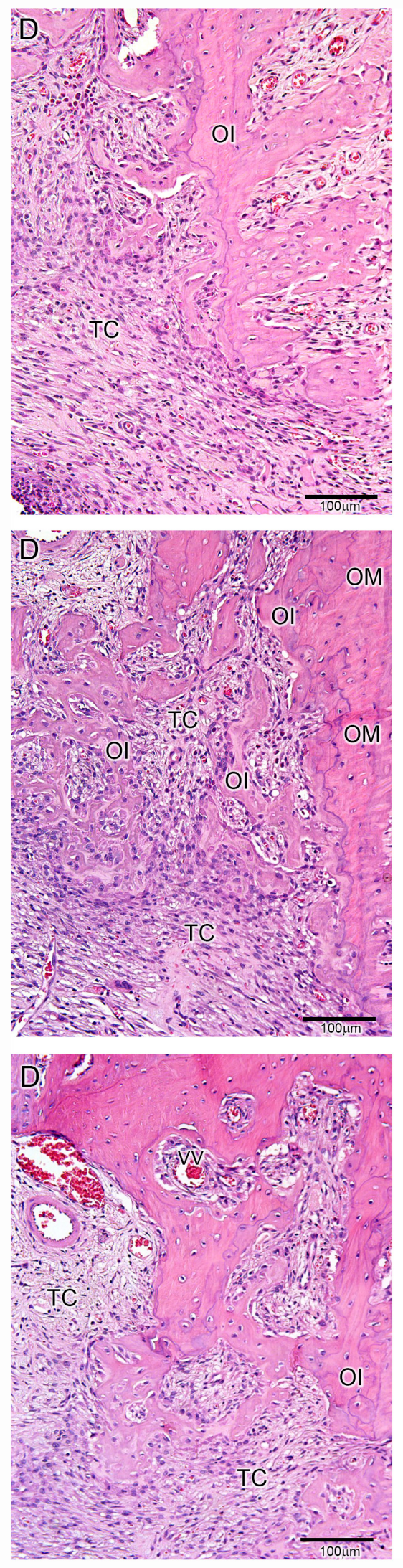
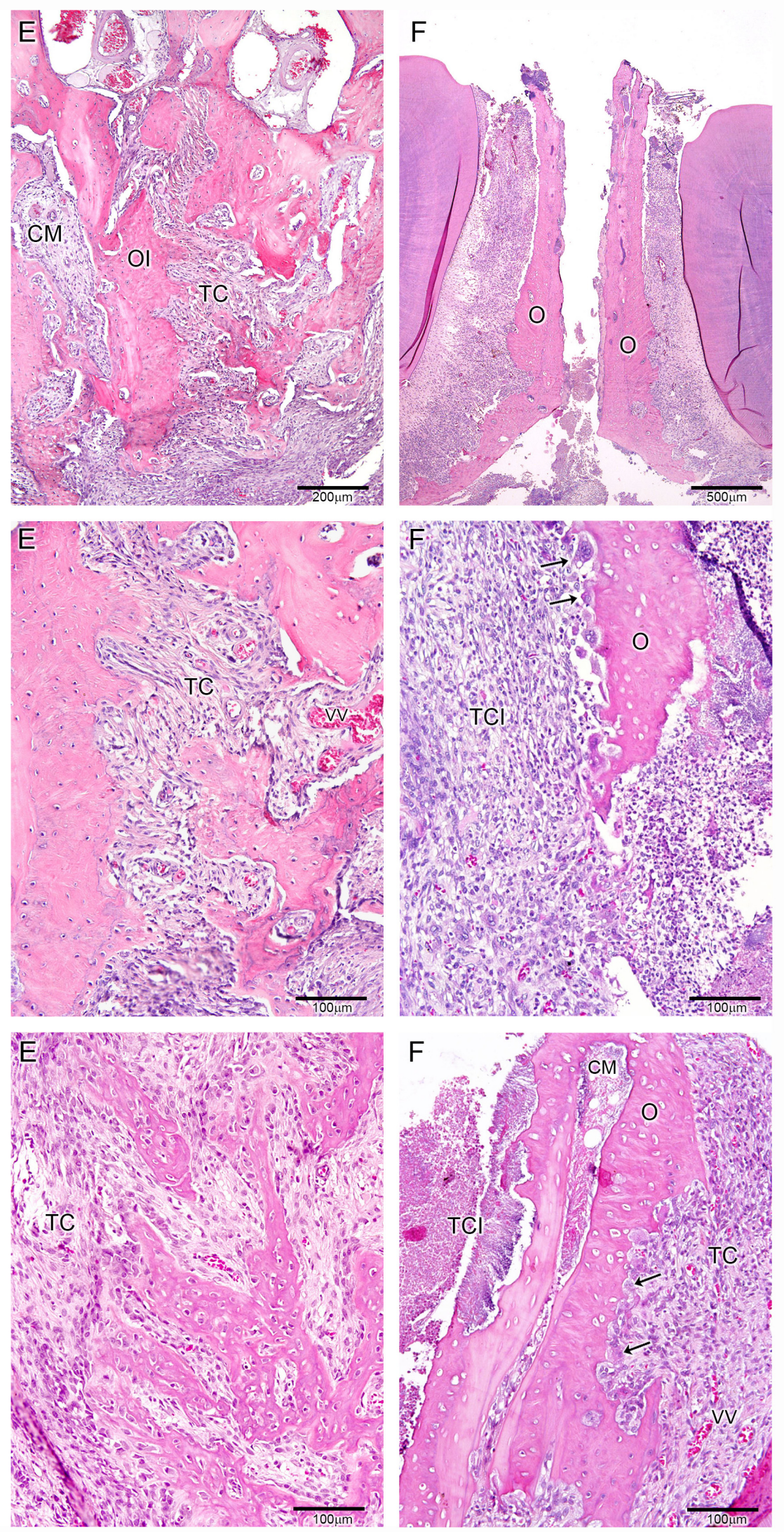


\section{4 qRT-PCR E WESTERN BLOTTING}

Observou-se diferença estatisticamente significante em relação ao tempo e tratamento quando foi analisada a expressão relativa dos RNAm dos genes Bmp2 (Bmp2), Ibsp (Bsp), Spp1 (Opn), Sparc (Onc), Bglap (Occ), Tnfrsf11a (Rank), Tnfsf11 (Rankl) e Tnfrsf11b (Opg) $(p<0,05)$, assim como da expressão proteica de BMP2, BSP, OPN, OCC, RANKL e OPG, durante os diferentes tempos e grupos (tratamento) de avaliação $(p<0,05)$. Entretanto não se observou diferença estatística na expressão proteica de ONC e RANK quando se analisou os diferentes grupos para cada tempo de avaliação $(p>0,05)$, apenas foi encontrada diferença quando avaliou-se os diferentes tempos para cada grupo de estudo $(p<0,05)$.

Abaixo foi descrito minuciosamente os resultados para cada gene e proteína de interesse envolvidos no processo de remodelação óssea.

\section{a) Expressão de RNAm de Bmp2 e expressão proteica de BMP2}

$\mathrm{Na}$ análise da expressão gênica nos diferentes grupos de estudo, notou-se que no período de três dias, não houve diferença estatística na expressão do gene Bmp2 entre os diferentes tratamentos $(p>0,05)$. No período de 7 dias, houve uma redução na expressão relativa do RNAm do gene $B m p 2$ no grupo $D$ comparado aos grupo $C(p<0,05)$. No período de 10 dias, observou-se diferença estatisticamente significante quando se comparou o grupo C com o grupo D e Cd, ou seja, estes grupos apresentaram uma redução da expressão de Bmp2 comparado ao grupo C $(p<0,05)$. Por outro lado, o grupo Dd apresentou um estímulo na expressão de Bmp2 quando comparado aos grupos D e Cd $(p<0,05)$ (Figura 15A).

Ao se analisar os tempos de estudos, pode-se observar que houve uma maior expressão de $B m p 2$ no grupo $D$ aos 3 dias comparado ao tempo de 7 dias $(p<0,05)$ e um padrão similar foi observado no grupo $D$ aos 7 dias comparado aos 10 dias $(p<0,05)$. $O$ pico de maior expressão de Bmp2 do grupo Dd foi aos 10 dias, seguido do período de 3 dias quando comparados ao período de 7 dias (Figura 15B).

Avaliando-se a expressão proteica de BMP2 nos diferentes grupos de estudos, podese observar que no tempo de 3 dias houve maior expressão proteica no grupo $C$ comparado ao grupo $\mathrm{Cd}(p<0,05)$, assim como no grupo D comparado ao grupo $\mathrm{C}(p<0,05)$ e $\mathrm{Dd}(p<0,05)$. Aos 7 dias observou-se padrão similar de expressão ao que foi encontrado aos 3 dias, além de maior expressão no grupo Dd comparado ao grupo $\mathrm{Cd}(p<0,05)$. Aos 10 dias o padrão de expressão encontrado aos 3 dias novamente se repetiu (Figura 15C). 
Ao se analisar os tempos de estudos, pode-se observar que houve um estímulo na expressão de BMP2 no grupo $\mathrm{C}$ ao 7 dias comparado ao 3 dias e um resultado inverso aos 10 dias comparado aos 7 dias $(p<0,05)$. Além disso, houve uma maior expressão no grupo $C$ aos 3 dias comparado ao grupo $\mathrm{C}$ aos 10 dias de avaliação. Padrão similar de expressão de BMP2 no grupo $C$ também foi encontrado no grupo $D$, exceto aos 10 dias que no grupo $D$ observou-se maior expressão de BMP2 comparado aos 3 dias $(p<0,05)$. Para o grupo Cd e Dd houve um estímulo na expressão de BMP2 aos 7 dias comparado aos tempos de 3 $(p<0,05)$ e 10 dias $(p<0,05)$ (Figura 15D).

A

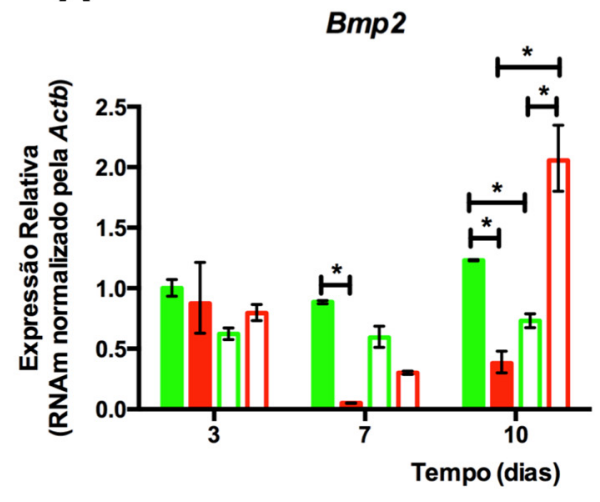

C

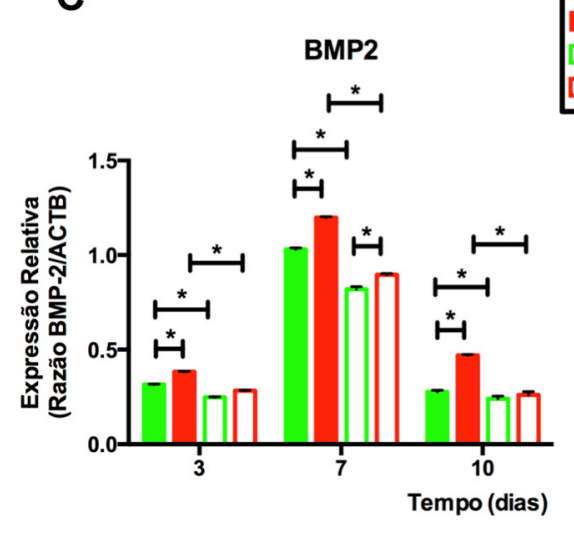

B
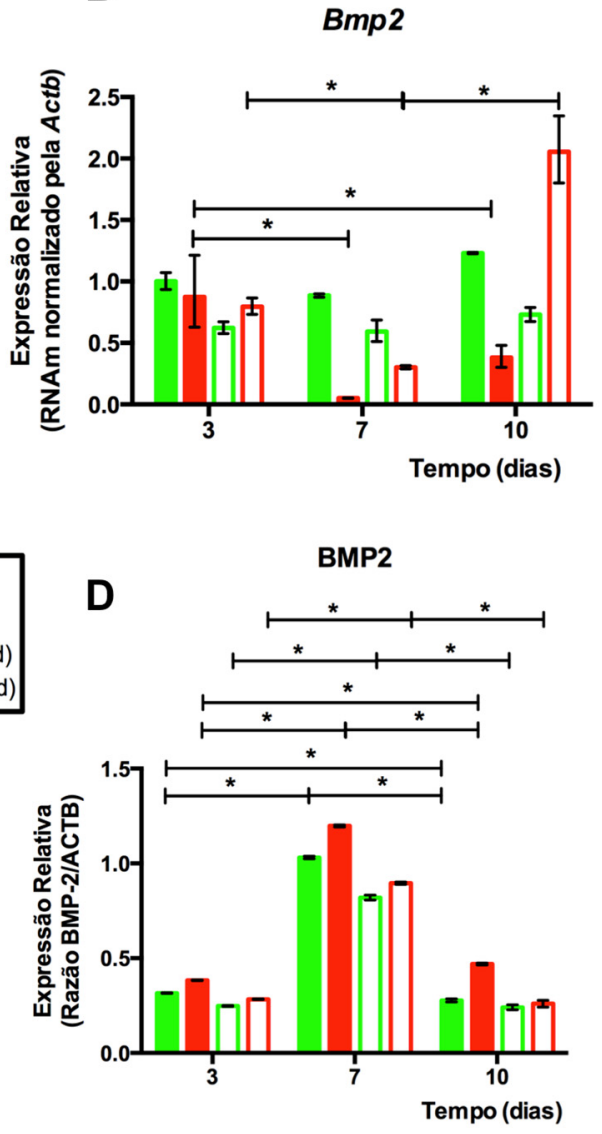

Figura 15: (A) Expressão do RNAm do gene Bmp2 nos diferentes grupos e (B) tempos de avaliação. (C) Expressão proteica de BMP2 nos diferentes grupos e (D) tempos de avaliação. Os gráficos mostram a média, desvio padrão e * $p<0,05$.

\section{b) Expressão de RNAm de lbsp (Bsp) e expressão proteica de BSP}

$\mathrm{Na}$ análise da expressão gênica, o grupo $\mathrm{D}$ apresentou estímulo na expressão de mRNA para o gene Ibsp (Bsp) quando comparado ao grupo $\mathrm{C}$ e $\mathrm{Dd}(p<0,05)$ no período de 3 dias. No período de 7 dias, observou-se um estímulo da expressão gênica no grupo $\mathrm{Dd}$ 
comparado aos grupos D e Cd $(p<0.05)$. No período de 10 dias, houve um estímulo na expressão gênica de Ibsp no grupo D comparado ao grupo $\mathrm{Dd}(p<0,05)$ (Figura 16A).

Ao se analisar os tempos de estudo, pode-se observar um estímulo na expressão de Ibsp no grupo $D$ aos 3 dias quando comparado aos 7 dias $(p<0,05)$, assim como um estímulo da expressão de Ibsp no grupo Dd aos 7 dias comparado aos 3 e 10 dias $(p<0,05)$ (Figura 16B).

$\mathrm{Na}$ análise proteica avaliando-se os diferentes grupos em cada tempo, pode-se notar aos 7 dias, a inibição da expressão de BSP no grupo Dd comparado ao grupo $\mathrm{Cd}(p<0,05)$. Aos 10 dias, observou-se o estímulo deste gene nos grupos $\mathrm{D}$ e Dd comparado ao grupo $\mathrm{C} \mathrm{e}$ Cd respectivamente $(p<0,05)$ (Figura 16C). Considerando o tempo para o diferentes grupos, pode-se observar que o grupo $\mathrm{C}$ apresentou uma maior expressão de BSP aos 7 dias comparados aos 3 e 10 dias de avaliação $(p<0,05)$, assim como houve uma maior expressão de BSP aos 3 dias comparado aos 10 dias $(p<0,05)$. Para o grupo $\mathrm{D}$, houve estímulo da expressão de BSP aos 3 dias comparado aos 10 dias $(p<0,05)$, assim como um estímulo aos 7 dias comparado aos 10 dias $(p<0,05)$. O mesmo padrão e expressão de BSP econtrado no grupo $D$ foi encontrado no grupo $\mathrm{Cd}(p<0,05)$. O grupo $\mathrm{Dd}$ mostrou um redução da sua expressão de BSP aos 10 dias comparado ao tempo de 7dias $(p<0,05)$ (Figura 16D).

A
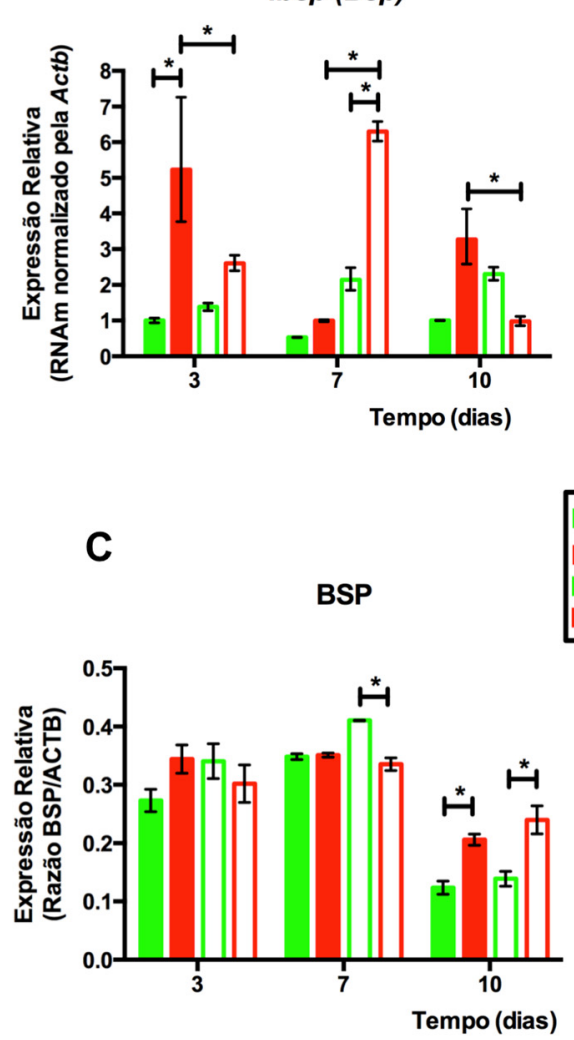

B

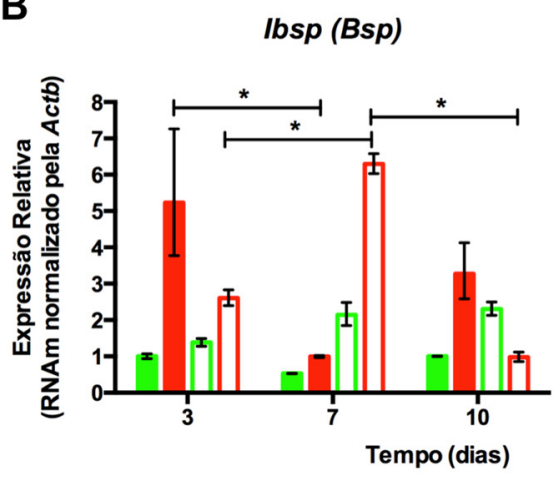

D

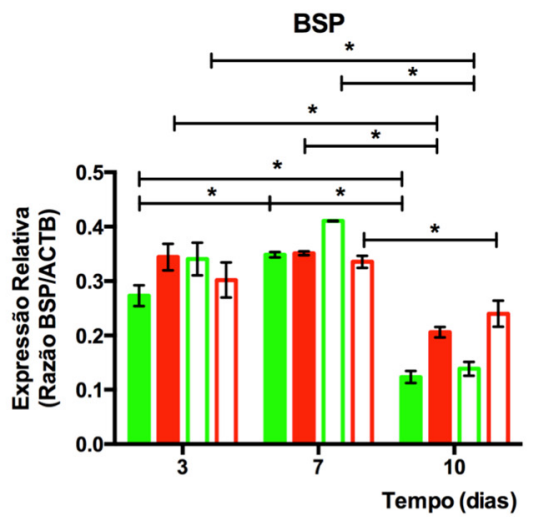

Figura 16: (A) Expressão do RNAm do gene lbsp nos diferentes grupos e (B) tempos de avaliação. (C) Expressão proteica de BSP nos diferentes grupos e (D) tempos de avaliação. Os gráficos mostram a média, desvio padrão e * $p<0,05$. 


\section{c) Expressão de RNAm de Spp1 (Opn) e expressão proteica de OPN}

Ao se analisar os diferentes grupos em cada tempo, pode-se notar que no período de 3 dias, o grupo D apresentou um estímulo para a expressão de RNAm para o gene Spp1 (Opn) quando comparado ao grupos $\mathrm{C}(p<0,05)$, assim como o grupo Dd apresentou um estímulo para o gene de interesse quando comparado ao grupo $\mathrm{Cd}(p<0,05)$. No período de 7 dias pode-se observar um estímulo na expressão gênica no grupo $\mathrm{Cd}$ comparado ao grupo C e Dd $(p<0,05)$. Avaliando-se o período de 10 dias, observou-se um estímulo da expressão do gene de interesse no grupo Cd comparado ao grupo $C(p<0,05)$ (Figura 17A). Na análise do tempo, pode-se observar que o grupo $D$ teve um estímulo na expressão gênica de Opn aos 3 dias comparado ao tempo de 7 dias $(p<0,05)$. Houve uma inibição da expressão do gene de interesse no grupo Cd aos 3 dias comparado aos tempos de 7 e 10 dias de avaliação $(p<0,05)$. Para o grupo Dd houve uma maior expressão gênica aos 10 dias do que aos 7 dias $(p<0,05)$ (figura 17B).

$\mathrm{Na}$ análise proteica, observou-se estímulo da expressão de BSP no grupo C comparado ao grupo $D$ aos 3 dias de avaliação $(p<0,05)$ (Figura $17 \mathrm{C})$. Ao analisar o tempo nos diferentes grupos, pode notar o estímulo deste gene no grupo $\mathrm{C}$ aos 3 dias comparado aos 7 e 10 dias de avaliação $(p<0,05)$. O padrão de expressão encontrado no grupo $C$ também foi observado no grupo $\mathrm{Cd}(p<0,05)$. Para o grupo Dd houve maior expressão aos 3 dias quando comparado com o tempo de 10 dias $(p<0,05)$ (Figura 17D).

A
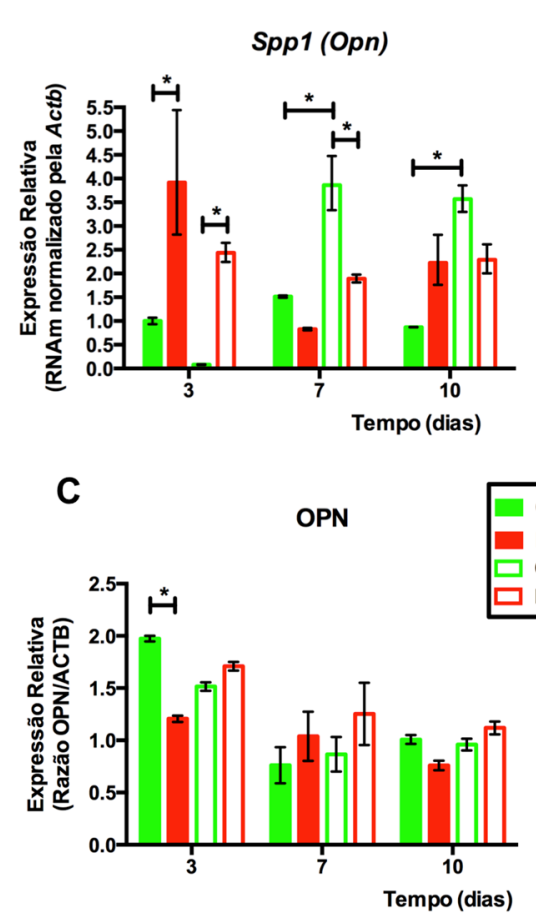

B
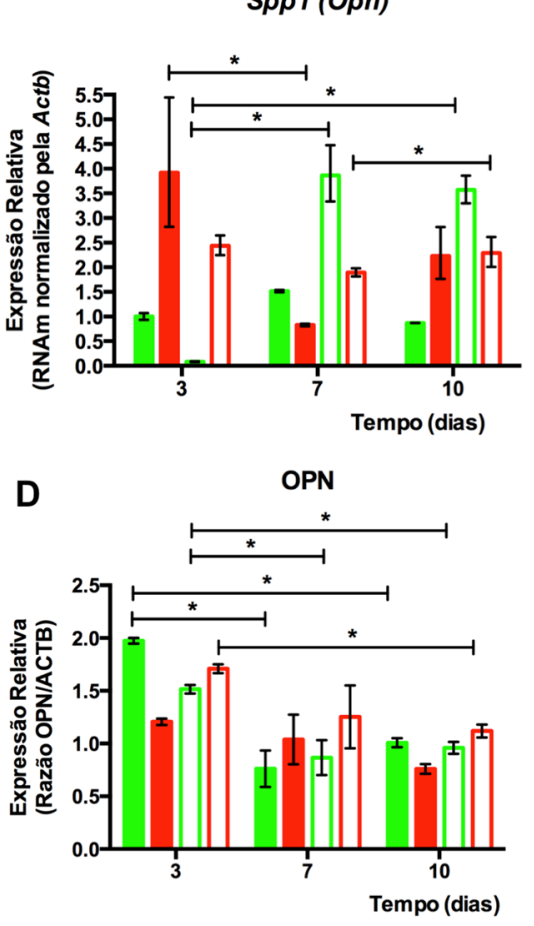

Figura 17: (A) Expressão do RNAm do gene Opn nos diferentes grupos e (B) tempos de avaliação. (C) Expressão proteica de OPN nos diferentes grupos e (D) tempos de avaliação. Os gráficos mostram a média, desvio padrão e * $p<0,05$. 


\section{d) Expressão de RNAm de Sparc (Onc) e expressão proteica de ONC}

$\mathrm{Na}$ análise gênica no período de 3 dias de remodelação óssea, o grupo $\mathrm{D}$ apresentou maior expressão de mRNA para o gene Sparc (Onc) quando comparado ao $C(p<0,05)$, assim como o grupo Dd apresentou um estímulo gênico comparado ao grupo $\mathrm{Cd}(p<0,05)$. No período de 7 dias observou-se padrão inverso do período de 3 dias em relação à expressão gênica dos grupos $\mathrm{Dd}(p<0,05)$, isto é houve uma menor expressão relativa do gene de interesse no grupo Dd comparado ao grupo $\mathrm{Cd}(p<0,05)$. Avaliando-se o período mais tardio do processo de remodelação óssea, pode-se observar que houve uma maior expressão do gene de interesse no grupo $C d$ comparado ao grupo $C(p<0,05)$ (Figura 18A). Ainda na análise gênica, quando avaliou-se o tempo, pode-se observar que o grupo $D$ apresentou estímulo do gene de interesse aos 3 dias quando comparado ao tempo de 7 e 10 dias de avaliação $(p<0,05)$. Por outro lado, o grupo Cd apresentou uma inibição gênica no tempo de 3 dias comparado aos tempos de 7 e 10 dias $(p<0,05)$. O grupo Dd mostrou uma expressão gênica aumentada no tempo de 10 dias comparado ao tempo de 7 dias $(p<0,05)$ (figura 18B).

$\mathrm{Na}$ análise proteica da ONC, não se observou diferença entre os grupos para cada tempo de avaliação $(p>0,05)$ (Figura 18C) . Porém, quando se observou o tempo para cada grupo separadamente, pode-se notar que houve um estímulo na expressão de ONC no grupo C aos 3 e 7 dias comparado ao tempo de 10 dias $(p<0,05)$. Este mesmo padrão de estímulo da expressão de ONC foi observado para os grupos D, Cd e Dd $(p<0,05)$ (Figura 18D) 
A

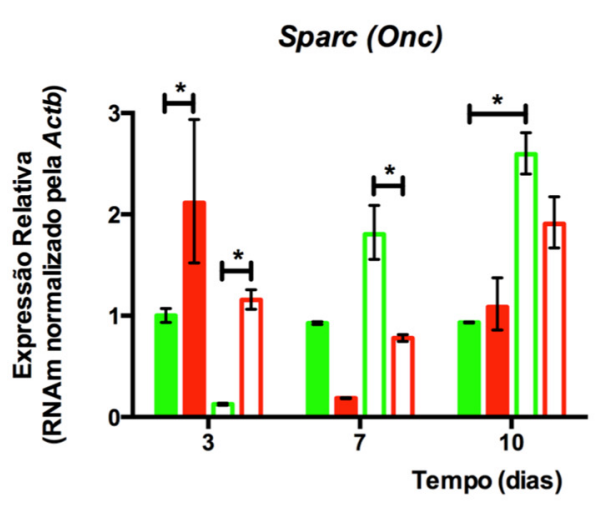

C

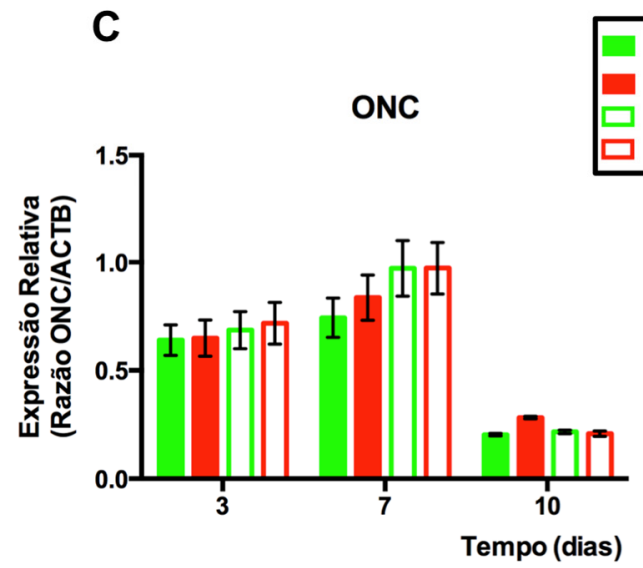

B
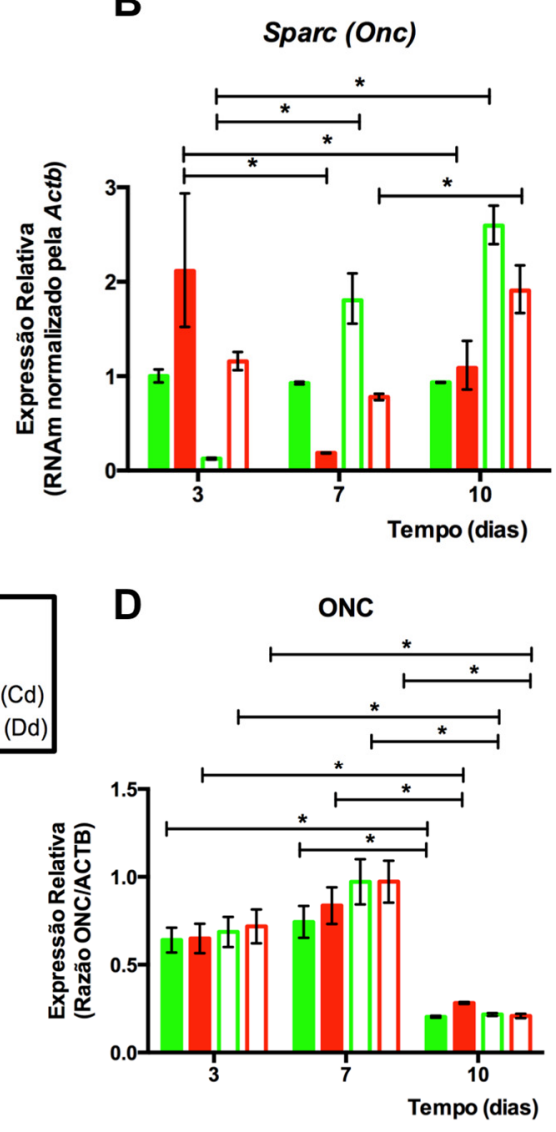

Figura 18: (A) Expressão do RNAm do gene Onc nos diferentes grupos e (B) tempos de avaliação. (C) Expressão proteica de ONC nos diferentes grupos e (D) tempos de avaliação. Os gráficos mostram média, desvio padrão e * $p<0,05$.

\section{e) Expressão de RNAm de Bglap (Occ) e expressão proteica de OCC}

$\mathrm{Na}$ análise gênica, no período de 3 dias o grupo $\mathrm{D}$ apresentou a maior expressão de mRNA para o gene Bglap (Occ) quando comparado aos grupos C e Dd $(p<0,05)$. Avaliandose o período de 7 dias, observou-se uma menor expressão do gene de interesse no grupo $D$ comparando-se ao grupo $C(p<0,05)$. Aos 10 dias de avaliação, observou-se um estímulo na expressão do gene de interesse no grupo Cd comparado ao grupo $C(p<0,05)$ (Figura 19A). Ao se avaliar o tempo na análise gênica para cada grupo, observou-se que o grupo $D$ apresentou uma inibição gênica para Occ aos 7 dias comparado aos 3 dias e 10 dias $(p<0,05)$. O grupo Cd mostrou um estímulo para o gene de intresse aos 10 dias comparado aos tempo de 3 e 7 dias $(p<0,05)$. O grupo Dd apresentou maior expressão gênica no tempo de 10 dias comparado ao tempo de 7 dias ( $p<0,05)$ (Figura 19B).

$\mathrm{Na}$ avaliação proteica, pode-se notar que somente houve diferença estatística entre os grupos no tempo de 3 dias, isto é, aos 3 dias o grupo Dd apresentou maior estímulo de expressão proteica de OCC comparada ao grupo $D(p<0,05)$ (Figura 19C). Ao avaliar-se os 
tempos para cada grupo, observou-se diferença estatística nos grupos Cd e D. O grupo Cd apresentou maior expressão proteica de OCC aos 3dias comparado ao tempo de 10 dias $(p<0,05)$. O grupo Dd mostrou um maior estímulo proteico de OCC aos 3 e 7 dias quando comparado ao tempo de 10 dias $(p<0,05)$ (Figura 19D).

A

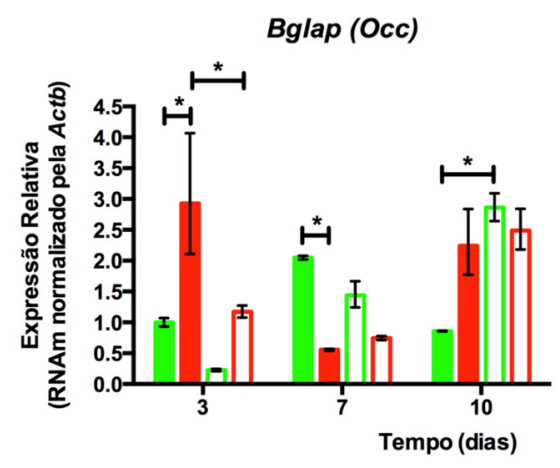

C

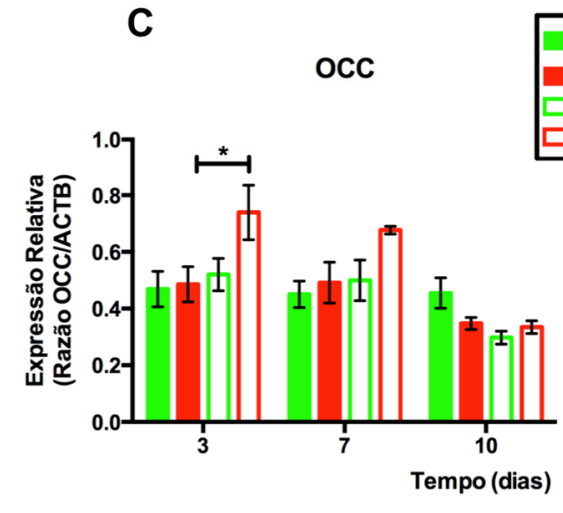

B

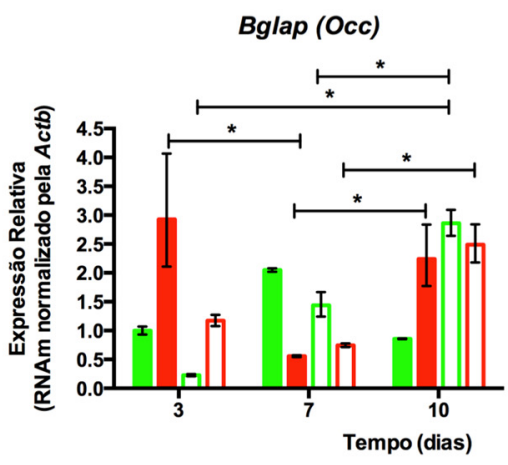

D

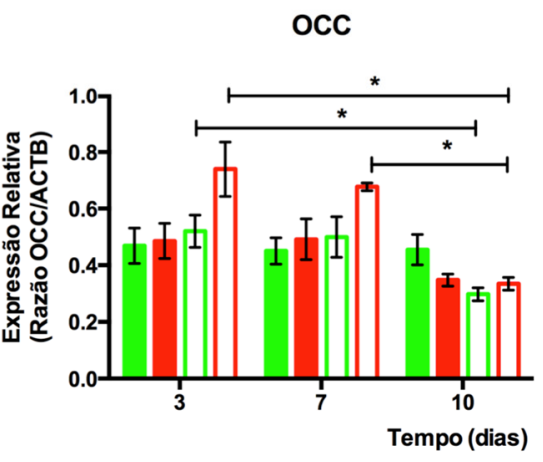

Figura 19: (A) Expressão do RNAm do gene Occ nos diferentes grupos e (B) tempos de avaliação. (C) Expressão proteica de OCC nos diferentes grupos e (D) tempos de avaliação. Os gráficos mostram média, desvio padrão e * $p<0,05$.

\section{f) Expressão de RNAm de Tnfrsf11a (Rank) e expressão proteica de RANK}

No período de 3 dias o grupo $D$ apresentou maior expressão de mRNA para o gene Tnfrsf11a (Rank) quando comparado ao grupo C e Dd $(p<0,05)$. Nos demais tempos não houve diferença entre os diferentes grupos $(p>0,05)$ (Figura 20A). Ao se avaliar o tempo para os diferentes grupos, observou-se para o grupo $D$ maior expressão gênica aos 3 dias comparado aos tempos de 7 e 10 dias $(p<0,05)$. Para o grupo Dd, notou-se uma maior expressão aos 10 dias comparado ao tempo de 7 dias $(p<0,05)$ (Figura 20B).

$\mathrm{Na}$ análise proteica não houve diferença estatística entre os diferentes grupos em cada tempo de avaliação $(p>0,05)$ (Figura 20C). Por outro lado, pode-se observar diferença 
estatística em cada grupo nos diferentes tempos de avaliação. No grupo C observou-se uma menor expressão proteica de RANK aos 3 dias comparado ao tempo de 7 e 10 dias $(p<0,05)$. Para o grupo $D$, houve um estímulo na expressão de RANK aos 7 dias comparado aos tempos de 3 e 10 dias $(p<0,05)$, além de se observar que aos 10 dias também houve uma maior expressão proteica comparada aos 3 dias de avaliação $(p<0,05)$. Os grupos Cd e Dd apresentaram padrão de expressão proteica de RANK semelhantes. Observou-se uma inibição da expressão da proteína de interesse nos grupos $\mathrm{Cd}$ e Dd aos 3 dias comparado ao tempo de 7 e 10 dias de avaliação $(p<0,05)$ (Figura 20D).

A

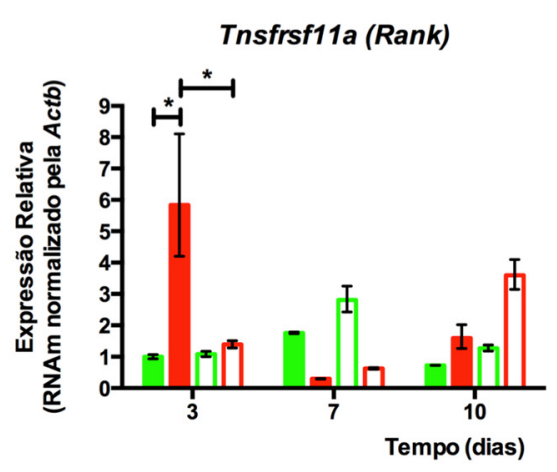

C

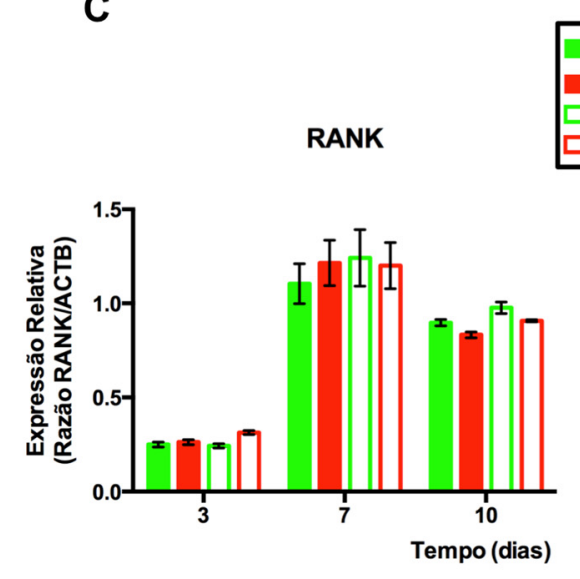

B

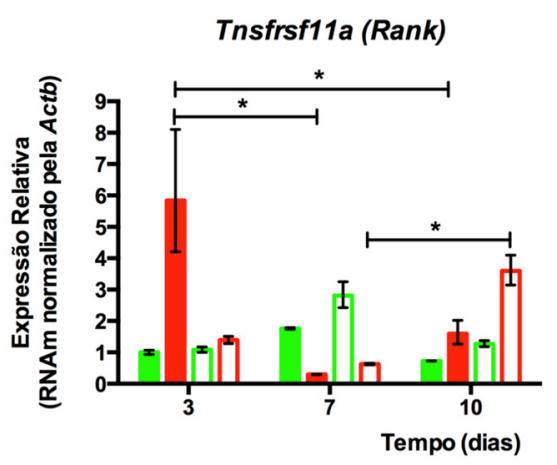

D

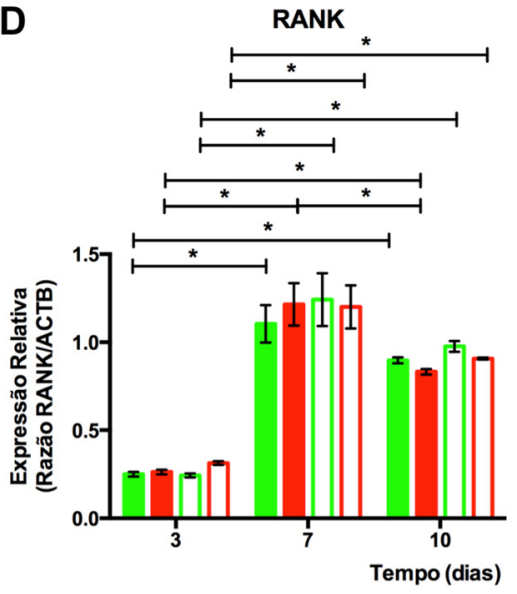

Figura 20: (A) Expressão do RNAm do gene Rank nos diferentes grupos e (B) tempos de avaliação. (C) Expressão proteica de RANK nos diferentes grupos e (D) tempos de avaliação. Os gráficos mostram média, desvio padrão e * $p<0,05$.

\section{g) Expressão de RNAm de Tnfsf11 (Rankl) e expressão proteica de RANKL}

$\mathrm{Na}$ análise gênica, o grupo Dd apresentou maior expressão de mRNA para o gene Tnfsf11 (Rankl) quando comparado ao grupo D e Cd no período de 3 dias $(p<0,05)$. No período de 7 dias, o grupo Dd e Cd apresentaram maior expressão gênica que os grupo D e 
C respectivamente $(p<0,05)$. Ao avaliar o período de 10 dias, observou-se que o grupo $\mathrm{Dd}$ apresentou maior expressão gênica quando comparado aos grupos D e Cd, $(p<0,05)$ (Figura 21A). Ao se avaliar o tempo para os diferentes grupos, observou-se para o grupo Cd maior expressão gênica aos 7 dias comparado ao tempo de 3 dias $(p<0,05)$. Para o grupo Dd, notouse uma maior expressão aos 10 dias comparado ao tempo de 7 dias $(p<0,05)$ (Figura 21B). Para a avaliação proteica, pode-se observar que no tempo de 3 dias o grupo $C$ apresentou um estímulo na expressão de RANKL comparado ao grupo $\mathrm{Cd}(p<0,05)$. Aos 7 dias, houve um maior estímulo da expressão da proteína de interesse no grupo $D$ comparado aos grupos $C$ e Dd $(p<0,05)$. Aos 10 dias o pradão de expressão proteico no grupo $C$ foi semelhante ao encontrado no tempo de 3 dias $(p<0,05)$ (Figura 21C). Ao se avaliar o tempo para os diferentes grupos, pode-se observar que todos os grupos apresentaram estímulo aos 7 dias comparado aos demais tempos $(p<0,05)$, além de se observar que o tempo de 10 dias apresentou inibição da expressão proteica de RANKL comparado ao tempo de 3 dias de avaliação $(p<0,05)$ (Figura 21D).

A

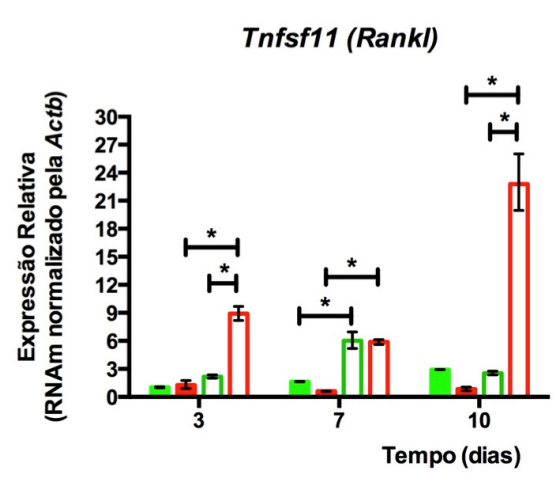

C

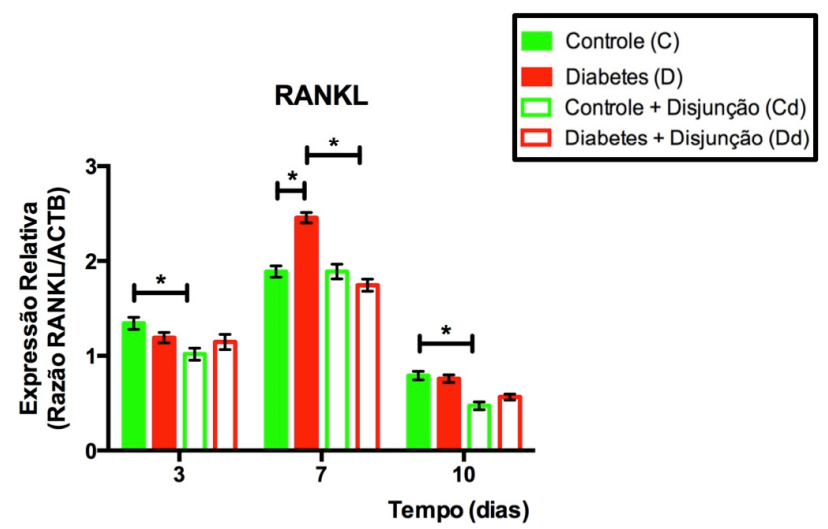

B

Tnfsf11 (Rankl)

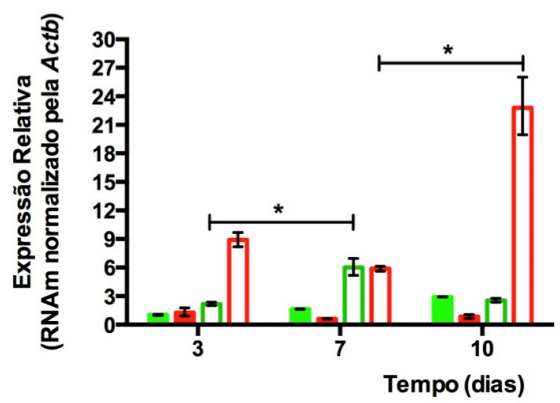

D

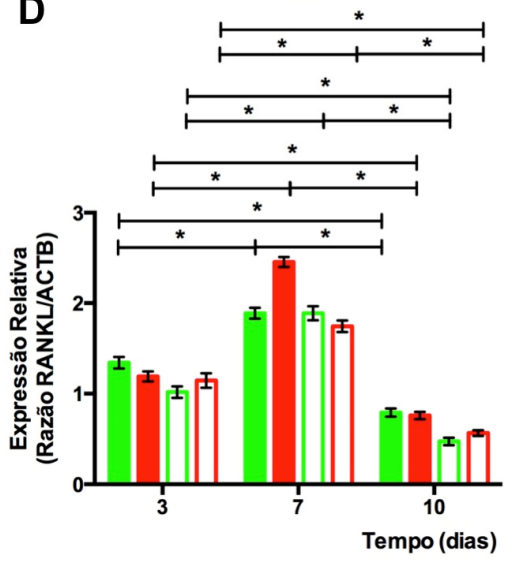

Figura 21: (A) Expressão do RNAm do gene Rankl nos diferentes grupos e (B) tempos de avaliação. (C) Expressão proteica de RANKL nos diferentes grupos e (D) tempos de avaliação. Os gráficos mostram média, desvio padrão e * $p<0,05$. 


\section{h) Expressão de RNAm de Tnfrsf11b (Opg) e expressão proteica de OPG}

$\mathrm{Na}$ análise gênica, o grupo $\mathrm{D}$ apresentou um estímulo na expressão de mRNA para o gene Tnfrsf11b (Opg) quando comparado aos grupos C e Dd no período de 3 dias $(p<0,05)$. No período de 7 dias, não se observou diferença estatisticamente significante para os diferentes tratamentos em relação ao gene de interesse $(p>0,05)$. No período de remodelação óssea de 10 dias, pode-se observar uma maior expressão de RNAm para Opg no grupo D comparado ao grupo $C(p<0,05)$, resultado similar ao observado aos 3 dias de avaliação (Figura 22A). Avaliando-se o tempo para os diferentes grupos, pode-se notar que o grupo D apresentou maior estímulo proteico para OPG aos 3 e 10 dias comparado ao tempo de 7 dias $(p<0,05)$ (Figura 22B). Avaliando-se a proteína, notou-se que no tempo de 3 o grupo C e Dd apresentaram maior expressão proteica de OPG comparado ao grupo $D(p<0,05)$. Aos 7 dias os grupos apresentaram expressões proteicas semelhantes $(p>0,05)$. Aos 10 dias o grupo $\mathrm{Cd}$ apresentou maior expressão proteica de Cd comparado ao grupo C e Dd $(p<0,05)$ (Figura 22C). Avaliando-se o tempo nos diferentes grupos, pode-se observar que o grupo $C$ apresentou um estímulo proteico de OPG aos 7 dias comparado ao tempo de 10 dias $(p<0,05)$. O grupo D apresentou um maior estímulo aos 7 dias comparado aos demais tempos de avaliação $(p<0,05)$. O grupo $\mathrm{Dd}$ apresentou padrão de expressão proteica de OPG semelhante ao grupo $C(p<0,05)$, isto é estímulo aos 7 dias comparado aos 10 dias (figura 22D). 
A

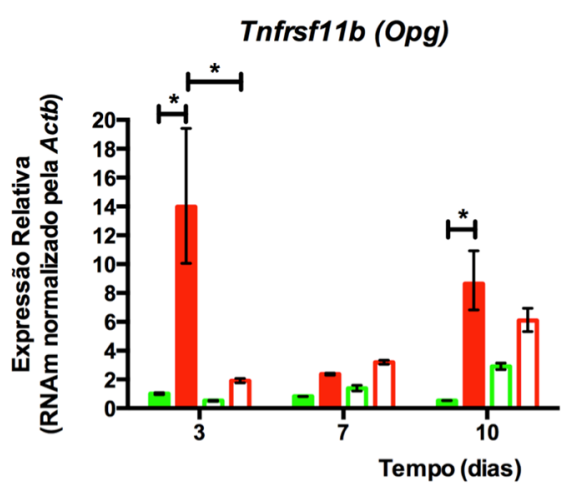

C
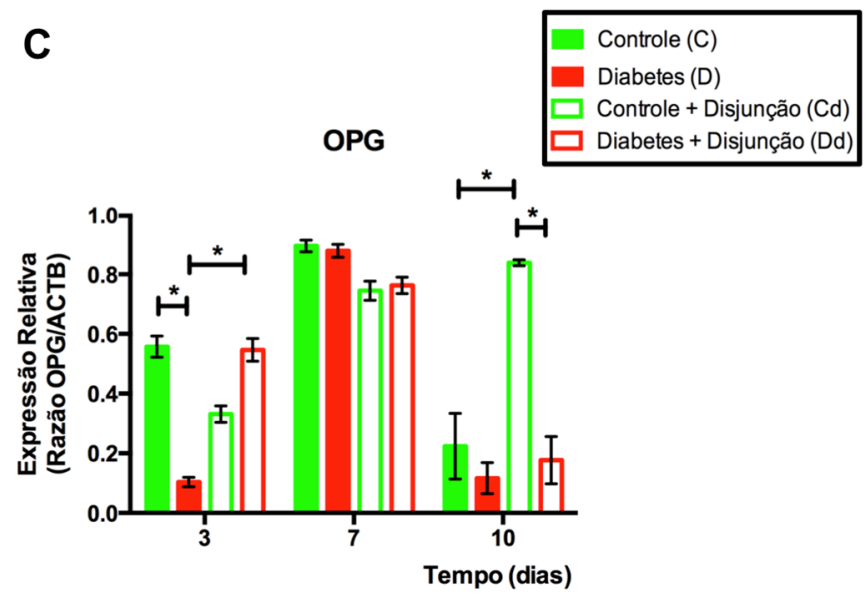

B
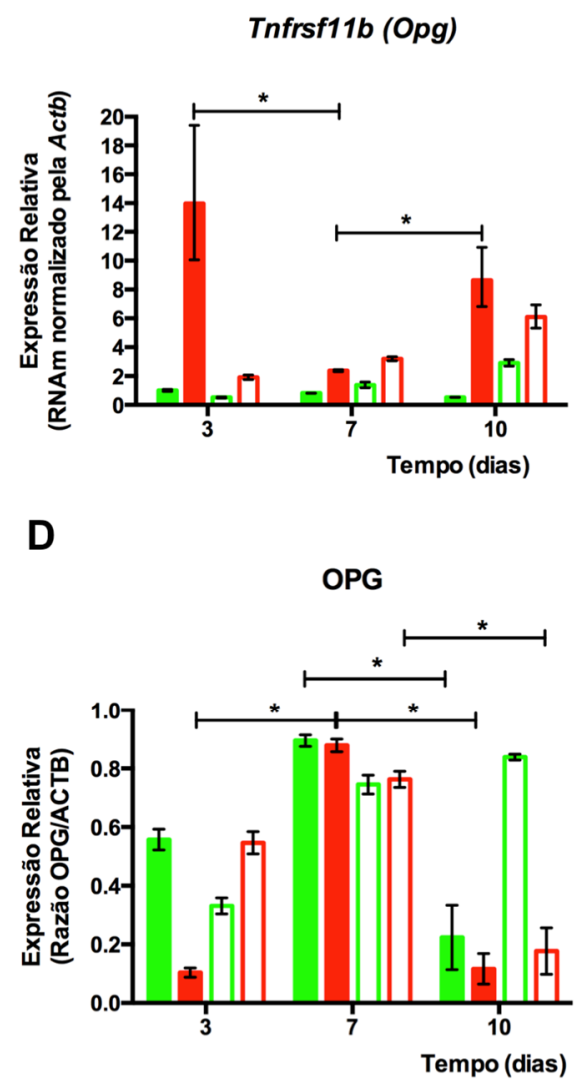

Figura 22: (A) Expressão do RNAm do gene Opg nos diferentes grupos e (B) tempos de avaliação. (C) Expressão proteica de OPG nos diferentes grupos e (D) tempos de avaliação. Os gráficos mostram média, desvio padrão e * $p<0,05$.

\section{i) Razão entre os genes Rankl e Opg e as proteínas RANKL e OPG}

Para avaliar a relação entre os genes Rankl e Opg assim como entre as proteínas RANKL e OPG foi calculada a razão entre os genes e proteínas de interesse. $\mathrm{Na}$ análise gênica, aos 3 dias de avaliação, o grupo $D$ apresentou uma inibição para o processo de reabsorção óssea comparado ao grupo $\mathrm{C}$. Ao passo que os grupos $\mathrm{Cd}$ e $\mathrm{Dd}$ apresesentaram um estímulo para o processo de reabsorção comparado ao grupo C. Aos 7 dias pode-se observar, um resultado similar os 3 dias, exceto para o grupo Dd, que apresentou uma redução da expressão à semelhança do grupo $\mathrm{C}$ no mesmo período. Aos 10 dias, pode-se notar uma inibição do processo de reabsorção óssea no grupo $D, C d$ e Dd comparado ao grupo C (Figura 23A). Na análise proteica, aos 3 dias pode-se notar um estímulo para reaborsção óssea no grupo $\mathrm{D}$ comparado ao grupo $\mathrm{C}$, ao passo que os grupos $\mathrm{Cd}$ e $\mathrm{Dd}$ apresentaram uma inibição para a reabsorção. Ao 7 dias, os grupos D, Cd e Dd apresentaram inibição para reabsorção óssea semelhante ao grupo C. Aos 10 dias o grupo D mostrou estímulo para reabsorção óssea quando comaprado ao grupo $\mathrm{C}$, ao passo que o grupo Dd 
apresetnou uma inibição comparado ao grupo C. O grupo Dd aos 10 dias apresentou resultado semelhante ao grupo C (Figura 23B).

A

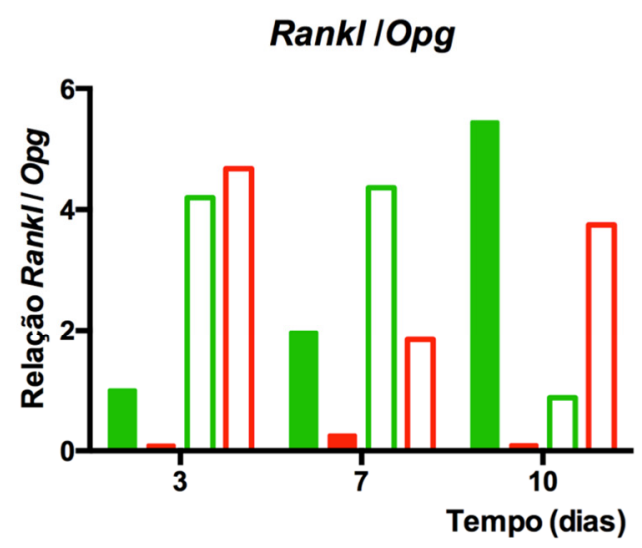

B

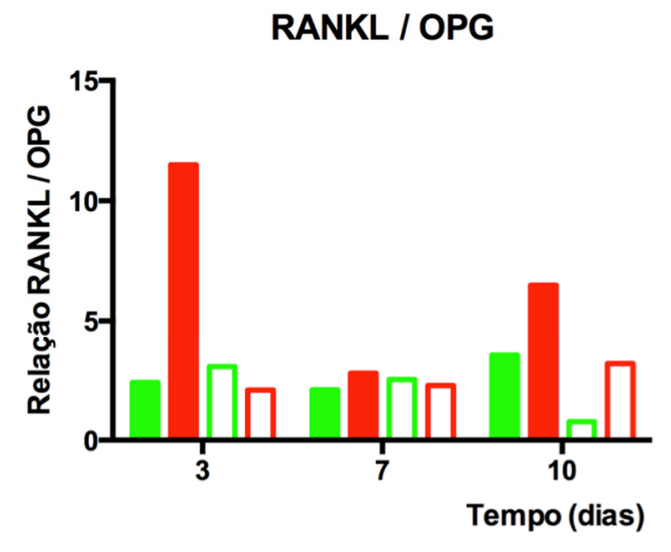

Controle (C)
Diabetes (D)
Controle + Disjunção (Cd)
Diabetes + Disjunção (Dd)

Figura 23: (A) Razão da expressão gênica de RNAm do gene Rankl pela expressão gênica de RNAm do gene Opg nos diferentes grupos em cada tempo de avaliação. (B) Razão da expressão proteica de RANKL pela expressão proteica de OPG nos diferentes grupos em cada tempo de avaliação.

\subsection{Bandas proteicas imunorreativas obtidas pela técnica de Western Blotting}

Abaixo estão exibidas as bandas imunorreativas das proteínas de interesse obtidas pela técnica de Western Blotting, cuja quantificação densitométrica gerou os gráficos da expressão proteica, que foram mostrados nas Figuras 15C, 15D, 16C, 16D, 17C, 17D, 18C, 18D, 19C, 19D, 20C, 20D, 21C, 21D, 22C e 22D. 


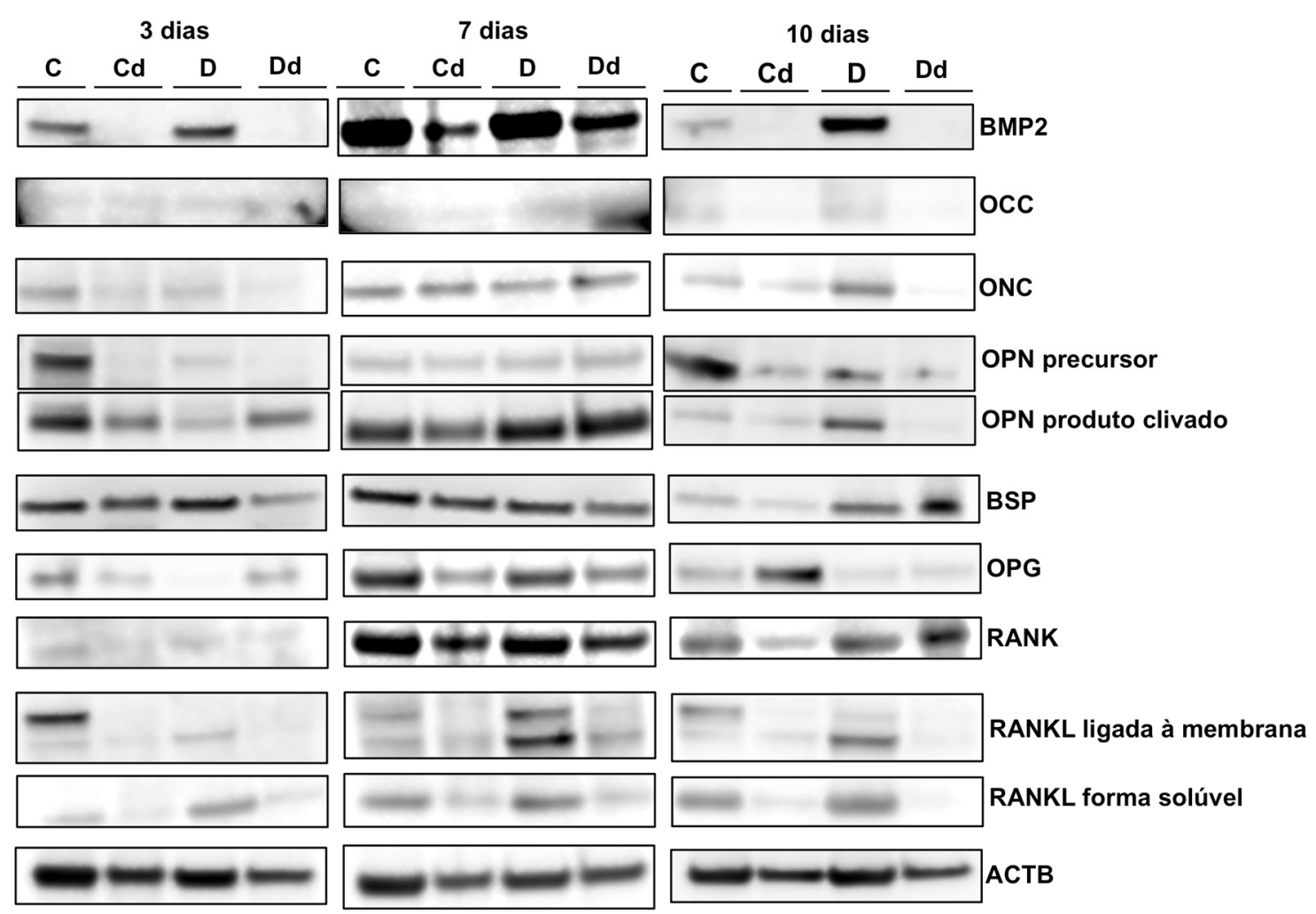

Figura 24: Western Blotting das bandas imunorreativas das proteínas de interesse envolvidas no processo de remodelação óssea nos diferentes grupos e tempos de avaliação. Expressão de BMP2 (60kDa - precursor), OCC (6 kDa), ONC (43 kDa), OPN (66 kDa precursor e 25-55 kDa - produto clivado), BSP (35 kDa), OPG (60 kDa - monômero), RANK (90 KDA), RANKL ligada à membrana (35-40 kDa), RANKL forma solúvel (20$30 \mathrm{kDa})$, ACTB (43kDa). 


\section{Oiscussaño}




\section{DISCUSSÃo}

A aplicação de forças ortodônticas e / ou ortopédicas em pacientes diabéticos tem se tornado uma prática odontológica rotineira, haja vista o crescimento vertiginoso dos pacientes acometidos por esta doença (Amos, 1997; Wild et al., 2004; SBD, 2009; Shaw et al., 2010). Esta nova realidade de pacientes na clínica odontológica implica na necessidade de conhecimentos na área de fisiopatologia do DM, associado aos atuais conhecimentos sobre remodelação óssea, principalmente na área de biologia molecular.

A prevalência de mordida cruzada é de aproximadamente 3\% a 24\% (Reddy et al., 2013; Carvalho et al., 2013; Kumar et al., 2013). Esta maloclusão transversal quando instalada necessita de correção ortodôntica precoce, uma vez que prejudica o crescimento e desenvolvimento crânio-maxilo-facial (Iseri et al., 1998; Ong et al., 2013; Zandi et al., 2014). O conhecimento e o entendimento sobre as alterações provocadas pelo DM no processo de remodelação óssea associado à instalação de forças mecânicas ainda é extremamente escasso e complexo, o que torna o atendimento destes pacientes um verdadeiro desafio na área de Ortodontia.

Diante do exposto, foi realizado neste estudo a avaliação dos diferentes mediadores moleculares que estão envolvidos e modulam o processo de remodelação óssea após ERM em ratos diabéticos tipo 1 induzidos de longo prazo. Estudos experimentais utilizando ratos como animais de estudo oferecem a oportunidade de estudar o processo de remodelação óssea intramembranosa sob diversas condições patológicas isoladamente, além de proporcionar menos interferências de fatores de confusão, que podem estar presentes em humanos.

\subsection{Avaliação Clínica}

A fisiopatologia do DM1 envolve principalmente o hormônio insulina. Este hormônio tem como principal papel aumentar a permeabilidade da membrana celular e a captação de diversas moléculas para o interior das células do organismo, principalmente a glicose. A insulina causa rápida captação, armazenamento e utilização de glicose pelos tecidos do organismo. A glicose é uma molécula utilizada pelas células como fonte de energia, a fim de desempenhar seus diferentes papéis. Quando há destruição das células beta do pâncreas, como na presença de DM1, ocorre uma redução deste hormônio e a sua falta diminui a eficiência da utilização de glicose pelas células. Neste contexto, as células não conseguem 
captar a glicose e o organismo na tentativa de estimular a captação desta molécula, promove um aumento da sua produção. Contudo, como há insuficiência de insulina, a glicose permanece disponível no sangue e assim, instala-se o quadro de hiperglicemia. Desta maneira, inicia-se a poliúria, que visa descartar o excesso de glicose pela urina, a fim de reduzir a elevação da pressão osmótica sanguínea, seguida de um quadro de desidratação intracelular e extracelular associado à polidipsia, polifagia e perda de peso do paciente (WHO, 1999; Guyton e Hall; 2002; SBD, 2009; ADA; 2011; ADA; 2014). No presente estudo foi realizada a indução do DM1 e, a seguir, as avaliações clínicas de perda de peso, glicemia e polidipsia, a fim de confirmar a doença instalada in vivo.

No início do experimento até o segundo dia de avaliação, foi observado que o peso, a glicemia e o consumo hídrico entre os diferentes grupos eram similares. Além disso, também pode-se confirmar que o dispositivo ortodôntico instalado para promover a ERM não alterou o peso dos animais, uma vez que os diferentes grupos submetidos à disjunção apresentaram pesos similares aos grupos sem disjunção durante todo o desenvolvimento experimental, dados que confirmam achados anteriores (Sawada e Shimizu, 1996; Stuani, 2011; Takenouchi et al., 2014). Desta maneira, visto que não houve diferença do peso entre os grupos com ou sem disjunção, também pode-se afirmar que, a mudança na consistência da ração (moída) não foi um procedimento que interferiu no peso dos animais submetidos à disjunção. Estes resultados reforçam que este dispositivo utilizado para ERM tornou o procedimento clínico seguro e reprodutível, além de confirmar as assertivas de que a ERM é um procedimento que não afeta a saúde do animal de um modo geral (Takenouchi et al., 2014) e provavelmente não provoca desconforto doloroso (Hass 1961).

Por outro lado, após 28 dias de experimento, pode-se observar mudanças nas avaliações clínicas entre os diferentes grupos ao longo do tempo. Aos 28 dias após a indução do DM, houve uma redução do peso corporal dos animais dos grupos diabéticos (D e $D d$ ) comparado aos grupos controle e veículo (com e sem disjunção), assim como nos tempos 3 , 7 e 10 dias após a data da instalação do dispositivo ortodôntico. Estes resultados assemelham-se aos resultados encontrados em estudos prévios (Jandeleit-Dahm et al., 2000; Mishima et al., 2002; Freitas et al., 2007; Motyl et al., 2009; Sabino-Silva et al., 2009; Okamoto et al, 2011; Villarino et al., 2011; Hie et al., 2011; Silva et al., 2012; Hu et al., 2013; Du et al., 2014).

A polidipsia foi encontrada nos animais com DM, submetidos ou não à disjunção, nos mesmos tempos de avaliação que foram observadas as demais alterações clínicas descritas. Este quadro clínico não esteve presente nos animais sem DM. Ainda, a hiperglicemia encontrada nos grupos diabéticos ( $D$ e $D d$ ) foi diferente dos valores normoglicêmicos encontrados nos demais grupos, submetidos ou não à disjunção, no $28^{\circ}$ dia pós-indução do DM e nos dias 3, 7 e 10 dias de eutanásia após ERM. Estes resultados confirmam a instalação 
do DM, validando o modelo de estudo de acordo com pesquisas recentes (Silva et al., 2012; Hu et al., 2013; Du et al., 2014).

Existem diversas formas de indução experimental do DM descritas na literatura, tais como: infecções virais, pancreatectomia parcial, uso de hormônios anti-insulínicos, uso excessivo de hidrocortisona (hormônio adenocorticotrófico), o aloxano e a STZ (Tominaga, 2007; Shankaracharya et al., 2012). Neste estudo, optou-se pelo uso da droga STZ. Esta substância é um antibiótico de ocorrência natural, derivado do Streptomyces acromogenes, que apresenta uma ação diabetogênica em animais, uma vez que destrói as células beta do pâncreas. Esta toxina quando injetada em ratos produz uma resposta insulínica prejudicada, assim como baixa tolerância à glicose e um elevado nível glicêmico basal (Blondel, Bailbe, Portha, 1989). As drogas diabetogênicas STZ (Jandeleit-Dahm et al., 2000; Mishima et al., 2002; Holzhausen et al., 2004; Botolin e McCabe, 2006; Fowlkes et al., 2008; Motyl et al., 2009; Braga et al., 2011; Hie et al., 2011; Zhang, Li, Bi, 2011; Ju et al., 2012; Silva et al., 2012; Hu et al., 2013) e o aloxano (Freitas et al., 2007; Sabino-Silva et al., 2009; Okamoto et al, 2011; Maia et al., 2014) têm sido bastante utilizadas em modelos de pesquisa em animais atualmente.

Os quadros clínicos de perda de peso, polidipsia e glicemia sanguínea casual acima de $200 \mathrm{mg} / \mathrm{dl}$ são sinais clínicos relatados na literatura e que confirmam o diagnóstico de DM (Guyton e Hall, 2002; SBD, 2009; ADA, 2011; ADA, 2014, Al Yaarubi et al., 2014; LolukoSodipe et al., 2014). Estes achados também foram relatados na presente pesquisa e confirmaram que a indução do DM obtido nos animais deste estudo utilizando a STZ foi alcançada com sucesso e, portanto, comprova que esta doença sistêmica estava instalada em todos os animais dos grupos diabéticos ( $D$ e $D d)$, a partir do segundo dia após indução.

\subsection{Avaliação Molecular (Expressão Gênica e Proteica) e Análise Histológica}

Os eventos do processo de remodelação óssea têm sido amplamente investigados na área de Ortodontia, porém o conhecimento sobre os genes e proteínas que regulam a osteogênese durante a utilização de forças ortopédicas em diabéticos, ainda não foram completamente investigados e esclarecidos. Na literatura há apenas uma pesquisa sobre a resposta óssea a forças ortodônticas de grande magnitude, aplicada em molares de ratos diabéticos de longo prazo. Entretanto, este estudo utilizou apenas avaliações histológicas e histomorfométricas para análise do processo de remodelação óssea (Villarino et al., 2011). Na presente pesquisa foi utilizado um modelo de remodelação óssea associado à ERM in vivo, previamente descrito na literatura (Sawada e Shimizu, 1996; Stuani, 2008; 
Stuani, 2011; da Silva et al., 2012; Pingueiro-Okada, 2012; Stuani, 2012; Takenouchi et al., 2014; ), porém os efeitos do diabetes na resposta tecidual ainda não haviam sido investigados. Neste contexto foram estudados genes e proteínas como RANK, RANKL, OPG, ONC, OCC, BSP, OPN e BMP2, que são marcadores do turnover e do processo de reparo ósseo (Gerstenfeld et al., 2003), a fim de entender e possivelmente esclarecer, em nível molecular, como ocorre o processo de remodelação óssea em ratos diabéticos submetidos à disjunção.

As forças mecânicas são transmitidas para o microambiente da matriz extracelular, levando à modificações na membrana celular, citoesqueleto, síntese de proteínas da matriz nuclear e alterações no padrão de expressão gênica (Krishnan e Davidovitch, 2006). As mudanças na expressão gênica frente a forças mecânicas podem modular positiva ou negativamente a viabilidade, proliferação e na diferenciação celular, que são essenciais para o mecanismo de movimentação ortodôntica (Meikle, 2006).

As células eucarióticas expressam informações genéticas baseada no dogma central da biologia molecular. Este dogma consiste em que uma sequência de nucleotídeos de uma região específica da molécula de DNA em um cromossomo é inicialmente copiada sob a forma de RNA durante o processo de transcrição. As cópias de RNA, chamadas de moléculas de RNAm, provenientes de segmentos de DNA, são utilizadas como moldes para a síntese proteica durante o processo de tradução. A transcrição do DNA em RNAm dos eucariotos é realizada pela enzima RNA polimerase II. Os RNAms processados dentro do núcleo são transportados para o citoplasma celular e, após maturação, são traduzidos em proteínas pelos ribossomos. A transcrição e a tradução são os meios pelos quais se estuda a expressão gênica das diferentes células (Alberts et al., 2010).

As células podem alterar o padrão de expressão gênica em resposta à mudanças em seu meio ambiente. Uma célula pode regular a expressão de cada um de seus genes de acordo com a sua necessidade, através do controle da produção de seus RNAs ou pela capacidade de alterar seus níveis proteicos (Alberts et al., 2010). Contudo, é necessário esclarecer que os RNAm de genes estimulados ou inibidos nem sempre correspondem ao mesmo perfil proteico. A expressão gênica pode ser regulada em diferentes etapas no caminho que vai do DNA ao RNA até a produção de proteínas. Há uma complexidade de eventos que podem modular a expressão de diferentes genes e proteínas nas células. Desta maneira, torna-se importante enfatizar que existem diversos mecanismos para regulação da expressão gênica, tais como (1) controle transcricional (controlando quando e como um determinado gene pode ser transcrito), (2) controle pós-transcricional, isto é, controle do processamento de RNA, transporte de RNA e controle da sua localização no citoplasma, (3) controle traducional, (4) controle da degradação do RNAm e (5) controle da atividade proteica (Alberts et al., 2010). 
Assim, os processos de regulação gênica e tradução proteica não necessariamente são o reflexo um do outro. No modelo utilizado no presente estudo, o padrão de formação ou reabsorção óssea deve ser interpretado juntamente com os resultados obtidos em nível molecular. Isto porque a expressão gênica reflete o status da atividade celular, ao passo, que a expressão proteica reflete o status da atividade celular associado ao acúmulo ou não de proteína no tecido ao longo do tempo. Visto que existem diferentes mecanismos complexos que controlam a expressão gênica e proteica, a seguir foram discutidos os resultados obtidos no presente estudo com os diferentes achados encontrados previamente na literatura. Inicialmente serão discutidos (1) os efeitos do diabetes no metabolismo do tecido ósseo, (2) os efeitos da expansão rápida da maxila no metabolismo ósseo e, a seguir, (3) os efeitos da expansão rápida da maxila em animais diabéticos comparativamente a animais sem diabetes.

Os resultados do presente trabalho mostraram que na expressão gênica no tempo de 3 dias no grupo diabético (D) houve expressões relevantes para Bsp, Opn, Onc, Occ, Rank e Opg comparado ao grupo controle (C). Estes resultados sugerem que, no período inicial de reparo, há expressão de genes relacionados com o processo de formação óssea, na tentativa de evitar um processo de reabsorção óssea. Contudo, na expressão proteica o que observamos foi um outro quadro molecular. Aos 3 dias, no grupo diabético, foi observado estímulo para BMP2 e uma inibição de OPG, comparado aos grupos controle e diabético com disjunção. Houve uma inibição de OCC comparado ao grupo diabético com disjunção e uma inibição de OPN comparado ao grupo controle. Neste período, a expressão proteica pareceu promover o processo de reabsorção óssea.

Aos 7 dias no grupo diabético observamos uma inibição gênica de Bmp2 e Occ comparado ao grupo controle, além de uma inibição gênica de Bsp e Rankl comparado ao grupo diabetes submetido à disjunção (Dd). Assim, aos 7 dias no grupo diabético foi observado uma regulação gênica que pode ter desfavorecido o processo de remodelação óssea observado histologicamente. Na avaliação proteica deste período, no grupo diabético, o padrão de expressão de BMP2 foi semelhante ao período de 3 dias e também foi observado estímulo à produção da proteína RANKL. Desta maneira, a regulação proteica neste período foi direcionada no sentido de promover o processo de reabsorção óssea, associado aos achados histológicos.

Aos 10 dias, no grupo diabético foi observada a inibição de Bmp2 comparado ao grupo controle e ao grupo diabético com disjunção (Dd), além disso, houve uma inibição de Rankl e um estímulo de Bsp comparado ao grupo diabético com disjunção (Dd) e um estímulo de Opg comparado ao grupo controle. Neste período ficou evidente sinalizações para o processo formação óssea no grupo diabético comparado ao diabético com disjunção e mecanismo moleculares para evitar a reabsorção comparado ao grupo controle. Os demais genes não sofreram modulações significativas nas suas expressões nos diferentes tempos de 
análise. Na análise proteica no período mais tardio, foi observado novamente uma sinalização para BMP2 semelhante ao que foi encontrado nos períodos de 3 e 7 dias, isto é, estímulo proteico para BMP2 comparado ao grupo controle e diabético com disjunção, assim como um estímulo de BSP comparado ao grupo controle. Assim, é possível notar que aos 10 dias houve um maior estímulo de proteínas relacionadas ao processo de formação óssea. As demais proteínas não sofreram alterações significativas na suas expressões nos diferentes tempos de análise.

Contudo, histologicamente o que foi observado no grupo diabetes em todos os períodos, foi a presença de uma maior faixa de tecido imaturo e de áreas de remodelação ativa, comparado aos grupos controle (C) e veículo (V). Neste grupo o que predominou foi o atraso na maturação óssea ao longo do tempo. Desta maneira, nossos resultados são similares aos encontrados na literatura, visto que alguns autores relataram que pacientes com DM apresentam um turnover ósseo diferente de pacientes sem esta doença (Okasaki et al., 1997; Thraikill et al., 2005; Starup-Linde, Lykkeboe, Handberg, 2014), principalmente relacionado a perda óssea; reduzida óssea, osteopenia e osteoporose (Räkel et al., 2008). A hiperglicemia provavelmente atua como um fator endógeno para o estímulo da mineralização, porém favorece uma reduzida qualidade mineral (Garcia-Hernández et al., 2012). Este resultado suporta a hipótese de que no grupo diabético houve sinalização para formação óssea, contudo o processo foi atrasado. Provavelmente este resultado histológico tenha sido devido a qualidade óssea prejudicada encontrada em diabéticos (Dayem et al., 2011; Hamann et al., 2011; Garcia-Hernández et al., 2012; Haug et al., 2014).

Em uma pesquisa prévia foram avaliadas 47 crianças e adolescentes com DM1, dos quais 27 pacientes foram diagnosticados com osteopenia e 21 pacientes com osteoporose, indicando que pacientes com DM1 apresentam baixa densidade óssea mineral, reduzida formação óssea e alta concentração de biomarcadores de reabsorção óssea no plasma (Dayem et al., 2011). Além disso, outros autores também realizaram estudos in vivo (Hamann et al., 2011; Coe, Zhang e Mccabe, 2013) e relataram que o DM alterou o processo de formação óssea e promoveu a reabsorção óssea. Por outro lado, o controle glicêmico com insulina restaurou o metabolismo ósseo em níveis de normalidade. Análises histomorfométrica e radiográfica em animais diabéticos mostraram menor formação óssea, maior formação de cartilagem e de tecido conjuntivo fibroso aos 7 e 14 dias após a fratura de tíbia em ratos com DM quando comparado aos animais controle (Amorin et al., 2008).

Contudo, os mecanismos de perda e alteração da remodelação óssea no DM ainda são desconhecidos. Especulam-se que efeitos diretos ou indiretos no restabelecimento de insulina poderiam estar envolvidos neste processo (Botolin e McCabe, 2006). Ainda, a formação óssea reduzida poderia ser resultado do aumento da apoptose de células osteoblásticas ou do aumento da atividade de reabsorção óssea pelo recrutamento ou função 
alterada dos osteoclastos (Mishima et al., 2002; He et al., 2004, Suzuki et al. 2005; Liu et al., 2006; Hie et al., 2007)

Animais DM2 apresentam reduzida densidade mineral óssea, baixo volume de tecido ósseo mineralizado, número e espessura trabecular reduzida possivelmente devido à diferenciação osteoblástica prejudicada sem alteração da atividade osteoclástica. Estes resultados indicam que a osteoblastogênese suprimida é responsável pelo mecanismo da massa óssea reduzida e regeneração óssea prejudicada em defeitos ósseos de ratos com DM2 (Hamann et al., 2011). No presente trabalho observamos uma sinalização para formação óssea no grupo diabético contudo, o processo de reparo foi comprometido, provavelmente devido uma reduzida diferenciação osteoblástica.

No presente estudo, o que se observou no contexto molecular no grupo diabético, foi uma regulação gênica e proteica na tentativa de equilibrar o processo de osteogênese e osteoclastogênese ao longo do tempo, exceto na avaliação gênica aos 7dias que predominou uma redução de genes envolvidos com o processo de formação óssea. Entretanto histologicamente observamos um comprometimento do processo de remodelação óssea em todos os períodos avaliados. Uma provável hipótese para essa diferença nos nossos resultados moleculares comparado aos resultados histológicos, é que no tecido sutural provavelmente houve a associação de menor atividade, recrutamento e diferenciação osteoblástica e/ ou osteoclástica, juntamente com a sinalização gênica e acúmulo proteico relacionados ao processo remodelação óssea. Estes eventos podem ter prejudicado a maturação óssea até o período de 10 dias pós ERM. Da mesma maneira a não coincidência entre algumas sinalizações moleculares com os resultados histológicos podem ser atribuídos aos eventos de regulação pós-transcricional, traducional, controle da degradação do RNAm e/ ou controle da atividade proteica. Entretanto, outros períodos de avaliação devem ser investigados com a finalidade de confirmar a longo prazo a formação óssea prejudicada. Além disso, existe evidência de que o hormônio insulina e a glicose influenciam a função e a atividade de osteoblastos e osteoclastos, visto que alterações na concentração destas moléculas interferem na transcrição gênica e tradução das proteínas, resultando em padrões de reparo teciduais prejudicados ou atrasados (Xu et al., 2013). Em condições hiperglicêmicas há inibição da maturação e da função de osteoblastos e osteoclastos, uma vez que a ação combinada entre osteoblasto e osteoclasto é necessária para o adequado desenvolvimento esquelético (Dienelt e Nieden, 2011). Tais resultados poderiam explicar a remodelação óssea atrasada observada no presente estudo no grupo diabético.

O DM tipo 1 induzido influencia negativamente o processo de turnover do osso alveolar e esse efeito pode ser revertido pela insulinoterapia (Mishima et al., 2002). Similarmente, a ablação medular da tíbia em ratos diabéticos levou a menor formação óssea na área. Este déficit ficou evidente pela presença de tecido mesenquimal imaturo e diminuição 
da expressão de osteocalcina e colágeno tipo 1, porém sem regulação gênica de $B m p 2$. A insulinoterapia reverteu substancialmente o efeito do diabetes na expressão da osteocalcina e do colágeno tipo 1 (Lu et al., 2003). No gap de distração óssea de animais diabéticoinduzidos, observou-se menor neoformação óssea na análise histológica e radiográfica quando comparado aos ratos não-diabéticos e tratados com insulina. As concentrações sorológicas de marcadores ósseos como a osteocalcina foram reduzidas nos animais diabéticos e normalizadas no tratamento com insulina. Além disso, houve menor volume ósseo no fêmur contralateral de ratos diabéticos-induzidos (sem distração osteogênica) quando comparado ao fêmur de ratos insulinotratados e controle não-distraídos. Os achados na imunohistoquímica sugeriram que o eixo de sinalização da insulina poderia ser um componente fisiológico de cada fase da osteogênese durante a distração osteogênica. Assim, provavelmente nos animais não-tratados, a condição de diabetes prejudicou a neoformação óssea no gap de distração osteogênica e a insulina administrada sistemicamente restaurou o processo de formação óssea em animais diabéticos diretamente via precursores osteoblásticos ou da maturação de osteoblastos, ou indiretamente, via normalização da glicemia ou de outros parâmetros metabólicos (Thrailkill et al., 2005).

Todos estes achados prévios corroboram com os dados do presente estudo, uma vez que no grupo diabético havia mais tecido imaturo e áreas de remodelação óssea ativa. Provavelmente o hormônio insulina deve apresentar um papel importante no processo de remodelação óssea, uma vez que parece restaurar condições do tecido ósseo e as sinalizações moleculares osteogênicas. Entretanto, no presente trabalho não foi utilizado o hormônio insulina, a fim de reverter o quadro diabetogênico e avaliarmos os seus efeitos osteogênicos. Desta maneira, é necessário mais estudos utilizando insulinoterapia, a fim de avaliar os mecanismos que este hormônio apresenta na reversão do quadro de DM que foi observado na nossa pesquisa e por diversos autores (Mishima et al., 2002; Lu et al., 2003; Thrailkill et al., 2005).

Alguns autores estudaram o DM avaliando diferentes genes e proteínas relacionadas ao processo de remodelação óssea em diferentes tempos de análise utilizando diversos protocolos.

No tecido de ratos com periodontite induzida experimentalmente, o DM prolongou a inflamação, a osteoclastogênese e reduziu a quantidade de osso novo, de osteóide e o número de osteoblastos. Além disso, não foi possível observar diferença de expressão em diversos genes nos grupos diabéticos comparado ao baseline, inclusive do gene da Bmp2 (Pacios et al., 2012).

A distração osteogênica em ratos diabéticos, diabéticos tratados com insulina e ratos controles mostrou resultados similares. No grupo diabético foi observado uma inibição dos fatores de transcrição para diferenciação osteoblástica. Contudo, não conseguiram observar 
diferença entre os grupos na análise da expressão gênica de Bmp2 (Fowlkes et al., 2008). Estes resultados corroboram com os achados prévios de ablação óssea de tíbia (Lu et al., 2003), que observaram uma redução na expressão dos fatores de transcrição para diferenciação osteoblástica nos ratos diabéticos, porém não houve diferença na expressão do gene Bmp2 nos animais diabéticos e controle. Entretanto, na presente pesquisa foi possível detectar ao longo do tempo uma regulação gênica e proteica de BMP2 neste grupo. Por outro lado, quando foi avaliado o impacto do DM2 no metabolismo e regeneração óssea em defeito ósseo crítico de fêmur (Hamann et al., 2011), pode-se observar que a expressão gênica de Bmp2 estava reduzida nos ratos diabéticos após 12 semanas de avaliação. Esta pesquisa corrobora com os resultados do presente estudo que mostrou uma redução da expressão gênica de $B m p 2$ em períodos mais tardios da remodelação óssea em ratos diabéticos, porém não foi observado o mesmo padrão na expressão proteica. No tecido ósseo, estas glicoproteínas são produzidas pelas células osteoprogenitoras, osteoblastos, condrócitos, plaquetas, células endoteliais e são secretadas pela matriz óssea que funciona como um reservatório de BMPs durante o reparo e a remodelação óssea (Carreira et al., 2014). Desta maneira, isto poderia explicar porque no presente estudo em alguns grupos não houve uma correlação da expressão gênica de Bmp2 com o padrão observado nas expressão proteica, haja vista que a expressão proteica pode ser o reflexo do acúmulo de BMP2 na área.

Em relação à expressão gênica e proteica de BSP alguns estudos corroboram com os resultados do presente trabalho. Um estudo recente mostrou que incubando células osteoblásticas humanas com altas concentrações de glicose (216 a $432 \mathrm{mg} / \mathrm{dl}$ ), foi observado expressões elevadas de RNAm de lbsp nos períodos de 7 e 14 dias de cultura, comparado aos grupos normoglicêmicos, assim como também foi encontrado expressões elevadas de outros genes como a Occ (Garcia-Hernández et al., 2012). Expressões gênicas elevadas de Ibsp, Spp1 (Opn) e Runx2 nos grupos diabéticos também foram observadas em tecido ósseo coletado em cirurgia ortopédicas de pacientes com DM2 comparado aos pacientes normoglicêmicos (Haug et al., 2014). Contudo, no modelo de remodelação óssea utilizando distração osteogênica durante 14 dias, observou-se uma inibição da expressão gênica de $I b s p$ no grupo diabético induzido (Fowlkes et al., 2008). O presente estudo corrobora com os resultados descritos sobre o aumento da expressão gênica de Ibsp em diabéticos, uma vez que foi observado um estímulo na expressão deste gene no grupo diabético comparado aos grupos controle e diabético com disjunção aos 3 dias, assim como neste grupo comparado ao grupo diabético com disjunção aos 10 dias.

Diversos estudos tem demonstrado que a OPN parece ter um papel importante na regulação da resposta celular em diferentes condições de estresse químico, físico e mecânico, além de ter papel crítico na remodelação óssea induzida (Denhart, Noda, 1998; Terai etal., 1999; Nomura et al., 2000). Há relatos sobre o estímulo de OPN durante injúria cardiovascular 
(Kossmehl et al., 2005) e aumento de sua expressão em macrófagos alveolares de pacientes com doença pulmonar obstrutiva (Heguy et al., 2006). Em pacientes com DM2 foi observado expressões gênicas elevadas de Opn (Haug et al., 2014). Este estímulo gênico de Opn também foi encontrado no presente trabalho no período de 3 dias no grupo diabético, porém este resultado não foi refletido na avaliação proteica deste período, devido provavelmente a um controle pós-transcricional, traducional, controle da degradação do RNAm e/ ou controle da atividade proteica. Além disso, nos tempos mais tardios não houve modulação gênica e proteica de OPN. Desta maneira, na presença de DM, a osteopontina pareceu estar mais envolvida nos períodos iniciais do processo de reparo. A nossa pesquisa parece também concordar com a hipótese de que elevadas expressões de genes osteogênicos colaboram com a baixa qualidade óssea em diabéticos, haja vista que na histologia do nosso estudo houve um atraso no reparo ósseo, provavelmente devido a qualidade óssea ser deficiente até o período de 10 dias.

A ONC tem sido implicada na regulação do turnover da matriz, na migração e proliferação celular (Jandeleit-Dahm et al., 2000; Kos e Wilding, 2010), e devido a estas propriedades, esta proteína tem participação no processo de reparo, angiogênese, inflamação e na tumorigênese (Brekklen, Sage, 2001). Além disso a ONC tem sido associada com as complicações no DM, como retinopatia e nefropatia (Kos e Wilding, 2010). No presente estudo a osteonectina mostrou um estímulo gênico no grupo diabetes apenas aos 3 dias, além de não ser observado este mesmo padrão na expressão proteica, isto é, neste período o DM pareceu modular apenas a expressão gênica de Onc e não influenciou a sua expressão proteica. Estes resultados nos levam a acreditar que o DM regula este biomarcador apenas nos períodos iniciais de reparo. Além disso, controles pós-transcrição, tradução e outras vias de sinalização parecem ter atuado na regulação molecular de osteonectina, assim como observado na sinalização de osteopontina.

A expressão gênica e proteica de Onc em vasos do mesentério de ratos diabéticos foi avaliada através de Northern Blot, hibridização in situ e imunofluorescência (JandeleitDahm et al., 2000). A expressão gênica e proteica de ONC nos ratos diabéticos nos períodos iniciais de avaliação foi maior comparado ao controle. Este trabalho corrobora com o estudo que observou maior expressão gênica e proteica de $\mathrm{ONC}$ em pacientes e ratos com retinopatia diabética (Watanabe et al., 2009) e com os resultados encontrados em camundongos diabéticos nulos e selvagens para avaliação da nefropatia diabética (Taneda et al., 2003). Estes autores sugeriram que a expressão gênica de Onc estava envolvida com o desenvolvimento da retinopatia e nefropatia diabética. Os resultados da expressão de osteonectina de trabalhos prévios suportam os achados da presente pesquisa, uma vez que encontramos maior sinalização de osteonectina nos períodos iniciais do reparo após 28 dias de indução diabética, porém não observamos a mesma sinalização para avaliação proteica. 
Provavelmente, esta diferença pode estar no tipo de tecido que foi analisado. Além disso, podemos sugerir que a osteonectina possa estar contribuindo ou favorecendo os danos ósseos presentes no grupo diabético, assim como observado nas sinalizações de sialoproteína óssea e osteopontina.

Por outro lado, há autores que mostraram a redução de genes osteogênicos como a Onc, aumento de genes adipogênicos e uma inibição na maturação e crescimento de células osteoblásticas humanas em altas concentrações de glicose em experimento de cultura de células (Wang et al., 2010). Em um estudo recente a expressão gênica de Onc foi bastante variada em diferentes tecidos quando da presença de DM. Neste trabalho também foi observado que os níveis deste gene estavam reduzidos nas ilhotas pancreáticas de doadores diabéticos comparados aos saudáveis e também observaram que houve uma correlação entre a secreção de insulina estimulada por glicose e a expressão de Onc (Harries et al., 2013). Desta maneira, é provável que o tecido ósseo em ratos diabéticos também apresente diferentes expressões deste gene e mais uma vez, a insulina parece ter papel importante nesta modulação.

A expressão proteica de ONC foi avaliada no plasma de pacientes com DM2 e pacientes saudáveis. Estes pacientes apresentavam altos níveis desta proteína e estes níveis séricos estavam relacionados com o índice de massa corpórea, gordura, níveis de insulina em jejum e triglicérides (Wu et al., 2011), isto é, pareceu existir uma potencial ligação entre ONC e a patogênese da DM2. Estes resultados da expressão proteica de ONC não foram observados na presente pesquisa, e esta diferença pode ser devido também ao tipo de diabetes estudado. Entretanto, acreditamos que esta proteína esteja envolvida na patogênese do DM1 e esteja contribuindo para o reparo ósseo compremetido.

A osteocalcina (OCC) é uma proteína não colágena da matriz de tecidos mineralizados. Esta proteína é sintetizada pelos osteoblastos, odontoblastos e condrócitos hipertrofiados. A OCC é considerada um marcador da atividade e função dos osteoblastos, um marcador tardio de osteoblastos diferenciados ou maduros (Tanaka et al., 2007), marcador de formação óssea (Motyl et al., 2009), além de participar no processo de reabsorção óssea e mineralização (Roach, 1998). No presente trabalho no grupo diabético houve modulação de osteocalcina apenas na expressão gênica. Foi observado um estímulo gênico de Occ no período de 3 dias e inibição aos 7 dias no grupo diabético. Estes resultados mostram que a osteocalcina é regulada genicamente em períodos mais iniciais do reparo ósseo no DM, porém o que foi predominante no resultado histológico foi o comprometimento da formação óssea neste grupo, o que corrobora com os resultados gênicos de Occ aos 7 dias.

O array de genes osteogênicos no modelo de distração osteogênica realizado em ratos diabéticos, diabéticos tratados com insulina e ratos controles, identificou 13 genes inibidos no grupo diabético sem tratamento, e dentre estes a expressão gênica de Occ 
também havia sido inibida (Fowlkes et al., 2008). Estes achados suportam os estudos prévios que avaliaram a OCC sérica em camundongos diabéticos durante distração osteogênica (Thrailkill et al., 2005) e OCC em pacientes com DM1 (Okazaki et al., 1997; Dayem et al., 2011). O estudo in vitro sobre expressão gênica de marcadores iniciais e tardios da maturação osteoblástica em DM de longo prazo mostrou que houve uma redução da expressão de Occ apenas no período de 29 dias, em contraste com os aumentos da expressão dos marcadores iniciais da maturação osteoblástica no mesmo período (Botolin e McCabe, 2006). Este estudo também observou um aumento da expressão de genes relacionados a diferenciação de adipócitos no DM de longo prazo, além de observar que no DM de curto prazo (48h) a expressão de Occ foi suprimida. Desta maneira, este estudo pareceu mostrar uma influência dos níveis glicêmicos nos marcadores osteoblásticos e marcadores de diferenciação de adipócitos de acordo com o tempo de evolução do DM. Além disso, suportou os resultados do presente trabalho que observou uma redução de osteocalcina aos 7 dias no grupo diabético.

O metabolismo ósseo também foi avaliado em camundongos diabéticos utilizando marcadores séricos e de expressão gênica. Os autores observaram que após 5 dias de indução da doença era possível identificar reduções nas expressões sérica e gênica de Occ. (Motyl et al., 2009). Em estudo mais recente os achados de expressão gênica e proteica de OCC em animais jovens diabéticos também mostrou uma redução deste marcador (Coe, Zhang e Maccabe., 2013), assim como, foi observado o mesmo padrão de expressão gênica de Occ em defeito ósseo crítico de fêmur em ratos diabéticos tipo 2 (Hamann et al., 2011). Apesar de alguns trabalhos mostrarem que a expressão gênica e proteica de OCC é diminuída durante o DM, alguns autores (Garcia-Hernández et al., 2012) observaram um padrão similar aos resultados gênicos encontrados na presente pesquisa no período de 3 dias. Estes autores observaram que em altas concentrações de glicose em células osteoblásticas humanas havia elevadas expressões gênicas de Occ nos períodos de 7 e 14 dias de cultura. Tais diferenças no período de expressão pode ser devido ao presente estudo ser in vivo e DM de longo prazo.

O receptor ativador do Fator Nuclear Kappa B (RANK), o ligante de RANK (RANKL) e a osteoprotegerina (OPG), fornecem a base celular e molecular para o cross-talk entre osteoblasto e osteoclasto, células cruciais no processo de remodelação óssea (Lima Guedes et al., 2008). O RANK, que pertence a superfamília do fator de necrose tumoral (TNF), está presente na superfície dos precursores de osteoclastos e é ativado pelo RANKL. Esta interação induz a diferenciação de monócitos em osteoclastos, assim iniciando o processo de reabsorção. O sistema OPG/RANK/RANKL controlam o processo de remodelação e fazem parte do metabolismo ósseo. O RANKL é um agonista que regula aspectos importantes dos osteoclastos como diferenciação, fusão, sobrevivência, ativação e apoptose. Uma vez que ativação de RANK por RANKL inicia o processo de reabsorção óssea, este mediador solúvel pode ser considerado um marcador de reabsorção óssea. Por outro lado, a OPG, também 
membro da superfamília do TNF, é um receptor solúvel secretado, que é um antagonista do RANKL, uma vez que interrompe esta ativação pela ligação direta ao RANKL evitando o processo de reabsorção óssea, isto é, a OPG regula negativamente o processo de osteoclastogênese (Horowitz et al., 2001).

No presente estudo, observamos no grupo diabético um estímulo gênico de Rank apenas no período de 3 dias no grupo diabético, entretanto não foi observado esta mesma sinalização para expressão proteica. Além disso, no grupo diabético foi observado inibição gênica de Rankl aos 3 dias comparado ao grupo diabético com disjunção e um estímulo desta proteína no tempo de 7 dias comparado ao controle e ao grupo diabético com disjunção. Para a osteoprotegerina no grupo diabético, houve uma grande estímulo gênico aos 3 e 10 dias e uma inibição proteica aos 3 dias. Estes resultados nos leva a acreditar que nos períodos iniciais há um estímulo gênico para evitar a reabsorção óssea, porém este estímulo não foi refletido na expressão proteica.

A relação gênica e proteica de RANKL e OPG (razão RANKL/OPG) tem o intuito de mostrar se o metabolismo ósseo estava mais direcionado para a formação ou reabsorção óssea. Quando analisamos no grupo diabético a relação gênica de Rankl / Opg, observamos uma sinalização para evitar o processo de reabsorção óssea em todos os tempos de avaliação. Contudo, estes resultados não foram refletidos na relação proteica de RANKL/OPG no período de 3 dias e 10 dias, períodos quando se notou uma atividade osteoclástica no grupo DM. Provavelmente o que foi observado na histologia foi reflexo do estímulo proteico de RANKL aos 7 dias e na relação proteica de RANKL/OPG observada no período de 3 dias e 10 dias, associado à redução de alguns genes relacionados à osteogênese no período de 7 dias, uma vez que a histologia nos mostrou um reparo ósseo comprometido no DM comparado aos grupos controle e veículo.

Uma revisão recente sobre biomarcadores de turnover ósseo e DM, concluiu através da análise de diversos estudos que o RANKL não difere no DM1, enquanto que a OPG pode estar reduzida nesta doença (Starup-Linde, 2013). A expressão de RANK, RANKL e OPG foi avaliada em modelo de fratura de tíbia em ratos diabéticos. A reação de imunohistoquímica mostrou que aos 7 dias houve menor quantidade de células positivas para estas proteínas no grupo diabético comparado ao controle. Entretanto a razão RANKL/OPG foi similar entre os grupos de estudo. Por outro lado, aos 14 dias, o número de células positivas para RANKL e OPG e a expressão do RNAm destes marcadores foi maior no grupo controle do que no grupo diabético. Neste período a razão RANKL/OPG no grupo diabético foi maior do que no grupo controle. Estes autores concluíram que houve um desequilíbrio na expressão de RANKL/OPG associado ao DM, resultado que contribuiu para atraso no processo de reparo da fratura óssea (Lima et al., 2013). Estes resultados corroboram com o estudo prévio em ratos diabéticos (Amorin et al., 2008) e com os dados da presente pesquisa, uma vez que também foi 
encontrado um desequilíbrio na relação RANKL/OPG durante os períodos de 3 e 10 dias e maior expressão de RANKL aos 7 dias de remodelação óssea.

Pacientes com DM1 foram avaliados em relação a densidade mineral, composição óssea e marcadores da remodelação óssea (Dayem et al., 2011). As concentrações séricas de OPG, OCC e procolágeno tipo 1 foram baixas nestes pacientes. Porém, foram encontradas altas concentrações de marcadores de reabsorção óssea como deoxipiridinolina urinária que reflete a atividade osteoclástica, comparado aos controles. Além disso, dos 47 pacientes diabéticos, 27 apresentavam osteopenia e 21 osteoporose. Este estudo concluiu que pacientes com DM1 tem baixa densidade mineral, reduzida formação óssea e grandes quantidades de marcadores de reabsorção óssea. Estes resultados suportam os resultados de baixas concentrações séricas de OCC, razão proteica reduzida de RANKL/OPG e altas concentrações de OPG nos pacientes diabéticos com periodontite (Lappin et al., 2009). Estes achados de formação e reabsorção óssea em pacientes diabéticos foram confirmados nos nossos achados histológicos, porém a sinalização molecular no presente estudo foi diferente. Provavelmente estas diferenças estejam presentes porque o nosso estudo foi desenvolvido em ratos com um prazo de 28 dias de evolução da doença e os métodos de avaliação molecular empregados foram diferentes.

O estudo sobre destruição periodontal em pacientes diabéticos tipo 1 mostrou que há uma relação positiva entre os níveis séricos de OPG, perda de inserção periodontal e severidade desta doença em diabéticos, sugerindo que este marcador é um importante indicador de destruição periodontal na DM1 (Antonoglou et al., 2013). Quando observamos a sinalização proteica de OPG também conseguimos observar que baixos níveis séricos desta proteína podem estar relacionados ao comprometimento na maturação óssea no grupo diabético.

$\mathrm{Na}$ avaliação microtomográfica em animais com periodontite, diabéticos ou não, foi observado uma reabsorção óssea progressiva ao longo do tempo. Entretanto este processo não foi associado a expressão gênica de Rankl e Opg. (Soboku et al. 2014), diferentemente do resultado molecular que observamos na razão proteica de RANKL/OPG aos 3 e 7 dias.

Por outro lado, foi possível detectar reduzida expressão gênica de Opg e razão gênica aumentada de Rankl/Opg nos dias 15 e 30 dias após 70 dias de experimento em ratos com diabetes e periodontite, isto é, houve um expressivo processo de osteoclastogênese. Além disso, observou-se que o DM1 isolado provocou destruição óssea alveolar, aumento no número de osteoclastos na região periapical e de furca e tais características estavam exacerbadas na periodontite. Ao analisar a quantidade proteica de RANKL e OPG, o DM afetou pouco a expressão de RANKL, mas diminuiu significativamente a quantidade de OPG comparado aos ratos não-diabéticos e estes resultados foram progressivamente reduzidos ao longo do tempo. (Silva et al., 2012). Desta maneira, observa-se que no DM as expressões 
destes marcadores da osteoclastogênese é muito variada com resultados muito diferentes na literatura em relação ao DM e o sistema RANK, RANKL e OPG (Motyl et al., 2009). Nota-se inclusive que as características exacerbadas na periodontite provavelmente estavam relacionadas a um processo inflamatório associado, como já observado em estudo prévio (Garlet et al., 2007). Entretanto, diversos autores (Garcia-Hernández et al., 2012; Xu et al., 2013) e o nosso trabalho também concordam que no DM há um comprometimento na formação óssea, devido às altas concentrações de glicose que levaria a um desequilíbrio nesta tríade.

Em relação a expressão gênica do grupo controle com disjunção $(\mathrm{Cd})$ aos 3 dias, pode-se observar que houve uma inibição da expressão gênica de Opn, Onc e Rankl comparado ao grupo diabetes com disjunção (Dd), mas que não foram diferentes do grupo controle (C). Por outro lado, a expressão proteica mostrou uma leve inibição de BMP2 e RANKL comparado ao grupo controle. Estes resultados possivelmente nos indicam que neste grupo há uma sinalização que parece comprometer o processo de formação óssea, apesar de haver inibição proteica de RANKL e alguns genes e proteínas não apresentarem alteração comparado aos demais grupos. Histologicamente neste período no terço anterior e médio, foi observado tecido sutural remanescente alterado, áreas inflamatórias, fibras colágenas desorganizadas e poucos vasos íntegros, ao passo que no terço posterior foi observada a presença de áreas hemorrágicas com um tecido um pouco mais organizado comparado aos dois terços anteriores. O tecido ósseo mostrou osteoclastos dentro das cavidades medulares próximas às bordas da sutura, além de osteoblastos e fibroblastos alterados, principalmente na região de terço médio da sutura. Estes achados do processo de remodelação inicial com presença de osteoclastos corroboram com o contexto molecular de comprometimento de formação óssea neste período.

Aos 7 dias, no grupo controle com disjunção foi observado uma inibição gênica de Bmp2 e Ibsp comparado ao grupo controle e grupo diabético com disjunção, respectivamente. Entretanto, houve um estímulo de Opn comparado ao grupo controle e grupo diabético com disjunção, além de um estímulo de Onc comparado ao grupo diabético com disjunção e um estímulo de Rankl comparado ao grupo controle. Estes dados de expressão gênica parecem mostrar um possível equilíbrio do processo de remodelação óssea, apesar de ter sido observado o estímulo reabsortivo de Rankl. Na expressão proteica, observou-se uma inibição de BMP2 comparado ao grupo controle $(C)$ e diabético com disjunção (Dd), porém houve um estímulo de BSP comparado ao grupo diabético com disjunção (Dd). Estes dados mostrados no grupo controle com disjunção não pareceram favorecer, tampouco comprometer, o processo de formação óssea. Além disso, a modulação da maioria das proteínas também não foi diferente comparado aos demais grupos analisados. Aos 10 dias, o grupo controle com disjunção mostrou uma inibição de Bmp2 comparado ao grupo controle e diabético com 
disjunção e uma inibição de Rankl comparado ao grupo diabético com disjunção. Houve estímulo de Opn, Onc e Occ, em relação ao grupo controle. Neste período é notável que a expressão gênica esta direcionada no intuito de favorecer o processo de formação óssea. Todos estes dados da expressão gênica estão em acordo com os resultados histológicos. Os demais genes não sofreram modulações significativas na suas expressões nos diferentes tempos de análise. Aos 10 dias o grupo controle com disjunção mostrou uma inibição proteica de BMP2 e RANKL comparado ao grupo controle, além de uma inibição de BSP comparado com o grupo diabético com disjunção e um estímulo proteico de OPG comparado aos grupos controle e diabético com disjunção. Assim neste período a osteoprotegerina pareceu evitar o processo de reabsorção óssea. Os dados histológicos mostraram grande processo de remodelação com o preenchimento da sutura com tecido ósseo neoformado, apesar deste processo não ter preenchido o espaço totalmente. No grupo controle com disjunção as outras proteínas não sofreram modulações significativas comparada aos demais grupos nos diferentes tempos de análise.

Nos tempos mais tardios de avaliação (7 e 10 dias) o padrão histológico foi semelhante. Foi possível observar áreas de proliferação vascular na região anterior e de terço médio da sutura, um processo inflamatório menos exacerbado, numerosos osteoclastos dentro das cavidades medulares caracterizando uma reabsorção óssea solapante e no terço posterior um tecido mais organizado com linha de neoformação óssea bem caracterizada. Além disso, no período mais tardio pode-se notar um cenário de grande atividade celular, com regiões em verdadeiro processo de reabsorção, porém apesar da formação óssea evidente, o tecido neoformado ainda não era suficiente para preencher todo o espaço da sutura aberta. Estes dados estão em acordo com os resultados moleculares que nos períodos mais tardios pareceu equilibrar a remodelação ou favorecer a formação óssea.

A remodelação óssea após ERM em ratos também foi avaliada previamente em diversos estudos (Sawada e Shimizu, 1996; Stuani 2008; Stuani, 2011, Pingueiro-Okada, 2012; Stuani 2012; Takenouchi et al., 2014). A análise histológica do grupo controle submetido à ERM do presente estudo corroborou com os resultados de trabalhos anteriores (Stuani 2008; Stuani, 2011, Stuani 2012). A formação óssea após ERM também foi avaliada através de micro-tomografia computadorizada com animais vivos e foi observado que o volume ósseo reduziu até $\mathrm{o} 12^{\circ} \mathrm{dia}$, posteriormente houve um aumento do volume ósseo entre os ossos palatinos até o dia 24, porém não suficiente para preencher todo o espaço da sutura Além disso, a expressão gênica do RNAm de Bmp2 após a RME também foi avaliada (Takenouchi et al., 2014). A expressão gênica de Bmp2 foi estimulada aos 3 dias comparada ao tempo zero de estudo. Por outro lado, a sua expressão foi reduzida nos períodos de 5 e 7 dias de avaliação de maneira tempo-dependente (Takenouchi et al., 2014). No presente estudo observou-se que a modulação gênica no grupo controle com disjunção não foi diferente 
estatisticamente comparado ao grupo controle. Ao longo do tempo também não se observou alterações na sua modulação. Assim, a ERM em nosso estudo não pareceu modular a expressão do gene Bmp2 nos tempos analisados.

Alguns autores mostraram um processo de osteopenia no osso dentoalveolar de ratos após a instalação de aparelho ortodôntico passivo (Vinoth et al., 2013). Este trabalho mostrou uma significante redução nos osteoblastos e na quantidade sérica de fosfatase alcalina aos 4 e 8 dias após instalação de uma mola helicoidal passiva no palato de ratos, mostrando uma redução da formação óssea. Além disso neste trabalho, houve um aumento dos marcadores de reabsorção aos 4 dias de estudo, sugerindo um aumento da reabsorção óssea, assim como um aumento histológico e histométrico da porosidade do osso interradicular dos ratos com o aparelho ortodôntico, mostrando claramente uma perda óssea nesta região. Estes autores concluíram que o aparelho ortodôntico poderia exercer efeitos indesejáveis no osso alveolar de suporte e ressaltaram a importância de reconhecer que forças ósseas podem ter efeitos negativos, assim como positivos na massa óssea (Vinoth et al., 2013). Tais resultados foram diferentes do presente estudo, uma vez que não observamos que o aparelho instalado provocou danos aos tecidos de suporte, apenas observamos que a força ortodôntica aplicada provocou um processo inflamatório associado à áreas de reabsorção, seguida de formação óssea tempo-dependente no grupo submetido à ERM.

Pode-se notar que no presente estudo a expressão proteica de BMP2 foi modulada em todos os grupos analisados durante o tempo. O pico de estímulo proteico de BMP2 foi aos sete dias de avaliação em todos os grupos analisados. Na análise imunohistoquímica realizada para avaliar a expressão de BMP2 (Takenouchi et al., 2014), encontrou-se também que a maior expressão desta proteína foi aos 7 dias no grupo com disjunção. Esta maior expressão foi localizada na linha de osteoblastos, nas células endoteliais dentro dos vasos sanguíneos e nos fibroblastos presentes na sutura palatina mediana submetida à ERM. Embora no presente estudo não tenha sido investigado qual tipo celular estava associado à expressão e síntese de BMP2, trabalhos futuros devem ser realizados com o objetivo de localizar áreas e células responsáveis pela maior produção de BMP2, principalmente nos animais diabéticos, submetidos ou não à ERM.

A expressão do RNAm de Ibsp foi avaliada durante movimentação ortodôntica em roedores. Nesse contexto foi possível observar que o dente sem tratamento ortodôntico (controle) apresentava uma movimentação fisiológica no sentido distal e os osteoblastos e osteócitos nesta região do septo interradicular apresentavam sinal positivo intenso para lbsp comparado com a superfície mesial do septo interradicular. No dente contralateral submetido à movimentação ortodôntica (mesialização) aos 3 dias, observou-se uma intensa sinalização de sialoproteína óssea na área de tração nos osteoblastos da região. Contudo aos 7 dias, já não havia mais sinalização gênica (Domon et al., 2001). No presente estudo, pode-se 
observar que a ERM influenciou a modulação gênica e proteica de lbsp nos períodos de 7 e 10 dias. No grupo controle com disjunção, houve uma inibição gênica de lbsp e um estímulo proteico comparado ao grupo diabético com disjunção. Novamente, observou-se que o padrão gênico não correspondeu ao observado na expressão proteica e provavelmente porque houve um acúmulo desta proteína ao longo do tempo no tecido ósseo no período de 7 dias. Além disso, aos 10 dias também se observou uma inibição desta proteína no grupo ERM comparado ao grupo controle. Neste período provavelmente ocorreu um maior processo reabsortivo que se sobrepôs ao acúmulo de BSP no tecido, visto que nos períodos finais histologicamente havia maior presença de áreas reabsortivas e com maior quantidade de osteoclastos.

O efeito da força compressiva na expressão gênica e proteica de BSP foi estudada em cultura de células osteoblásticas humanas. Neste trabalho foi observado elevada expressão gênica e proteica de BSP de maneira tempo-dependente (1 a 24 horas) (Mitsui et al., 2005). No presente estudo não foi possível observar o efeito da ERM na expressão gênica, apenas quando associada ao DM no tempo de 7 dias. Na expressão proteica nossos resultados também foram diferentes dos encontrados no estudo anterior, uma vez que não foi possível relacionar uma maior expressão de BSP nos grupos com ERM ao longo do tempo, apenas uma maior expressão no grupo controle com disjunção comparado ao grupo diabético com disjunção aos 7 dias, mostrando que a alteração sistêmica (DM) teve uma influência maior que a força ortodôntica aplicada. Estas diferenças de resultados provavelmente são devido ao modelo e metodologias de estudo diferentes.

Sabe-se que o estresse mecânico deforma a matriz óssea e gera um estímulo que leva ao processo de remodelação óssea. A OPN que está presente na matriz óssea é requerida para participar neste processo, uma vez que é necessária para a função (Terai et al., 1999; Fujihara et al., 2006; Chung et al., 2008) e aumento da sobrevivência dos osteoclastos (Tanabe et al., 2011), além de também reduzir a diferenciação, proliferação e quimiotaxia de osteoblastos e osteoclastos (Terai et al., 1999, Ishima et al., 2001; Ishima et al., 2007). No presente estudo foi observado uma inibição gênica de Opn aos 3 dias, estímulo gênico aos 7 dias e estímulo proteico aos 10 dias, mostrando desta maneira que a ostepontina é regulada em condições de estresse mecânico, porém de diferentes maneiras de acordo com o tempo de análise e o grupo de comparação.

A função e a regulação de osteopontina foram estudadas após estresse mecânico. No grupo controle foi possível detectar por hibridização in situ osteoblastos positivos no lado mesial das raízes do primeiro molar permanente (movimentação para mesial), porém poucos osteócitos positivos foram detectados nesta região. No período de 12 e 24 horas este mesmo padrão foi encontrado no grupo tratado ortodonticamente. No período de 48 horas após a movimentação ortodôntica houve um aumento na expressão de Opn nos osteócitos e osteoblastos no lado mesial. No período de 72 horas osteócitos e osteoblastos positivos para 
Opn alcançaram os valores máximos de expressão. No período mais tardio de 168 horas houve uma redução dos valores da expressão de Opn. No grupo controle havia poucos osteoclastos, enquanto que no grupo tratado havia grande quantidade destas células. Em camundongos knockout para Opn a remodelação óssea foi suprimida durante movimentação ortodôntica, uma vez que não foi detectada localização específica de osteoclastos nestes animais. Desta maneira, este estudo indicou uma função crítica deste gene no processo de remodelação óssea e mostrou a regulação desta proteína nas células osteoblásticas nos diferentes tempos de avaliação (Fujihara et al., 2006). Achados que corroboram com a presente pesquisa.

O estudo sobre a localização e a expressão de diversas proteínas osteogênicas também mostrou a presença de OPN na matriz óssea e na linha de reversão, sugerindo que esta proteína tivesse um papel durante o processo de reabsorção óssea (Roach 1994). Estes dados corroboram com o trabalho que mostrou a expressão gênica de OPN no processo de remodelação durante a movimentação dental fisiológica e a expressão de RNAm nas células da superfície de reabsorção (Takano-Yamamoto et al., 1994). No presente estudo parece que a osteopontina está envolvida com o processo de remodelação óssea, visto que no grupos com ERM há um processo reabsortivo, apesar da presença de áreas de formação óssea nos tempos mais tardios.

O estudo prévio sobre a expressão gênica e proteica de BSP e OPN durante à aplicação de força compressiva in vitro, apresentou um padrão bifásico de expressão gênica de Opn. O nível deste gene nas células comprimidas a $1 \mathrm{~g} / \mathrm{cm}^{2}$ foi aparentemente maior do que no grupo controle nos períodos iniciais (1h, 3h e $6 \mathrm{~h}$ ). Entretanto, foi menor que o controle nos períodos mais tardios de avaliação (9,12 e 24h). Por outro lado, a expressão proteica de OPN, foi elevada de maneira tempo-dependente até as 9 horas de avaliação e diminuiu drasticamente às 12 e $24 \mathrm{~h}$ após a aplicação da força compressiva quando comparado ao controle (Mitsui et al., 2005). Os resultados da expressão gênica e proteica de OPN deste trabalho in vitro foram diferentes dos perfis de expressão encontrados no presente trabalho. No período de 3 dias, período mais inicial de avaliação, não foi possível encontrar diferença na expressão gênica de Opn entre o grupo controle e controle com disjunção e nos tempos mais tardios da remodelação óssea, foi encontrado maior expressão gênica de Opn no grupo controle com disjunção comparado ao grupo controle. Além disso, não foi possível encontrar diferença entre os grupos controle e controle com disjunção nos diferentes tempos de análise. Tais diferenças provavelmente são devido ao estudo ser in vitro, ao tempo de análise e à quantidade e o tipo de força aplicada, pois na pesquisa in vitro a força aplicada foi de compressão, enquanto que no presente estudo in vivo foi aplicada força de tração.

A osteonectina participa no processo de remodelação durante a movimentação dental fisiológica (Takano-Yamamoto et al., 1994). Alguns autores avaliaram a expressão de 
genes osteogênicos durante a estimulação mecânica contínua em células mesenquimais e progenitoras humanas em culturas osteogênicas diferenciadas e indiferenciadas aos 7 e 14 dias de estudo. Neste estudo observaram que a estimulação mecânica aumentou a expressão de genes osteogênicos como colágeno, Onc, Opn, Bmp2 e Occ aos 7 e 14 dias. Além disso, a estimulação mecânica mostrou um aumento significante de cálcio depositado e de atividade de fosfatase alcalina (ALP) no grupo de células diferenciadas com estímulo mecânico aos 7 e 14 dias. Estes autores concluíram que o estímulo mecânico induziu o aumento da expressão de marcadores osteogênicos precoces e tardios em células diferenciadas osteogênicas (Lohberger et al., 2014). Estes resultados corroboram com o estudo prévio sobre avaliação da expressão gênica e proteica de ONC, integrina $\beta 5$ e colágeno durante a movimentação axial fisiológica de dentes de ratos. Este estudo mostrou uma maior regulação destes marcadores nos dentes com movimento axial pós-irruptivo comparado ao grupo controle (Luan et al., 2007). Tais resultados suportam a presente pesquisa que mostrou um maior estímulo de Onc aos 7 e 10 dias de avaliação, apesar das diferenças entre o tipo de estímulo aplicado e o tipo de estudo utilizado.

A osteocalcina tem participação no processo de remodelação durante a movimentação dental fisiológica (Takano-Yamamoto et al., 1994) e ortodôntica (Han et al., 2008; Alfaqeeh e Anil, 2011). Os níveis de OCC no fluido crevicular foram estudados durante remodelação óssea ativa após aplicação de forças ortodônticas em pacientes e pode-se observar que houve uma maior expressão desta proteína após 14 e 21 dias nos grupos tratados ortodonticamente (Alfaqeeh e Anil, 2011). O estudo em cães também observou expressão de OCC por imunohistoquímica nos grupos submetidos a movimentação ortodôntica nos tempos de 1, 2 e 4 semanas (Han et al., 2008). Por outro lado, a utilização de uma mola transpalatina inativa apoiada na superfície palatina de molares superiores de ratos não mostrou diferença nos níveis séricos de osteocalcina em ratos tratados e não tratados (Vinoth et al., 2013). No presente trabalho também não foi possível ver diferença entre o grupo controle com e sem disjunção em nenhum dos tempos avaliados, apenas houve diferença entre os grupos diabéticos com e sem disjunção no tempo de 3 dias. Além disso, observouse uma redução da expressão de OCC ao longo do tempo em alguns grupos de estudo. Desta maneira, ERM não pareceu afetar os níveis desta proteína nos diferentes tempos analisados, provavelmente porque a força de grande magnitude aplicada nos ratos tenha desempenhado um papel diferente ao observado quando se aplicou forças de pequena magnitude. Além disso, como a osteocalcina é considerada um marcador da atividade e função dos osteoblastos, um marcador tardio de osteoblastos diferenciados ou maduros (Tanaka et al., 2007) e marcador de formação óssea (Motyl et al., 2009). Provavelmente o tempo de 10 dias analisado, não tenha sido um tempo tardio o suficiente para se observar a regulação deste marcador, assim como não foi um tempo suficiente para formação óssea necessária para sua 
expressão molecular ser detectada.

A função do sistema RANK/RANKL/OPG na indução de remodelação óssea durante movimentação ortodôntica tem sido amplamente investigada por diversos autores, sugerindo que o equilíbrio entre RANKL e OPG no tecido periodontal é fator determinante para o processo de reabsorção óssea alveolar (Oshiro et al., 2002). Um estudo recente sobre a avaliação da remodelação óssea após ERM experimental e laserterapia de baixa potência (LBP) em ratos utilizando avaliações gênicas e proteicas, foi observado que o sistema RANK, RANKL e OPG estavam aumentados tanto no grupo com laser + ERM quanto no grupo sem laser + ERM comparado ao grupo controle sem ERM, principalmente nos períodos iniciais de avaliação, mostrando um estímulo desta tríade durante a ERM (Stuani, 2012).

No presente estudo aos 3 dias no grupo controle com disjunção houve uma inibição gênica de Rankl e proteica comparado aos grupos diabetes com disjunção e controle, respectivamente. Este mesmo padrão de sinalização foi observado aos 10 dias, além de ser observado um estímulo proteico de OPG comparado aos grupos controle e diabético com disjunção. Desta maneira nos períodos iniciais e tardios a regulação parece evitar o processo de osteoclastogênese, porém histologicamente a formação óssea ainda era escassa ao ponto de predominar o processo reabsortivo durante a remodelação nos períodos avaliados. Aos 7 dias houve um estímulo da expressão gênica de Rankl comparado ao grupo controle. Neste período notou-se que a ERM estimulou a reabsorção óssea. Quando se avaliou a relação gênica de Rankll Opg, observou-se aos 3 e 7 dias um estímulo para reabsorção óssea em todos os grupos submetidos à ERM quando comparado aos seus controles. Tais resultados também foram observados na histologia. Este resultado poderia sugerir que a movimentação dentária seria mais acentuada neste contexto. Contudo na razão proteica não foi observada modulação de RANKL/OPG, o que indica um equilíbrio da tríade, ou seja, processo de remodelação óssea ativo, porém até o tempo de 10 dias com predomínio do processo reabsortivo.

Um estudo de revisão da literatura observou que as concentrações de RANKL no fluido crevicular estavam aumentadas durante a movimentação ortodôntica, assim como a razão entre RANKL/OPG. Os estudos in vivo mostraram a presença de RANK e RANKL nos tecidos periodontais durante movimentação ortodôntica e os estudos in vitro sob estresse mecânico mostraram a indução de osteoclastogênese através da estimulação da expressão de RANKL. O RANKL é um ativador importante da reabsorção óssea via ativação de osteoclastos, ao passo que a OPG é uma proteína importante para ativação da formação óssea no lado de tração da movimentação ortodôntica. Desta maneira, concluíram que este sistema tem função importante na movimentação ortodôntica (Yamaguchi, 2009). Estudo semelhante foi realizado previamente avaliando estes marcadores no fluido crevicular de adolescentes e mostraram maiores expressões de RANKL e pequenas expressões de OPG 
nos dentes $24 \mathrm{~h}$ de força ortodôntica. Esta pesquisa foi refeita in vitro e o mesmo padrão foi encontrado dependente do tempo e da magnitude da força aplicada (Nishima et al., 2006). Estes resultados também foram observados nas concentrações salivares de RANKL e OPG e na razão RANKL/OPG durante movimentação ortodôntica em pacientes, porém observaram flutuações deste marcadores na saliva em diferentes fases da terapia ortodôntica (FlórezMoreno e tal., 2013). Estes resultados corroboram com o estudo que avaliou a quantidade de RANKL e OPG no fluido crevicular ao redor de mini-implantes submetidos à carga. $A$ quantidade de RANKL encontrada após carga foi maior em todos os tempos de avaliação (24h, 48h, 168h e 30 dias) do que previamente a instalação de carga nos mini-implantes de pacientes. Embora a concentração de OPG não tenha sido diferente entre os grupos, a relação OPG/RANKL foi menor no grupo submetido à carga. Neste trabalho os autores concluíram que os níveis de OPG e RANKL foram diferentes nos mini-implantes submetidos ou não à carga, devido à aplicação de força (Enhos et al., 2013).

Todos estes trabalhos corroboram com a expressão gênica no período de 3 e 7 dias do presente estudo, apesar de não ter sido observado a mesma razão proteica, provavelmente devido ao controle pós-transcricional, traducional, controle da degradação do RNAm e/ ou controle da atividade proteica de RANKL e OPG. Porém esta remodelação óssea parecendo equilibrada com presença de reabosrção óssea solapante, pode ser devido ao estímulo de citocinas pro-inflamatorias neste grupo, visto que no gap sutural, havia uma região com processo inflamatório exacerbado e numerosos osteoclastos. Esta hipótese é suportada pelo trabalho que avaliou o padrão da expressão de RNAm de diversas citocinas pró e antiinflamatórias em relação a diversos marcadores de remodelação óssea e da matriz extracelular no ligamento periodontal de pacientes submetidos à ERM em comparação com dentes saudáveis não tratados ortodonticamente (Garlet et al., 2007). Estes autores observaram que no lado de compressão houve maior expressão de fator de necrose tumoral alfa (Tnfa), Rankl e metaloproteinase da matriz 1 (MMP-1), enquanto que no lado de tração houve maior expressão de interleucina-10, Timp-1 (inibidor tecidual de MMP-1), Col-I (colágeno 1), Opg e Occ. Estes resultados mostraram que foi possível encontrar expressões diferentes de citocinas pró e anti-inflamtorias, assim como de marcadores da osteoclastogênese durante o movimento ortodôntico.

A expressão de OPG e RANKL foi estudada recentemente na reabsorção de raiz durante movimentos ortodônticos de grande magnitude em ratos (Zhou e tal., 2011). Este estudo observou que as condições de reabsorção severa estavam presentes no lado de pressão da raiz mesial do primeiro molar superior aos 8 e 12 dias, assim como o número de odontoclastos. A expressão de RNAm de Opg foi maior no lado de tração e de Rankl no lado de pressão. Os níveis de Rankl foram significativamente elevados nos dias 4, 8 e 12. Além disso, a relação Rankl/Opg foi maior no lado de pressão e reduzida no lado de tração. Os 
autores concluíram que as mudanças na expressão de RNAm de Rankl e na relação Rankl/Opg foram acompanhadas pela alteração de odontoclastos na raiz reabsorvida, sugerindo um envolvimento importante destes marcadores no processo de reabsorção dental. Tais resultados corroboram com estudo prévio que observou que células do ligamento periodontal obtidas de tecidos com severa reabsorção apical externa de raiz pode produzir grandes quantidades de RANKL e desta maneira estimular a osteoclastogênese (Yamaguchi et al., 2006). Estes trabalhos suportam o presente estudo, apesar do processo de osteoclastogênese estar acentuado histologicamente numa área de força de tração de grande magnitude.

A expressão gênica do grupo diabético submetido à disjunção aos 3 dias mostrou uma inibição de Bsp, Occ, Rank e Opg comparado ao grupo diabético, um estímulo de Opn e Onc comparado ao grupo controle com disjunção e um estímulo de Rankl comparado aos grupos controle com disjunção e diabético. Estes resultados gênicos mostram que a associação de diabetes e ERM favoreceu o processo de reabsorção óssea e comprometeu o processo de formação óssea comparada ao grupo diabético. Por outro lado, a sinalização ocorreu no sentido de estimular a formação óssea comparado ao grupo controle com ERM. A expressão proteica aos 3 dias no grupo diabetes com disjunção mostrou uma inibição de BMP2 comparado ao grupo diabetes, um estímulo de OCC e OPG comparado ao grupo diabetes. Neste contexto o perfil da expressão gênica não foi observado na expressão proteica, uma vez que pode-se observar uma proteção contra o processo de reabsorção óssea no grupo diabetes com disjunção quando comparado ao grupo diabetes, isto é, pareceu haver um processo para evitar a osteoclastogênese e favorecer a osteogênese. Estes achados não foram observados na histologia, uma vez que no grupo DM + ERM havia mais atividade osteoclástica, caracterizando reabsorção óssea solapante, quando comparado ao grupo DM. Histologicamente aos 3 dias ainda não era possível observar processo de formação óssea neste grupo comparado ao grupo controle com disjunção.

Aos 7 dias no grupo diabetes com disjunção houve um estímulo gênico de Bsp comparado aos grupos diabetes e controle com disjunção, assim como um estímulo de Rankl comparado ao grupo diabetes. Por outro lado, houve uma inibição de Opn e Onc comparado ao grupo controle com disjunção. Desta maneira, neste período a expressão gênica no grupo diabetes com disjunção pareceu tentar estimular a formação óssea, porém a expressão gênica de Rankl pareceu estimular o processo reabsortivo quando comparado ao grupo diabetes. Quando comparou-se diabetes com disjunção ao grupo controle com disjunção, observou-se um processo que parecia comprometer a formação óssea. Na histologia observou-se maior presença de osteoclastogênese no grupo diabético comparado aos grupos diabetes e controle com disjunção. Aos 7 dias, neste grupo houve um leve estímulo proteico de BMP2 comparado ao grupo controle com disjunção e uma inibição de BMP2 e BSP 
comparado aos grupos diabetes e controle com disjunção, respectivamente. Além disso, foi observado uma inibição de RANKL comparado ao grupo diabetes. Baseado na modulação destas proteínas no período de 7 dias, é provável que o grupo diabetes com disjunção comparado ao grupo controle com disjunção esteja havendo uma equilíbrio no processo de remodelação óssea neste grupo. Ao passo que quando comparamos ao grupo diabético observamos um redução na formação óssea devido aos valores de BMP2, mas um processo que parecia evitar a reabsorção com os valores obtidos de RANKL. Porém na histologia neste grupo podemos observar um nítido processo reabsortivo nestes tempos de avaliação comparado ao grupo diabético e controle com disjunção.

Aos 10 dias no grupo diabetes com disjunção foi observado um estímulo da expressão de Bmp2 e Rankl comparado aos grupos diabético e controle com disjunção, uma inibição de Bsp comparado ao grupo diabetes. Neste período o DM associado ao ERM pareceu promover o processo de reabsorção óssea comparado aos grupos DM e ao grupo controle com disjunção. Na histologia o que se pode observar foi um cenário com presença de osso imaturo, porém em menor quantidade do que no grupo controle com disjunção e ainda assim, dentro de um contexto mais direcionado para o processo de reabsorção óssea. Os demais genes no grupo diabetes com disjunção não sofreram modulações significativas comparada aos outros grupos nos diferentes tempos de análise. Aos 10 dias no grupo diabetes com disjunção, houve uma inibição proteica de BMP2 e OPG quando comparado aos grupos diabetes e controle com disjunção, respectivamente e um estímulo de BSP comparado ao grupo controle com disjunção. Neste contexto a associação de DM com ERM pareceu prejudicar o processo de formação óssea quando comparado ao grupo diabetes sem ERM e não evitar o processo reabsortivo quando comparado ao grupo controle com disjunção. As demais proteínas no grupo diabetes com disjunção não sofreram modulações significativas comparada aos outros grupos nos diferentes tempos de análise. Histologicamente, pode-se observar um comprometimento da formação óssea com presença de intensa atividade de reabsorção óssea solapante no período de 10 dias, que corrobora com os dados moleculares.

Quando se avaliou a relação gênica de Rankll Opg, observou-se aos 3, 7 e 10 dias um estímulo para reabsorção óssea nos grupos diabéticos submetidos à ERM quando comparado ao grupo diabético, porém este padrão se repetiu apenas aos 3 e 10 dias quando comprado ao grupo controle com disjunção. Tais resultados também foram observados na histologia. Na histologia o que se notou foi um processo de reabsorção acentuado no grupo diabetes com disjunção comparado aos demais grupos. Na relação proteica de RANKL/ OPG não foi observado estimulação para a reabsorção óssea no grupo diabetes com disjunção em nenhum tempo de avaliação. Estes achados proteicos no grupo diabetes com disjunção não corroboram com os resultados da análise histológica. Esta diferença que existe entre a razão gênica e proteica de RANKL/OPG pode ser provavelmente devido ao controle pós-transcrição 
e pós-tradução, além da presença de proteínas pro e anti-inflamatórias presentes no DM e no gap da ERM, que contribuíram para um tecido com processo reabsortivo e inflamatório nos diferentes períodos.

Visto que a expressão gênica e proteica foram diferentes em todos os tempos analisados, pode-se sugerir que está havendo modulação de outros genes ou proteínas como citocinas pró e anti-inflamatórias, que afetam o metabolismo ósseo (Garlet et al., 2007; Braga et al., 2011). Desta, maneira há necessidade de futuras investigações relacionadas a estes marcadores, a fim de esclarecer e entender a modulação neste grupo DM associado ao ERM.

Sabe-se que a alteração no estado metabólico interfere com o processo de remodelação, podendo resultar em diferentes taxas de movimentação ortodôntica. O turnover ósseo foi avaliado utilizando ratos com movimentação ortodôntica associado ao baixo e alto metabolismo ósseo induzido farmacologicamente comparado aos ratos sem tratamento ortodôntico. O turnover ósseo em ratos influenciou a taxa e o tipo de movimento ortodôntico e desta maneira deveria ser levado em consideração quando do planejamento ortodôntico em pacientes com o metabolismo ósseo alterado ou com doença metabólicas ou em pacientes com uso crônico de medicação que influencia no metabolismo ósseo (Verna, Dalstra, Mesel, 2000). Conclui-se, portanto, que são necessárias pesquisas para o entendimento de como doenças sistêmicas afetam o metabolismo ósseo durante a aplicação de forças ortodônticas.

A distração osteogênica em fêmur de ratos como modelo de estudo da osteogênese e regeneração óssea em ratos diabético-induzidos mostrou que que radiograficamente e histologicamente houve uma redução significante no total de formação óssea nos ratos diabetes-induzidos quando comparado aos ratos controle (Fowkles et al., 2008). Este estudo ainda avaliou a relação entre formação óssea e composição da medula óssea durante o processo de neoformação óssea e os resultados sugeriram que as células mesenquimais indiferenciadas estavam sendo levadas mais em direção a linhagem de adipócitos, assim possivelmente reduzindo a quantidade de osteoblastos precursores disponíveis para gerar novo osso no gap de distração. Resultados similares foram observados em pesquisa prévia utilizando forças ortodônticas em maxila (Villarino et al., 2011), apesar, do osso longo de tíbia ser diferente estruturalmente do osso maxilar e poder apresentar um padrão de formação óssea distinto. Neste trabalho prévio foi utilizado técnicas histológicas de análise para avaliar em ratos os efeitos do DM no longo prazo associado à movimentação dentária utilizando forças de grande magnitude. Neste contexto os autores, observaram redução da formação óssea em ratos diabéticos e sugeriram que pacientes diabéticos não monitorados não deveriam receber tratamento ortodôntico, mesmo quando necessário, até restabelecerem o estado de normoglicemia, uma vez que a aplicação de forças ortodônticas pesadas poderiam causar efeitos indesejáveis (Villarino et al., 2011). Estes resultados corroboram com os resultados histomorfológicos recentes e histológicos que indicaram um processo de 
remodelação óssea prejudicada em ratos diabéticos submetidos à movimentação dentária (Maia et al., 2014). Em conjunto, estes trabalhos suportam os resultados da presente pesquisa, visto que observamos no grupo diabético submetido à ERM uma maior osteoclastogênese e uma menor osteogênese que refletiu num comprometimento da formação óssea associado à um processo de reabsorção intenso a curto e médio prazo.

Um estudo prévio relatou que a DM poderia potencializar a doença periodontal e acelerar o processo de reabsorção óssea. Os autores relataram neste trabalho que a doença periodontal estava associada à perda da expressão compensatória de OPG no DM1 e correlacionou a destruição óssea alveolar ao processo de osteoclastogênese (Silva et al., 2012). Este estudo suporta a assertiva de que associar o DM a algum outro fator de remodelação como a ERM ou a periodontite, estimula e intensifica o efeito reabsortivo, isto é, o DM associado a inflamação pode potencializar o processo de reabsorção óssea, prejudicando o processo de remodelação óssea. No presente estudo observamos na expressão gênica um aumento da atividade osteoclástica e reduzida osteogênese aos 3 dias de estudo. Este padrão se manteve histologicamente e corrobora com o trabalho que relatou uma menor expressão gênica de marcadores osteoblásticos em ratos diabéticos submetidos à movimentação ortodôntica (Braga et al., 2011). Este estudo avaliou os efeitos do DM1 no recrutamento, na atividade de osteoclastos, assim como os efeitos do DM1 nos marcadores de osteoblastos e na movimentação ortodôntica em camundongos. Foi observado que no tecido periodontal dos animais diabéticos houve maior expressão de RNAm de fatores osteoclásticos para Rankl e fator estimulador de colônia 1 (Csf1) comparado ao grupo controle 72 horas após a movimentação ortodôntica. Estes resultados também foram observados para o RNAm de algumas citocinas pró-inflamatórias no grupo diabético 12 e 72 horas após a movimentação ortodôntica. Ao passo que a expressão de RNAm de marcadores osteoblásticos como Alp, Col1 , Runx2 e Occ foi menor no grupo diabético do que no grupo controle no mesmo período avaliado. Estes autores concluíram que a movimentação ortodôntica foi maior em camundongo diabéticos e observaram que este fenótipo foi revertido com insulinoterapia. Estes resultados indicam que a diminuição na diferenciação de osteoblastos no DM levou a uma redução da sinalização inibitória nos osteoclastos, o que resultaria em maior reabsorção alveolar e movimentação ortodôntica. Assim, o DM1 descontrolado alterou o turnover ósseo devido ao desequilíbrio da função osteoclasto/ osteoblasto e ao aumento dos níveis de mediadores pró-inflamatórios, levando ao aumento da reabsorção óssea e maior quantidade de movimentação ortodôntica (Braga et al., 2011).

Os achados destes estudos prévios corroboram com os resultados do presente trabalho no que tange sobre a associação de DM e ERM na expressão de Occ, visto que o grupo diabético com disjunção apresentou reduzida sinalização comparado ao grupo diabético aos 3 dias de avaliação. Observou-se também um estímulo de Occ no grupo controle com 
disjunção aos 10 dias comparado ao grupo controle, o que sugere-se que a ERM parece ter influência em tempos tardios na expressão gênica de Occ, porém não foi influenciada pela DM neste período. Além disso, o estudo anterior (Braga et al., 2011) corrobora com os nossos resultados, haja vista que encontramos maior expressão gênica de marcadores da osteoclastogênese como Rankl e menor expressão de alguns marcadores osteoblásticos em animais diabéticos submetidos à movimentação ortodôntica durante os períodos de análise. No presente trabalho a razão gênica de Rankl/ Opg no grupo diabético com disjunção mostrou um estímulo para reabsorção comparada ao grupo diabético em todos os tempos analisados, assim como este mesmo perfil foi encontrado nos tempos de 3 e 10 dias quando comparado ao grupo controle com disjunção. Em Ortodontia, a administração local de osteoprotegerina visando a inibição da osteoclastogênese reduziu a recidiva após o tratamento (Zhao et al., 2012). Estudo recente in vivo utilizando camundongos (Taddei et al., 2012) suportam os achados prévios e os da presente pesquisa.

Diversos autores analisaram a expressão de proteínas no osso alveolar durante movimentação dentária ortodôntica de ratos saudáveis e ratos diabéticos-induzidos (Li et al., 2010; Zhang, Li, Bi, 2011). Um estudo recente indicou que em ratos diabéticos há maior produção de MMP-1 e menor produção de Col-I e TIMP-1. Observaram que nos ratos saudáveis as fibras colágenas estavam orientadas e os capilares estavam saudáveis antes do tratamento ortodôntico (dia zero). Após a movimentação houve maior desorganização das fibras colágenas e colapso dos capilares nos dias 1 a 7 . Nos dias 10 e 14 estas estruturas estavam normais. No grupo DM as fibras colágenas estavam orientadas irregularmente e os capilares estavam distendidos nos animais submetidos ou não ao tratamento ortodôntico. Desta maneira, observaram que o DM afetou algumas proteínas envolvidas no processo de remodelação do ligamento periodontal (LP) durante a pressão mecânica, além de prolongar a duração da degradação e da remodelação do ligamento periodontal, assim como o processo de reabsorção do osso alveolar (Zhang, $\mathrm{Li}, \mathrm{Bi}, 2011)$. Estes achados corroboram com o estudo prévio que também mostrou maiores produções de MMP-1 e Col-III e diminuição da expressão de Col-I no ligamento periodontal de ratos diabéticos, além de observarem uma ação atrasada dos osteoclastos após a indução ortodôntica. Histologicamente detectaram que o estresse ortodôntico estimulou a osteoclastogênese e formação de lacunas de Howship nos grupos com e sem DM. Além disso, o número de osteoclastos em ambos os grupos foi marcadamente aumentado, mostrando assim, que os animais diabéticos apresentaram uma recuperação prejudicada pelo dano causado pelo estresse ortodôntico e que os eventos de remodelação estavam alterados nos ratos com DM, prolongando a duração da degradação, remodelação do ligamento periodontal e reabsorção do osso alveolar. Extrapolando estes achados para o consultório odontológico, estes autores sugeriram que o curso do tratamento ortodôntico seria mais prolongado em pacientes diabéticos, visto que são mais susceptíveis aos estresse 
induzido que danifica o tecido do que em pacientes normoglicêmicos (Li et al., 2010). Desta maneira, estes resultados estão em acordo e suportam a presente pesquisa, visto que associando DM e ERM, foi possível observar um prejuízo maior no processo de remodelação óssea. Além disso, concordamos que a glicemia deve ser restaurada em níveis de normalidade, a fim de assegurar um tratamento ortodôntico correto sem intercorrências devido a presença de fatores que alteram o metabolismo ósseo.

Portanto, estes resultados mostraram diferentes sinalizações gênicas e proteicas nos diferentes grupos e tempos de avaliação, cujos resultados corroboraram com os achados histológicos. Entretanto, a ausência de regulação de alguns genes e proteínas estudados na presente pesquisa merecem futuras investigações. 


\section{Conclusão}




\section{CONCLUSÃO}

A partir do presente estudo pode-se concluir que:

1) O diabetes melitus alterou a expressão gênica e proteica dos diferentes biomarcadores do processo de remodelação óssea após expansão rápida da maxila, resultando no comprometimento do processo de reparo ósseo. Especificamente foi observado um estímulo à osteoclastogênese e inibição dos marcadores de osteogênese durante todos os períodos avaliados. A associação entre os dois fatores de estudo, diabetes e expansão rápida da maxila, pareceu ter contribuído para o atraso no reparo ósseo.

2) Isoladamente, em animais com diabetes melitus sem expansão rápida da maxila, o padrão de expressão dos genes e proteínas que regulam o catabolismo e anabolismo ósseo foi alterado, resultando histologicamente em um atraso na remodelação óssea fisiológica.

3) A expansão rápida da maxila modulou os diferentes genes e proteínas avaliados, num contexto de intensa remodelação óssea, caracterizada por formação de um tecido desorganizado na região da sutura palatina mediana, com intensas áreas inflamatórias, hemorrágicas e reabsortivas. Contudo, até o período de 10 dias pós abertura da sutura, não foi possível observar o completo preenchimento do gap sutural por tecido ósseo.

Assim, os achados histológicos somado à investigação molecular das vias de sinalização osteogênicas mostraram que o diabetes melitus associado ou não à expansão rápida da maxila prejudicou o processo de reparo ósseo nos diferentes tempos analisados. 


\section{OReferências}




\section{REFERÊNCIAS*}

Abbassy MA, Watari I, Soma K. Effect of experimental diabetes on craniofacial growth in rats. Arch Oral Biol. 2008;53:819-25.

Alberts B, Johnson A, Lewis J, Raff M, Roberts K, Walter P. Molecular biology of the cell. $5^{\text {a }}$ ed. Nova York: Garland Science, 2008.

Alexopoulou O, Jamart J, Devogelaer JP, Brichard S, de Nayer P, Buysschaert M. Bone density and markers of bone remodeling in type 1 male diabetic patients. Diabetes Metab. 2006 Nov;32:453-8.

Alfaqeeh SA, Anil S. Osteocalcin and N-telopeptides of type I collagen marker levels in gingival crevicular fluid during different stages of orthodontic tooth movement. Am J Orthod Dentofacial Orthop. 2011;139:e553-9.

Al-Yaarubi S, Ullah I, Sharef SW, Al Shidhani A, Al Hanai S, Al Kalbani R, Al Jamoodi S. Demographic and clinical characteristics of type 1 diabetes mellitus in omani children - single center experience. Oman Med J. 2014;29:119-22.

American Diabetes Association. Standards of medical care in Diabetes - 2011. Diabetes Care. 2011;34 (Suppl1):S11-S61.

American Diabetes Association. Standards of Medical Care in Diabetes - 2014. Diabetes Care. 2011;37 (Suppl1):S14-S79.

Amos AF, McCarty DJ, Zimmet P. The rising global burden of diabetes and its complications: estimates and projections to the year 2010. Diabet Med. 1997;14 (Suppl 5):S1-S85.

Antonoglou G, Knuuttila M, Nieminen P, Vainio O, Hiltunen L, Raunio T, et al. Serum osteoprotegerin and periodontal destruction in subjects with type 1 diabetes mellitus. J Clin Periodontol. 2013;40(8):765-70.

Bishara SE, Ortho D, Stanley RN. Maxillary expansion: clinical implications. Am J Orthod Dentofac Othorp. 1987;91:3-14.

\footnotetext{
* Normas internas do Programa de Pós-Graduação em Odontopediatria da FORP-USP (2009), de acordo com o International Comiitte of Medicals Journals Editors. Uniform Requirements for manuscripts submitted to Medical Journal, 1997. Disponível em http//www.mja.com.au/public/informatiom.html. Acesso em 03/07/2014.
} 
Blondel 0 , Bailbe D, Portha B. Relation of insulin deficiency to impaired insulin action in NIDDM adult rats given streptozotocin as neonates. Diabetes. 1989, 38:610-617.

Botolin S, McCabe LR. Chronic hiperglycemia modulates osteoblast gene expression through osmotic and non-osmotic pathways. J Cell Biochem. 2006;99:411-24.

Botolin S, Faugere MC, Malluche H, Orth M, Meyer R, Mccabe LR. Increased bone adiposity and peroxisomal proliferator- activated receptor-2 expression in type I diabetic mice. Endocrinology. 2005;146:3622-3631.

Braga SM, Taddei SR, Andrade I Jr, Queiroz-Junior CM, Garlet GP, Repeke CE, Teixeira MM, da Silva TA. Effect of diabetes on orthodontic tooth movement in a mouse model. Eur J Oral Sci. 2011;119:7-14.

Brekken RA, Sage EH. SPARC, a matricellular protein: at the crossroads of cell-matrix communication. Matrix Biol. 2001;19:816-27.

Camozzi V, Tossi A, Simoni E, Pagani F, Francucci CM, Moro L. Role of biochemical markers of bone remodeling in clinical practice. J Endocrinol Invest. 2007, 30(Suppl6):S13-S17.

Carreira AC, Lojudice FH, Halcsik E, Navarro RD, Sogayar MC, Granjeiro JM. Bone morphogenetic proteins: facts, challenges, and future perspectives. J Dent Res. 2014;93:33545.

Carvalho AC, Paiva SM, Viegas CM, Scarpelli AC, Ferreira FM, Pordeus IA. Impact of malocclusion on oral health-related quality of life among Brazilian preschool children: a population-based study. Braz Dent J. 2013;24:655-61.

Chang PC, Chung MC, Wang YP, Chien LY, Lim JC, Liang K, et al. Patterns of diabetic periodontal wound repair: a study using micro-computed tomography and immunohistochemistry. J Periodontol. 2012;83:644-52.

Chung JW, Kim MS, Piao ZH, Jeong M ,Yoon SR, Shin N, Kim SY, Hwang ES, Yang Y, Lee $\mathrm{SH}$, Kim YS, Choi I. Osteopontin promotes the development of natural killer cells from hematopoietic stem cells. STEM CELLS. 2008;26:2114-23. 
Cintra LT, Samuel RO, Facundo AC, Prieto AK, Sumida DH, Bomfim SR, et al. Relationships between oral infections and blood glucose concentrations or HbA1c levels in normal and diabetic rats. Int Endod J. 2014;47:228-37.

Coe LM, Zhang J, McCabe LR. Both spontaneous Ins2(+/-) and streptozotocin-induced type I diabetes cause bone loss in young mice. J Cell Physiol. 2013 ;228:689-95.

Cox G, Einhorn TA, Tzioupis C, Giannoudis PV. Bone turnover markers in fracture healing. J Bone Joint Surg Br. 2010,92-B:329-334.

Cross DL, Mcdonald JP. Effect of rapid maxillary expansion on skeletal, dental, and nasal structures: a postero-anterior cephalometric study. Eur J Orthod. 2000;22:519-528.

da Silva AP, Petri AD, Crippa GE, Stuani AS, Stuani AS, Rosa AL, Stuani MB. Effect of lowlevel laser therapy after rapid maxillary expansion on proliferation and differentiation of osteoblastic cells. Lasers Med Sci. 2012 Jul;27(4):777-83.

Danaei G, Finucane MM, Lu Y, Singh GM, Cowan MJ, Paciorek CJ, et al. National, regional, and global trends in fasting plasma glucose and diabetes prevalence since 1980: systematic analysis of health examination surveys and epidemiological studies with 370 country-years and 2.7 million participants. Lancet. 2011;378:31-40.

Davidovitch Z, Nicolay OF, Ngan PW, Shanfeld JL. Neurotransmitters, cytokines and the control of alveolar bone remodeling in orthodontics. Dent Clin North Am. 1988;32:411-35.

Davidovitch Z. Tooth movement. Crit Rev Oral Biol Med. 1991;2:411-50.

Dayem SMAE, El-Shehaby AM, Abd El Gafar A, Fawzy A, Salama H. Bone density, body composition, and markers of bone remodeling in type 1 diabetic patients. Scand J Clin Lab Invest. 2011;71:387-93.

de Amorim FP, Ornelas SS, Diniz SF, Batista AC, da Silva TA. Imbalance of RANK, RANKL and OPG expression during tibial fracture repair in diabetic rats. J Mol Histol. 2008;39:401-8.

Denhardt DT, Noda M. Osteopontin expression and function: role in bone remodeling. J Cell Biochem. Suppl 1998;30-31:92-102. 
Dienelt A, zur Nieden NI. Hyperglycemia impairs skeletogenesis from embryonic stem cells by affecting osteoblast and osteoclast differentiation. Stem Cells Dev. 2011;20:465-74.

Domon S, Shimokawa H, Yamaguchi S, Soma K. Temporal and spatial mRNA expression of bone sialoprotein and type I collagen during rodent tooth movement. Eur $\mathrm{J}$ Orthod. 2001;23:339-48.

Du S, Wu H, Xu X, Meng Y, Xia F, Zhai H, Lu Y. Tracing fasting glucose fluxes with unstressed catheter approach in streptozotocin induced diabetic rats. J Diabetes Res. 2014;2014:1-7.

El-Bialy T, Aboul-Azm SF, El-Sakhawy M. Study of craniofacial morphology and skeletal maturation in juvenile diabetics (type I). Am J Orthod Dentofacial Orthop. 2000;118:189-95.

El H, Palomo JM. Three-dimensional evaluation of upper airway following rapid maxillary expansion. Angle Orthod. 2014;2:265-73.

Enhos S, Veli I, Cakmak O, Ucar FI, Alkan A, Uysal T. OPG and RANKL levels around miniscrew implants during orthodontic tooth movement. Am J Orthod Dentofacial Orthop. 2013;144:203-9.

Flórez-Moreno GA, Isaza-Guzmán DM, Tobón-Arroyave SI. Time-related changes in salivary levels of the osteotropic factors SRANKL and OPG through orthodontic tooth movement. Am J Orthod Dentofacial Orthop. 2013;143:92-100.

Fowlkes JL, Bunn RC, Liu L, Wahl EC, Coleman HN, Cockrell GE, Perrien DS, Lumpkin CK, Thrailkill KM. Runt-related transcription factor 2 (RUNX2) and RUNX2-related osteogenic genes are downregulated throughout osteogenesis in type 1 diabetes mellitus. Encocrinology. 2008;149:1697-1704.

Freitas, HS, Shaan BD, Silva RB, Okamoto MM, Oliveira-Souza M, Machado UF. Insulin but not phlorizin treatment induces a transient increase in GLUT2 gene expression in the kidney of diabetic rats. Nephron Physiol. 2007;105:42-51.

Fujihara S, Yokozeki M, Oba Y, Higashibata Y, Nomura S, Moriyama K, Function and regulation of osteopontin in response to mechanical stress. J Bone Mineral Res. 2006;21:95664. 
García-Hernández A, Arzate H, Gil-Chavarría I, Rojo R, Moreno-Fierros L. High glucose concentrations alter the biomineralization process in human osteoblastic cells. Bone. 2012;50:276-88.

Garlet TP, Coelho U, Silva JS, Garlet GP. Cytokine expression pattern in compression and tension sides of the periodontal ligament during orthodontic tooth movement in humans. Eur $\mathrm{J}$ Oral Sci. 2007;115:355-62.

Gerstenfeld LC, Cullinane DM, Barnes GL, Graves DT, Einhorn TA. Fracture healing as a postnatal developmental process: molecular, spatial, and temporal aspects of its regulation. $\mathrm{J}$ Cell Biochem. 2003;88:873-84.

Giglio MJ, Lama MA. Effect of experimental diabetes on mandibular growth in rats. Eur J Oral Sci. 2001;109:193-7.

Guyton AC, Hall JE. Tratado de Fisiologia Médica, $10^{\text {a }}$ ed. Rio de Janeiro: Guanabara Koogan, 2002, cap. 78, p.827-840.

Haas AJ. Rapid expansion of the maxillary dental arch and nasal cavity by opening the midpalatal suture. Angle Ortho. 1961;31:2073-90.

Haas AJ. The treatment of maxillary deficiency by opening the midpalatal suture. Angle Ortho. 1965;35:200-217.

Haas AJ. Long term posttreatment evaluation of rapid palatal expansion. Angle Ortho. 1980;50:189-217.

Hamann C, Goettsch C, Mettelsiefen J, Henkenjohann V, Rauner M, Hempel U,Bernhardt R, Fratzl-Zelman N, Roschger P, Rammelt S, Günther KP, Hofbauer LC. Delayed bone regeneration and low bone mass in a rat model of insulin-resistant type 2 diabetes mellitus is due to impaired osteoblast function. Am J Physiol Endocrinol Metab. 2011;301:E1220-8.

Han XL, Meng Y, Kang N, Lv T, Bai D. Expression of osteocalcin during surgically assisted rapid orthodontic tooth movement in beagle dogs. J Oral Maxillofac Surg. 2008;66:2467-75.

Harries LW, McCulloch LJ, Holley JE, Rawling TJ, Welters HJ, Kos K. A role for SPARC in the moderation of human insulin secretion. PLoS One. 2013;8:e68253. 
Haug AT, Braun KF, Ehnert S, Mayer L, Stöckle U, Nüssler AK, Pscherer S, Freude T. Gene expression changes in cancellous bone of type 2 diabetics: a biomolecular basis for diabetic bone disease. Langenbecks Arch Surg. 2014;399:639-47.

He H, Liu R, Desta T, Leone C, Gerstenfeld LC, Graves DT. Diabetes causes decreased osteoclastogenesis, reduced bone formation, and enhanced apoptosis of osteoblastic cells in bacteria stimulated bone loss. Endocrinology. 2004;145(1):447-52.

Heguy A, O'Connor TP, Luettich K, Worgall S, Cieciuch A, Harvey BG, et al. Gene expression profiling of human alveolar macrophages of phenotypically normal smokers and nonsmokers reveals a previously unrecognized subset of genes modulated by cigarette smoking. $\mathrm{J}$ Mol Med. 2006;84:318-28.

Hie M, Shimono M, Fuji K, Tsukamoto I. Increased cathepsin K and tartrate-resistant acid phosphatase expression in bone of streptozotocin-induced diabetic rats. Bone 2007;41:10451050.

Hie M, litsuka N, Otsuka T, Tsukamoto I. Insulin-dependent diabetes mellitus decreases osteoblastogenesis associated with the inhibition of Wnt signaling through increased expression of Sost and Dkk1 and inhibition of Akt activation. Int J Mol Med. 2011 Sep;28(3):455-62.

Hogan P, Dall T, Nikolov P, American Diabetes Association. Economic costs of diabetes in the US in 2002. Diabetes Care. 2003;26:917-932.

Holzhausen M, Garica DF, Pepato MT, Marcantonio EJr. The influence of short-term diabetes mellitus and insulin therapy on alveolar bone loss in rats. J Periodontol Res. 2004;39:188-193.

Horowitz MC, Xi Y, Wilson K, Kacena MA. Control of osteoclastogenesis and bone resorption by members of the TNF family of receptors and ligands. Cytokine Growth Factor Rev. 2001;12:9-18.

Hu W, Yeo JH, Jiang Y, Heo SI, Wang MH. The antidiabetic effects of an herbal formula composed of Alnus hirsuta, Rosa davurica, Acanthopanax senticosus and Panax schinseng in the streptozotocin-induced diabetic rats. Nutr Res Pract. 2013;7:103-8. 
International Diabetes Federation [internet]. Guideline on Oral Health for people with diabetes. Brussels: IDF, 2009 [cited 2012, jun 11]. Available from site http://www.idf.org/guidelines/diabetes-and-oral-health/guideline

Iseri H, Tekkaya AE, Öztan Ö, Biligiç S. Biomechanical effects of rapid maxillary expansion on the craniofacial skeleton, studied by the finite elemnt method. Eur J Orthod. 1998;20:347-356.

Ishijima M, Rittling SR, Yamashita T, Tsuji K, Kurosawa H, Nifuji A, et al. Enhancement of osteoclastic bone resorption and suppression of osteoblastic bone formation in response to reduced mechanical stress do not occur in the absence of osteopontin. J Exp Med. 2001;193:399-404.

Ishijima M, Tsuji K, Rittling SR, Yamashita T, Kurosawa H, Denhardt DT, et al. Osteopontin is required for mechanical stress-dependent signals to bone marrow cells. J Endocrinol. 2007;193:235-43.

Jandeleit-Dahm K, Rumble J, Cox AJ, Kelly DJ, Dziadek M, Cooper ME, et al. SPARC gene expression is increased in diabetes-related mesenteric vascular

Kos K, Wilding JP. SPARC: a key player in the pathologies associated with obesity and diabetes. Nat Rev Endocrinol. 2010;6:225-35.

Kossmehl P, Scho"nberger J, Shakibaei M, Faramarzi S, Kurth E, Habighorst B, et al. Increase of fibronectin and osteopontin in porcine hearts following ischemia and reperfusion. $J$ Mol Med. 2005;83:626-37.

Krishnan V, Davidovitch Z. Cellular, molecular, and tissue-level reactions to orthodontic force. Am J Orthod Dentofacial Orthop. 2006;129:469e.1-469e.32.

Kumar P, Londhe SM, Kotwal A, Mitra R. Prevalence of malocclusion and orthodontic treatment need in schoolchildren - An epidemiological study. Med J Armed Forces India. 2013 Oct;69(4):369-74.

Lappin DF, Eapen B, Robertson D, Young J, Hodge PJ. Markers of boné destruction and formation and periodontitis in type 1 diabetes mellitus. J Clin Periodontol. 2009 Aug;36(8):63441. 
Li X, Zhang L, Wang N, Feng X, Bi LJ. Periodontal ligament remodeling and alveolar bone resorption during orthodontic tooth moviment in rats with diabetes. Diabetes Technol Ther. 2010;12:65-73.

Lima SM, Grisi DC, Kogawa EM, Franco OL, Peixoto VC, Gonçalves-Júnior JF, Arruda MP, Rezende TM. Diabetes mellitus and inflammatory pulpal and periapical disease: a review. Int Endod J. 2013;46:700-9.

Liu R, Bal HS, Desta T, Krothapalli N, Alyassi M, Luan Q, Graves DT. Diabetes enhances periodontal bone loss through enhanced resorption and diminished bone formation. J Dent Res 2006;85:510-514.

Lohberger B, Kaltenegger H, Stuendl N, Payer M, Rinner B, Leithner A. Effect of cyclic mechanical stimulation on the expression of osteogenesis genes in human intraoral mesenchymal stromal and progenitor cells. Biomed Res Int. 2014;2014:1-10.

Lokulo-Sodipe K, Moon RJ, Edge JA, Davies JH. Identifying targets to reduce the incidence of diabetic ketoacidosis at diagnosis of type 1 diabetes in the UK. Arch Dis Child. 2014 May;99(5):438-42.

Lu Huafei, Kraut D, Gerstenfeld Lc, Graves DT. Diabetes interferes with the bone formation by affecting the expression of transcription factors that regulate osteoblast differentiation. Endocrinology. 2003;144:346-352.

Luan X, Ito Y, Holliday S, Walker C, Daniel J, Galang TM, Fukui T, Yamane A, Begole E, Evans C, Diekwisch TG. Extracellular matrix-mediated tissue remodeling following axial movement of teeth. J Histochem Cytochem. 2007;55:127-40.

Maia LG, Monini Ada C, Jacob HB, Gandini LG Jr. Maxillary ulceration resulting from using a rapid maxillary expander in a diabetic patient. Angle Orthod. 2011;81:546-50.

Meikle MC. The tissue, cellular, and molecular regulation of orthodontic tooth movement: 100 years after Carl Sandstedt. Eur J Orthod. 2006;28:221-140.

Mishima N, Sahara N, Shirakawa M, Ozawa H. Effect of streptozotocin-induced diabetes mellitus on alveolar bone deposition in the rat. Arch Oral Biol. 2002;47:843-849. 
Mitsui N, Suzuki N, Maeno M, Mayahara K, Yanagisawa M, Otsuka K, Shimizu N. Optimal compressive force induces bone formation via increasing bone sialoprotein and prostaglandin E(2) production appropriately. Life Sci. 2005;77:3168-82.

Motyl KJ, Botolin S, IrwinR, et al. Bone inflammation and altered gene expression. With type I diabetes early onset. J Cell Physiol. 2009;218:575-583.

Nascimento-Saba CC, Breitenbach MM, Rosenthal D. Pituitary-thyroid axis in short- and longterm experimental diabetes mellitus. Braz J Med Biol Res. 1997,30:269-74.

Nomura S, Takano-Yamamoto T. Molecular events caused by mechanical stress in bone. Matrix Biol. 2000;19:91-6.

Okamoto MM, Anhê GF, Sabino-Silva R, Marques FSF, Freitas HS, Mori RCT et al. Intensive insulin treatment induces insluin resistance in diabetic rats by imparing glucose metabolismrealted mechanisms in muscle and liver. J Endocrinol. 2011;211:1-10.

Okazaki R, Totsuka Y, Hamano K, Ajima M, Miura M, Hirota Y, Hata K, Fukumoto S, Matsumoto T. Metabolic improvement of poorly controlled noninsulin-dependent diabetes mellitus decreases bone turnover. J Clin Endocrinol Metab. 1997;82:2915-20.

Ong SC, Khanbay BS, McDonald JP et al. The novel use of three-dimensional surfasse models to quantify end visualized the immediate changes of the mid-facial skeleton following rapid maxillary expansion. Surgeon. 2013;13:1-7.

Ortiga-Carvalho TM, Curty FH, Nascimento-Saba CC, Moura EG, Polak J, Pazos-Moura CC. Pituitary neuromedin B content in experimental fasting and diabetes mellitus and correlation with thyrotropin secretion. Metabolism. 1997,46:149-53.

Oshiro T, Shiotani A, Shibasaki Y, Sasaki T. Osteoclast induction in periodontal tissue during experimental movement of incisors in osteoprotegerin-deficient mice. Anat Rec. 2002;266:21825.

Pacios S, Kang J, Galicia J, Gluck K, Patel H, Ovaydi-Mandel A, Petrov S, Alawi F, Graves DT. Diabetes aggravates periodontitis by limiting repair through enhanced inflammation. FASEB J. 2012;26:1423-30. 
Pingueiro-Okada, E.M. Efeito do laser de baixa potência após a expansão rápida da maxila, na ativação de regiões cerebrais relacionadas à nocicepção [mestrado]. Ribeirão Preto: Faculdade de Odontologia de Ribeirão Preto da Universidade de São Paulo; 2012.

Räkel A, Sheehy O, Rahme E, LeLorier J. Osteoporosis among patients with type 1 and type 2 diabetes. Diabetes Metab. 2008;34:193-205.

Reddy ER, Manjula M, Sreelakshmi N, Rani ST, Aduri R, Patil BD. Prevalence of Malocclusion among 6 to 10 Year old Nalgonda School Children. J Int Oral Health. 2013;5:49-54.

Roach HI. Why does bone matrix contain non-collagenous proteins? The possible roles of osteocalcin, osteonectin, osteopontin and bone sialoprotein in boné mineralisation and resorption. Cell Biol Int. 1994;18:617-28.

Roberts-Harry D, Sandy J. Orthodontics. Part11: Orthodontic tooth movement. Br Dent J 2004;196:391-394.

Rygh P, Moyers RE. Sistemas de forças e respostas dos tecidos às forças em ortodontia e ortopedia facial. In Moyers RE (Ed.). Ortodontia. Rio de Janeiro: Guarnabara Koogan S.A., 1991. p 258-280.

Sabino-Silva R, Freitas HS, Lamers ML, Okamoto MM, Santos MF, Machado UF. Na+glucose cotransporter SGLT1 protein in salivary glands: potential involvement in the diabetesinduced decrease in salivary flow. J Membrane Biol. 2009;228:63-69

Saito S, Shimizu N. Stimulatory effects of low-power laser irradiation on bone regeneration in midpalatal suture during expansion in the rat. Am J Orthod Dentofacial Orthop. 1997,111:52532.

Sawada M, Shimizu N. Stimulation of bone formation in the expanding mid-palatal suture by transforming growth factor-beta 1 in the rat. Eur J Orthod. 1996;18:169-79.

Shankaracharya M, Odedra D, Mallick M, Shukla P, Samanta S, Vidyarthi AS. Java-based diabetes type 2 prediction tool for better diagnosis. Diabetes Technol Ther. 2012;14:251-6.

Shaw JE, Sicree RA, Zimmet PZ. Global estimates of the prevalence of diabetes for 2010 and 2030. Diabetes Res Clin Pract. 2010;87:4-14. 
Silva JA, Lopes Ferrucci D, Peroni LA, de Paula Ishi E, Rossa-Junior C, Carvalho HF, et al. Periodontal disease-associated compensatory expression of osteoprotegerin is lost in type 1 diabetes mellitus and correlates with alveolar bone destruction by regulating osteoclastogenesis. Cells Tissues Organs. 2012;196:137-50.

Soboku K, Kikuchi T, Fujita S, Takeda H, Naruse K, Matsubara T, Noguchi T. Altered gene expression in gingival tissues and enhanced bone loss in rats with diabetes with experimental periodontitis. J Periodontol. 2014 Mar;85(3):455-64.

Sociedade Brasileira de Diabetes [internet]. Diretrizes da Sociedade Brasileira de Diabetes. Rio de Janeiro: SBD; 2009 jun [cited 2012]. Available from site http://www.diabetes.org.br/publicacoes/diretrizes-e-posicionamentos

Starup-Linde J. Diabetes, biochemical markers of bone turnover, diabetes control, and bone. Front Endocrinol (Lausanne). 2013;4:1-17.

Starup-Linde J, Eriksen SA, Lykkeboe S, Handberg A, Vestergaard P. Biochemical markers of bone turnover in diabetes patients--a meta-analysis, and a methodological study on the effects of glucose on bone markers. Osteoporos Int. 2014;25:1697-708.

Stuani AS. Influência do laser de baixa potência (GaAIAs) na remodelação óssea, após a disjunção da sutura palatina mediana em ratos Wistar [tese]. Rio de Janeiro: Faculdade de Odontologia da Universidade do Estado do Rio de Janeiro; 2008.

Stuani MBS. Remodelação óssea e expressão do gene RUNX2 , após expansãoo rápida de maxila, em ratos, com e sem aplicação do laser de baixa potêinca [livre docência]. Ribeirão Preto: Faculdade de Odontologia de Ribeirão Preto da Universidade de São Paulo; 2011.

Stuani AS.: Avaliação da remodelação óssea após disjunção da sutura palatine mediana experimental e a laserterapia de baixa potência, em ratos wistar [tese]. São Paulo: Faculdade de Ciências Farmacêuticas da Universidade de São Paulo; 2012.

Suzuki K, Kurose T, Takizawa M, Maruyama M, Ushikawa K, Kikuyama M, Sugimoto C, Seino $\mathrm{Y}$, Nagamatsu S, Ishida $\mathrm{H}$. Osteoclastic function is accelerated in male patients with type 2 diabetes mellitus: the preventive role of osteoclastogenesis inhibitory factor/osteoprotegerin (Ocif/Opg) on the decrease of bone mineral density. Diabetes Res Clin Pract. 2005;68:117125. 
Taddei SR, Moura AP, Andrade I Jr, Garlet GP, Garlet TP, Teixeira MM, da Silva TA. Experimental model of tooth movement in mice: a standardized protocol for studying bone remodeling under compression and tensile strains. J Biomech. 2012;45:2729-35.

Takano-Yamamoto T, Takemura T, Kitamura Y, Nomura S. Site-specific expression of mRNAs for osteonectin, osteocalcin, and osteopontin revealed by in situ hybridization in rat periodontal ligament during physiological tooth movement. $\mathrm{J}$ Histochem Cytochem. 1994;42:885-96.

Takenouchi H, Mayahara K, Arai Y et al. Longitudinal quantitative evaluation of the mid-palatal suture after rapid expansion using in vivo micro-CT. : Arch Oral Biol. 2014;59:414-23.

Tanaka S, Matsuzaka K, Sato D, Inoue T. Characteristics of newly formed bone during guided bone regeneration: analysis of cbfa-1, osteocalcin, and VEGF expression. J Oral Implantol. 2007;33:321-6.

Tanabe N, Wheal BD, Kwon J, Chen HH, Shugg RP, Sims SM, Goldberg HA, Dixon SJ. Osteopontin signals through calcium and nuclear factor of activated $T$ cells (NFAT) in osteoclasts: a novel RGD-dependent pathway promoting cell survival. J Biol Chem. 2011;286:39871-81.

Taneda S, Pippin JW, Sage EH, Hudkins KL, Takeuchi Y, Couser WG, Alpers CE. Amelioration of diabetic nephropathy in SPARC-null mice. J Am Soc Nephrol. 2003;14:968-80.

Terai K, Takano-Yamamoto T, Ohba Y, Hiura K, Sugimoto M, Sato M, et al. Role of osteopontin in bone remodeling caused by mechanical stress. J Bone Miner Res. 1999;14:839-49.

Tominaga M. Histopathological study on experimental tooth movement in the spontaneously diabetic rat. J Fukuoka Dent College. 2007;22(2):247-68.

Thrailkill KM, Liu L, Wahl EC, Bunn RC, Perrien DS, Cockrekk GE, Skinner RA, Hogue WR, Carver AA, Fowlkes, Aronson J, Lumpkin CKJr. Bone formation is impared in a model of type 1 diabetes. Diabetes. 2005;54:2875-2881.

Toms SR, Lemons JE, Bartolucci AA, Eberhardt AW. Nonlinear stress-strain behavior of periodontal ligament under orthodontic loading. Am J Orthod Dentofacial Orthop. 2002;122:174-9. 
Um YJ, Jung UW, Kim CS, Bak EJ, Cha JH, Yoo YJ, Choi SH. The influence of diabetes mellitus on periodontal tissues: a pilot study. J Periodontal Implant Sci. 2010;40:49-55.

Verna C, Dalstra M, Melsen B. The rate and the type of orthodontic tooth movement is influenced by bone turnover in a rat model. Eur J Orthod. 2000;22:343-52.

Villarino ME, Lewicki M, Ubios AM. Bone response to orthodontic forces in diabetic Wistar rats. Am J Orthod Dentofacial Orthop. 2011;139:S76-82.

Vinoth JK, Patel KJ, Lih WS, Seow YS, Cao T, Meikle MC. Appliance-induced osteopenia of dentoalveolar bone in the rat: effect of reduced bone strains on serum bone markers and the multifunctional hormone leptin. Eur J Oral Sci. 2013;121:517-24.

Wang W, Zhang X, Zheng J, Yang J. High glucose stimulates adipogenic and inhibits osteogenic differentiation in MG-63 cells through cAMP/protein kinase A/extracellular signalregulated kinase pathway. Mol Cell Biochem. 2010;338:115-22.

Watanabe K, Okamoto F, Yokoo T, lida KT, Suzuki H, Shimano H, Oshika T, Yamada $\mathrm{N}$, Toyoshima H. SPARC is a major secretory gene expressed and involved in thedevelopment of proliferative diabetic retinopathy. J Atheroscler Thromb. 2009;16:69-76.

Wild S, Roglic G, Green A, Sicree R, King H. Global Prevalence of Diabetes: Estimates for the year 2000 and projections for 2030. Diabetes Care. 2004;27:1047-1053.

Wessel D, Flügge UI. A method for the quantitative recovery of protein in dilute solution in the presence of detergents and lipids. Anal Biochem. 1984;138:141-3.

World Health Organization [internet]. Definition, Diagnosis and Classification of Diabetes Mellitus and its Complications. Part 1: Diagnosis and Classification of Diabetes Mellitus. Geneva: WHO,1999 [cited 2012, jun 11]. Available from site http://www.who.int/diabetes/currentpublications/en/

World Health Organization [internet]. Definition and diagnosis of diabetes mellitus and intermediate hyperglycemia: report of a WHO/IDF consultation. Geneva: WHO; 2006 [cited 2012, jun 11]. Available from site http://www.who.int/diabetes/publications/en/ 
Wu D, Li L, Yang M, Liu H, Yang G. Elevated plasma levels of SPARC in patients with newly diagnosed type 2 diabetes mellitus. Eur J Endocrinol. 2011;165:597-601.

Xu F, Ye YP, Dong YH, Guo FJ, Chen AM, Huang SL. Inhibitory effects of high glucose/insulin environment on osteoclast formation and resorption in vitro. J Huazhong Univ Sci Technolog Med Sci. 2013;33:244-9.

Yamaguchi M. RANK/RANKL/OPG during orthodontic tooth movement. Orthod Craniofac Res. 2009;12:113-9.

Zandi M, Miresmaeili A, Heidari A. Short-term skeletal and dental changes following boneborne versus tooth-borne surgically assisted rapid maxillary expansion: A randomized clinical trial study. J Craniomaxillofac Surg. 2014; 22:1-6.

Zhang L, Li X, Bi LJ. Alterations of collagen-I, MMP-1 and TIMP-1 in the periodontal ligament of diabetic rats under mechanical stress. J Periodontal Res. 2011;46:448-55.

Zhao N, Lin J, Kanzaki H, Ni J, Chen Z, Liang W, Liu Y. Local osteoprotegerin gene transfer inhibits relapse of orthodontic tooth movement. Am J Orthod Dentofacial Orthop. 2012;141:3040 .

Zhou J, Feng G, Zhou W, Ren A, Wu Y, Zhang D, Dai H. Expression of osteoprotegerin and receptor activator of nuclear factor $\mathrm{KB}$ ligand in root resorption induced by heavy force in rats. J Orofac Orthop. 2011;72:457-68. 


\section{Anexo}




\section{E R T I F I C A D O}

Certificamos que o trabalho (Protocolo $n^{\circ}$ 10.1.1026.53.6), intitulado "Avaliação do Processo de Remodelação Óssea Durante Aplicação de Biomecânica Ortopédica em Ratos Diabéticos Tipo 1 - Induzidos. Estudo delular e biomelecular", de autoria de Maria Bernadete Sasso Stuani, por estar de acordo com os Princípios Éticos na Experimentação Animal adotado pela Comissão de Ética no Uso de Animais (CEUA) do Campus de Ribeirão Preto - USP foi aprovado em reunião da CEUA de 07/10/2010.

This is to certify that the work (Protocol number 10.1.1026.53.6), entitled: "Avaliação do Processo de Remodelação Óssea Durante Aplicação de Biomecânica Ortopédica em Ratos Diabéticos Tipo 1 - Induzidos. Estudo delular e biomelecular", by Maria Bernadete Sasso Stuani, is in accordance with the Ethic Principles in Animal Experimentation adopted by Ethic Commission for the Use of Animals (CEUA) of the Campus of Ribeirão Preto - USP, and was approved in the meeting, October 07, 2010.

Ribeirão Preto, 19 de outubro de 2010

Evista Lute Panissi

Profa.Dra. Christie Ramos Andrade Leite Panissi

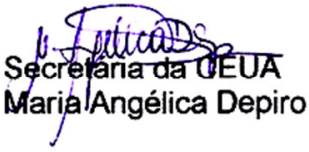

Av. Bandeirantes, 3900 - CEP 14040-900 - Ribeirão Preto - Såo Paulo Fone: (16) 36024469 - Fax: (16) 36337964 